\title{
LANGOAGE
}
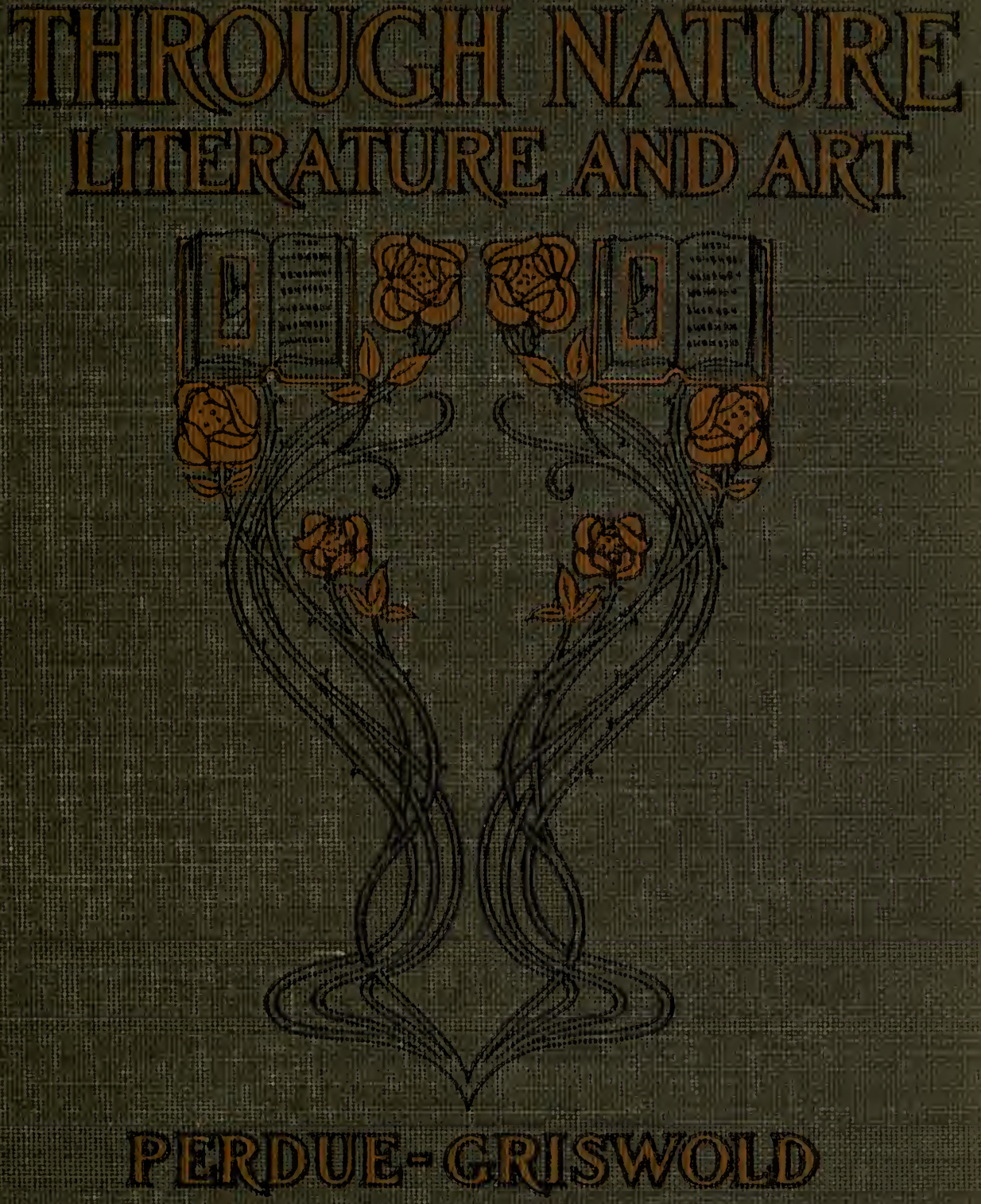


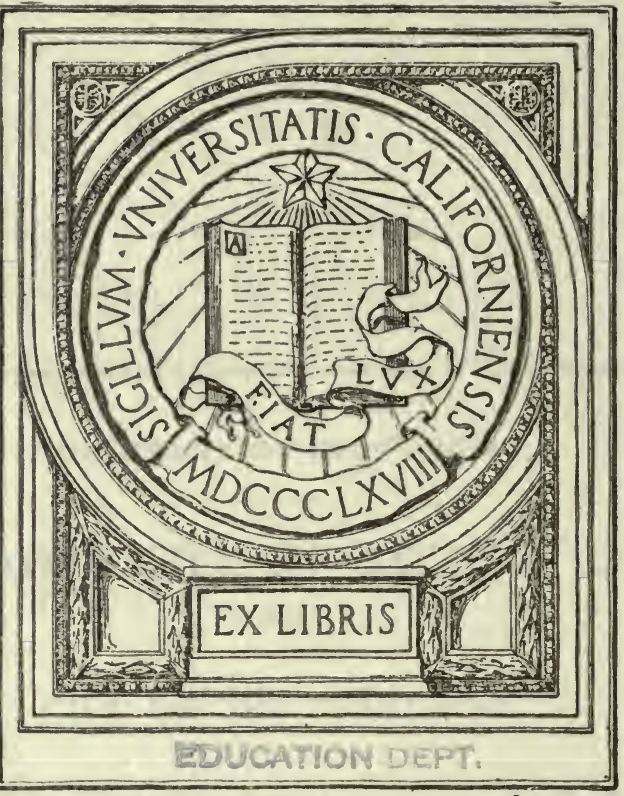

No. //C

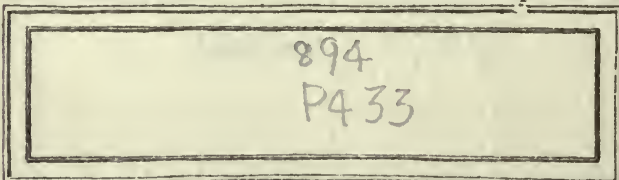



Digitized by the Internet Archive in 2007 with funding from Microsoft Corporation 


\section{LANGUAGE THROUGH}

NATURE, LITERATURE, AND ART

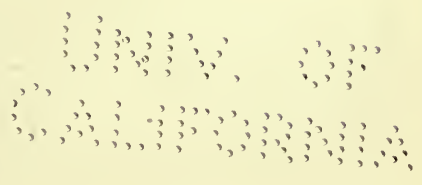




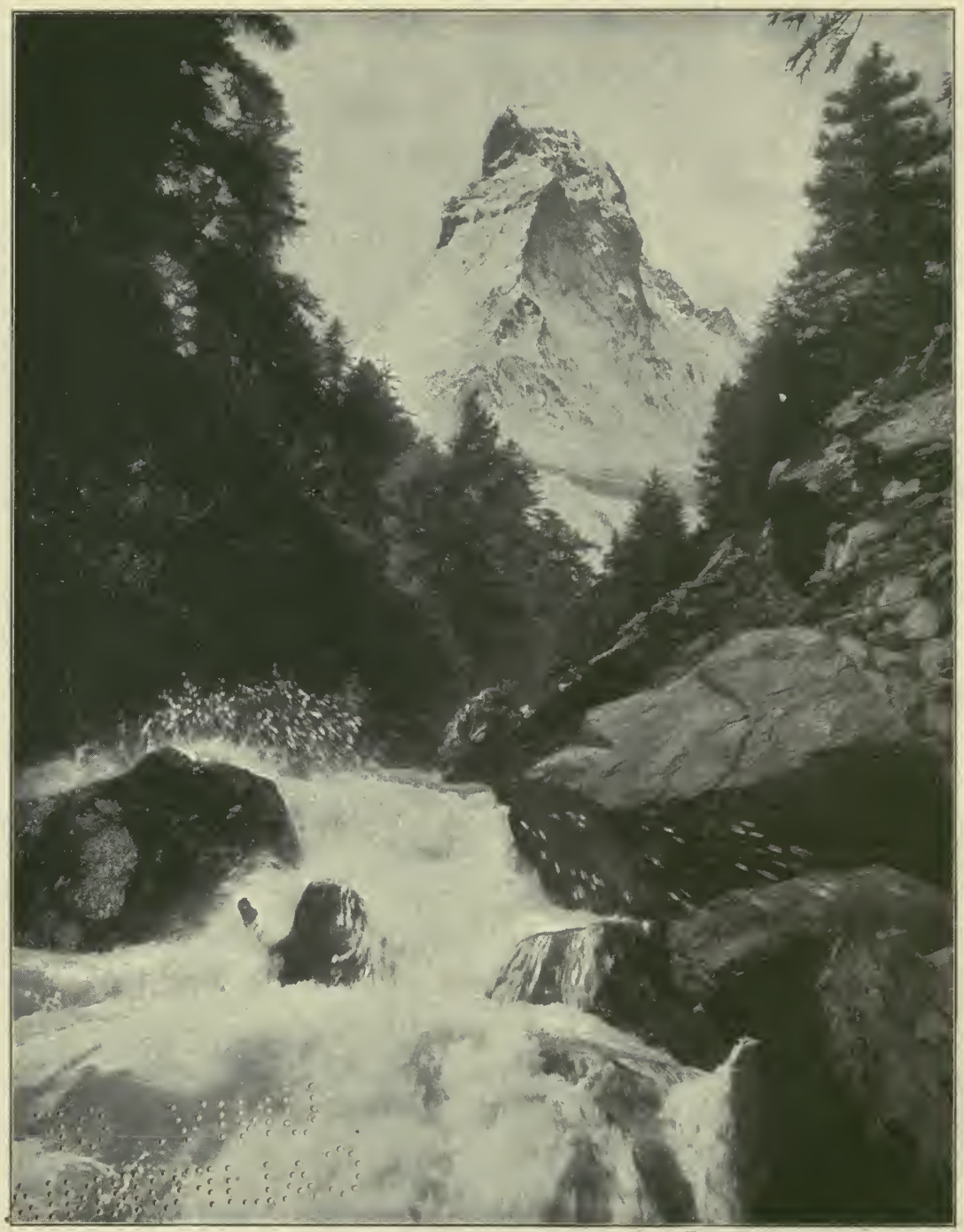




\section{LANGUAGE THROUGH}

NATURE, LITERATURE, AND ART

By H. AVIS PERDUE, of the Keith School, Chicago; and SARAH E. GRISWOLD, of the Chicago Normal School, Chicago."

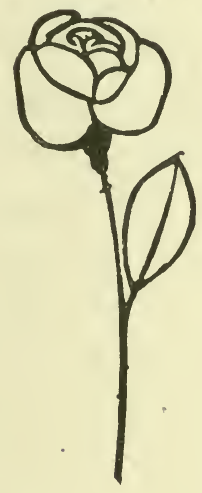

Chicago

New York Londosn

RAND, MCNALLY \& COMPANY 
Copyright, rooz,

By RÁND, MCNALLY \& COMPANY

EDUCATION DEPT

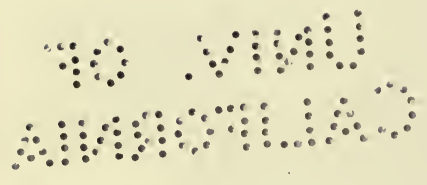




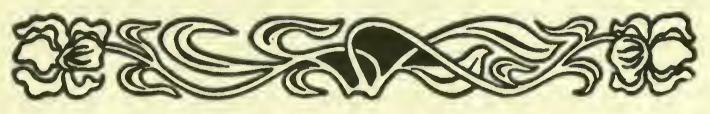

\section{AN INTRODUCTION}

THE first purpose of this book is to suggest subject-matter of genuine interest to children, and which of itself is worth while. A second purpose is to indicate such treatment of the subject-matter that the language used in the lessons will be the expression of real thought, and the formation of correct habits a natural result.

No claim is made to originality in subject-matter, but an effort has been made to select material which is suited to the changing conditions of the seasons and common to many localities.

Related lessons have been arranged in groups so as to arouse an interest in many phases of the subject and to broaden the child's experience. This grouping also demands natural repetition of vocabulary and consequent familiarity with its form. While lessons on nature study, stories, poems, and pictures have been so grouped, it has been the aim to treat each of these so that it would make its own legitimate appeal, and the peculiar value of each experience be gained by the children.

In developing each subject, many topics have been presented to meet varying conditions and interests. It is not expected that one pupil or class will necessarily follow all the lines indicated, but that those will be selected which appeal to past experience or which stimulate to further activity. In some cases "Suggested Work" has been outlined to point out possibilities of additional work for pupils or classes beyond

$$
541: 186^{5}
$$


the average in power, or to enable pupils to do more work in the subject without the teacher's direction. If such work is done, a report to the class will be interesting and valuable.

The purpose in calling for seat-work, such as cutting or drawing, in connection with some of the lessons, is to lead the class to review or think over the experiences more definitely, thus preparing for better language expression.

It is believed that the best results in oral expression come rather from a correct use of language than from learning definitions and rules. For this reason the questions and directions have been framed not only to stimulate thought, but to call for a full language response, thus giving an opportunity for the correction of errors and for training in right usage. Laws or rules governing uses of forms have been stated only after the children have had experiences that make those laws understood and when such statements might lead to care in further use of the same forms. The necessity for repetition in the formation of habits has been recognized and care taken to provide frequent opportunities for practice.

There is a well defined movement in favor of teaching form as an instrument of thought rather than as a thing of importance in itself. It is hoped that the material and suggestions in the following pages will be in accord with this movement.

The selections from Frank Dempster Sherman, Henry W. Longfellow, Celia Thaxter, John Burroughs, James Russell Lowe1l, and Edith M. Thomas are used by permission of, and special arrangement with, Houghton, Mifflin \& Company, publishers of the works of the authors named. For the use of other valuable copyrighted matter, thanks are extended to Little, Brown \& Company, D. Appleton \& Company, The Bowen-Merrill Company, and Mary Catherine Judd.

H. A. P. 


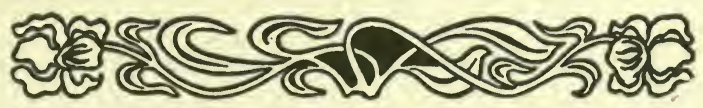

\section{THE TABLE OF CONTENTS}

PAGE

An Introduction . . . . . . . . . . . . . . . . . . . . 5

A List of the Plates . . . . . . . . . . . . . . . . . . . . I2

Lesson 1. Vacation Song . . . . . Frank Dempster Sherman $\mathrm{I}_{5}$

Lesson 2. Things to Remember When

Writing. . . . . . . . . . . . . . . . . 17

Lesson 3. September . . . . . . Helen Hunt Jackson . . . ${ }^{\circ}$

Lesson 4. Autumn . . . . . . . . . . . . . . . . . . . 22

Lesson 5. A Weather Record . . . . . . . . . . . . . . . 23

Lesson 6. Why the Ears of Wheat are Small:

A German Folklore Tale . . . . . . . . . . . 24

Lesson 7. Wheat . . . . . . . . . . . . . . . . . 26

Lesson 8. The Little Red Hen . . . . . . . . . . . . . . . 27

Lesson 9. A Picture Study . . . . . . . . . . . . . . . . 30

Lesson 10. The Story of a Great Artist:

Jean François Millet . . . . . . . . . . . . . 30

Lesson 11. Corn. . . . . . . . . . . . . . . . . . . . 33

Lesson 12. Mondamin . . . . . . Henry W. Longfellow . : 34

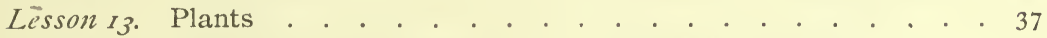

Lesson 14. Talking in Their Sleep . . . Edith M. Thomas . . . 38

Lesson 15. Monthly Summary . . . . . . . . . . . . . . . 40

Lesson 16. Seeds . . . . . . . . . . . . . . . . . . . . 40

Lesson 17. The Scattering of Seeds . . . . . . . . . . . . . . 4I

Lesson 18. How the Leaves Came Down. Susan Coolidge . . . . 42

Lesson 19. Contractions . . . . . . . . . . . . . . . . . . 45

Lesson zo. Observation of Trees . . . . . . . . . . . . . . . 46

Lesson 21. The Ant and the Grasshopper:

A Fable . . . . . . . . . . . . . . . . . . 47

Lesson 22. Insects . . . . . . . . . . . . . . . . . . . . 48

Lesson 23. The Sandpiper . . . . . Celia Thaxter . . . . 49

Lesson 24. Birds . . . . . . . . . . . . . . . . . . . . $5 \mathrm{I}$ 
Lesson 25. Hiawatha's Friends

Lesson 26. A Boy's Song .

Henry $W$. Longfellow . . 53

Lesson 27. Country Experiences

James Hogg.

Lesson 28. Squirrels

Lesson 29. Edwin Landseer

Lesson zo. The Market .

Lesson $3 x$. Parts of Plants Used as Food

60

Lesson 32. How Vegetables are Brought

to Market .

Lesson 33. Storing Fruits for Winter

John Burroughs

62

Lesson 34. The Farm in Autumn . .

Lydia A. Coonley

Lesson 35. A Picture Study

Lesson 36. A Famous Dutch Painter: Anton Mauve

Lesson 37. Summary of Weather Records

Lesson 38 . Evaporation of Water. .

Lesson 39. The Cloud .

Percy Bysshe Shelley

Lesson 4o. Condensation of Moisture

Lesson 4I. The Rainbow Fairies .

Lesson 42. Uses of Steam

Lizzie M. Hadley.

Lesson 43. The Frost

Hannah F. Gould.

Lesson 44. How Frost is Formed.

Lesson 45. Preparing for Winter.

Lesson 46. Wool.

. . . . . . . . 8o

Lesson 47. The Coat That Jack Wears .

Charlotte Perkins

Lesson 48. Weaving

Lesson 49. Woven Pictures .

Lesson 5o. Arachne

Lesson 5r. Hiawatha's Hunting .

Lesson 52. Uses of Coverings of Animals

Lesson 53. The Landing of the Pilgrims

Henry $W$. Longfellow . . 9I

Lesson 54. A Picture Study .

Lesson 55. George H. Boughton 
Lesson 59. The Story of the Wood .

Frank L. Stanton .

PAGE

Lesson 6o. Modes of Heating .

98

Lesson 6r. A Wood Fire

100

Lesson 62. Coal

Lesson 63. Other Uses of Coal

Lesson 64. Light

Lesson 65. Lighthouses.

Lesson 66. Ways of Lighting Dwellings .

Lesson 67. Winter Song

Lesson 68. Snowflakes

Lesson 69. A Wonderful Weaver

IOI

IOI

IO2

103

I03

. . . . . . 104

Emily Huntington Miller. 105

Adapted from Arabella Buckley

IO7

Lesson 7o. A Picture Study

George Cooper.

IO9

Lesson $7 r$. Svend Svendsen

Lesson 72. Ice.

Lesson 73. Up and Down

George Macdonald . . . I16

Lesson 74. The First Christmas Day

I I 7

Lesson 75. The First Christmas Tree .

Adapted from Honry van Dyke

I 20

Lesson 76. The Gift-Bearer

I 22

Lesson 77. Another Gift-Bearer .

123

Lesson 78. The New Year .

Alfred Lord Tennyson.

I 25

Lesson 79. Review of Things to Remember When Writing

Lesson 8o. The Seasons .

Lesson 8r. Telling Time

Lesson 82. The Clock

132

Lesson 83. Aurora: A Greek Story .

132

Lesson 84. A Picture Study

Lesson 85. Guido Reni

134

Lesson 86. Hiawatha's Sailing

Lesson 87. Ways of Traveling

Henry $W$. Longfellow

Lesson 88. Some Animals Used in Traveling

Lesson 89. A Useful Animal .

Lesson go. A Picture Study 
Lesson 92. Monthly Summary

PAGE

Lesson 93. The Village Blacksmith

I 44

Lesson 94. The Blacksmith's Work

I 45

Lesson 95. Iron . .

Lesson 96. Uses of Iron

Lesson 97. Vulcan the Smith

Lesson 98. Precious Metals

150

Lesson 99. Other Metals

152

Lesson roo. The Golden Touch

I 52

Lesson 101. Abraham Lincoln

Lesson 102. Brick .

Lesson 103. Stone.

Lesson 104. Preparation of Stone for Building .

I 59

160

Lesson ro5. A Picture Study

Lesson 106. Michael Angelo Buonarotti

I6I

Lesson 107. George Washington

162

Lesson 108. Red Riding Hood

Lesson 109.

A Thrifty Blue Jay .

John G. Whittier

162

Lesson rro. Henry Wadsworth Longfellow . John Burroughs

Lesson III. Monthly Summary

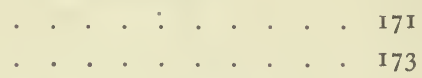

Lesson IIz. Hiawatha's Home

Henry W. Longfellow . 174

Lesson 113 . Woods and Their Uses

176

Lesson 114. Preparation of Wood for Use

177

Lcsson 115. Ventilation

179

Lesson I16. The Wind's Work

I 79

Lesson 117 . The Foolish Weather-Vane .

180

Lesson II8. The Four Winds .

Henry W. Longfellowe . 183

Lesson 119. The Weather .

I 86

Le'sson 120. The Sun and the Wind

I 87

Lesson 121. A Picture Study .

I 88

Lesson 122. Paul Joseph Constantine Gabriel 190 Lesson 123. A Laughing Chorus

Lesson 124. Monthly Summary

Lesson 125

Wild Geese .

Celia Thaxter 
PAGE

Lesson 128. The Tree

Lesson 129. Spring Flowers

Lesson 1зо. Birds

Lesson ${ }^{3}{ }^{\prime}$. The Lesson in Nest-Building

Lesson 132. Insect Life .

Lesson 133 . Bees

Lesson 134. Blossoms and Bees

Lesson 135. King Solomon and the Bee

Lesson 136. Spring Work on the Farm

Lesson 137. A Picture Study .

Lesson 138 . Spring

Lesson 139. Cotton

Lesson 140. Seeds.

Lesson 14I. Gardens .

Lesson 142. The Story of a Seed .

Lesson 143. Farm Animals

Lesson 144. Farm Products

Lesson 145. Roads

Lesson 146. A Picture Study

Lesson 147. The Boy and the River: A Fable

Lesson 148 .

Lesson 149.

Lesson 150 . June Days .

Lesson 151. The Gladness of Nature

Lesson 152. A Picture Study

Lesson 153. Jean Baptiste Camille Corot .

Lesson 154. The Voices of Nature: A Myth of Finland
Rain in Summer.

Björnstjerne Martinius

Björnson . . . . 198

199

200

2or

203

John Burroughs . . . 204

207

207

209

2 IO

212

$2 \mathrm{I} 3$

$2 \mathrm{I} 4$

214

George Macdonald . . 215

217

219

220

220

222

Henry $W$. Longfellow . 223

226

James Russell Lowell . 227

William Cullen Bryant 229

230

232

Mary Catherine Judd . 234

A Pronouncing Index . 


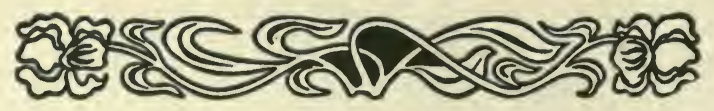

\section{A LIST OF THE PLATES}

PAGE

The Matterhorn . . . . . . . . . . . . . Frontispiece From a Swiss photograph.

The Murmuring Brook . . . . . . . . . . . . . . . . 14

The North Fork of the Blackwater.

The Gieaners

From a painting by Jean François Millet.

The Lonely Road .

From a painting by Anton Mauve.

The Pilgrims.

From a painting by George H. Boughton.

A Winter Sunrise.

From a painting by Svend Svendsen.

At the Watering Trougi .

From a painting by Pascal A. Dagnan-Bouveret.

The Young Sculptor . . . . . . . . . .
From a sculpture by Michael Angelo Buonarotti.

The Windmill

From a painting by Paul J. C. Gabriel.

The Sower

From a painting by Jexn François Millet.

A Woman Chumnisg

From a painting by Jean François Millet.

LANDSCAPE

From a painting by Jean B. Camille Corot. 
"And thit oux life, exempt from publtx yaunt, find tongues in txees, books in the xumning bxorkt, fexmons in ftomes, and good in evexything."

[ flokspexe.] 
$\because \div \div$

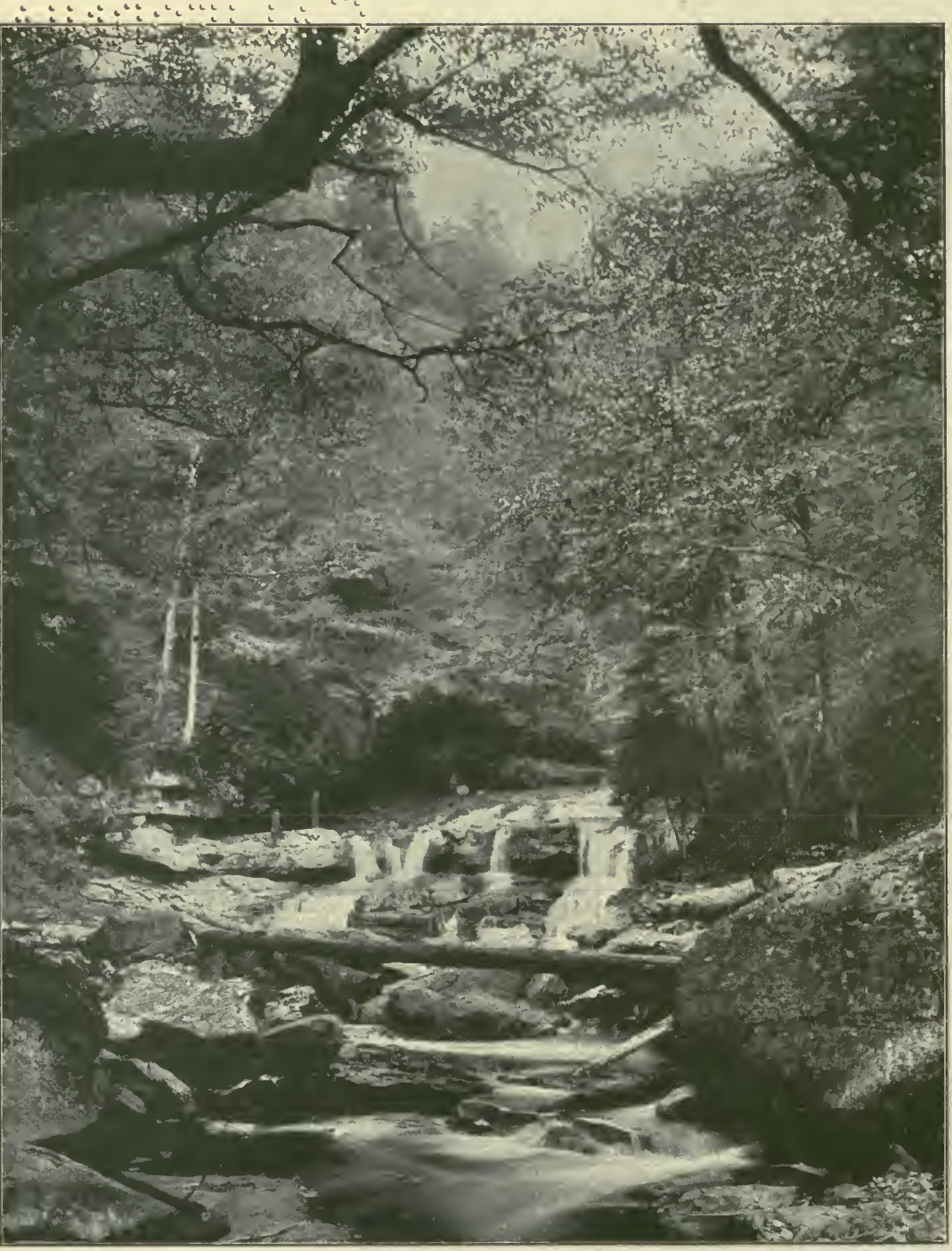




\section{L:ANGUAGE}

\section{THROUGH NATURE, LITERATURE, AND ART}

\section{Lesson I \\ VACATION SONG}

WHEN study and school are over, How jolly it is to be free,

Away in the fields of clover,

The honey-sweet haunts of the bee!

Away in the woods to ramble,

Where, merrily all day long,

The birds in the bush and bramble

Are filling the summer with song.

Away in the dewy valley

To follow the murmuring brook,

Or sit on its bank and dally

Awhile with a line and a hook. 
Away from the stir and bustle,

The noise of the town left behind:

Vacation for sport and muscle,

The winter for study and mind.

There's never a need to worry,

There's never a lesson to learn,

There's never a bell to hurry,

There's never a duty to spurn.

So play till the face grows ruddy

And muscles grow bigger, and then

Go back to the books and study;

We'll find it as pleasant again.

- Frank Dempster Sherman.

Here we are at school again after a vacation.

Let us hear what you have been doing.

Where did you spend your vacation?

Tell about the work that you did and the games that you played.

Describe the game you liked best.

If you went away from home, give an account of your trip.

Where did you go?

How did you travel?

Who went with you?

Tell about the most interesting thing you saw.

Make a picture showing which of the things mentioned in the poem you would most like to do. 


\section{Lesson 2}

\section{THINGS TO REMEMBER WHEN WRITING}

Every sentence should begin with a capital letter.

Names of months and days of the week should begin with capital letters.

Every statement should end with a period.

Every question should end with a question mark.

When writing we sometimes wish to shorten words. We write Sept. for September, Tues. for Tuesday, Ill. for Illinois. A word so shortened is called an abbreviation.

Every abbreviation should be followed by a period.

\section{ABBREVIATIONS}

Here are some of the most common abbreviations. You will often need to use them when writing.

Jan. for January.

Feb. " February.

Mar. “ March.

Apr. " April.

(no abbreviation) May.

" " June.

Mon. for Monday.

Tues. "Tuesday.

Wed. “ Wednesday. (no abbreviation) July.

Aug. for August.

Sept. “ September.

Oct. " October.

Nov. " November.

Dec. “ December.

Sun. for Sunday.

Av. for Avenue.

Co. " County, or Company.

Dr. " Doctor.
Mr. for Mister.

Mrs. " Mistress.

St. " Street.
Thurs. for Thursday.

Fri. " Friday.

Sat. “ Saturday. 
IS

Language Through Nature

Chicago, Ill.,

Sept.10, 1901.

Dear Miss Adams:

I will tell you about my vacation and what $l$ did in it. As soon as school closed my sister and l left Chicago and after a short and pleasant trip arrived at our grandfather's farm.

The farm is a large one. There are orchards of pear, peach, plum, apple, cherry and quince trees, a vineyard and acres of eurrant bushes.

grandfather has a large barn yard. In it there is a machinery house, a corn-erib and granary and a big barn. The loft of the barn holds thirty tons of hay. There are thirty stalls for horses and cows and there is a shed that will hold a hundred sheep.

Almost the first place I visited was the hayfield where I had fine rides on the loads of hay. When the men were mowing the hay a little brown rabbit jumped out and the fox-terrier, Josie, caught it and gave it to grandpa. 


\section{Sister and I had pets at the farm.}

I had a dog whose name was Beautry and a eat whose name was Rajah and a snow-white hen we ealled Silver. Sister had two little chickens named Midget and Goldry.

One week we went eamping in the woods on the shore of a beautiful little lake. We slept in the tents but eooked and ate and lived out of doors. We eaught fish in the lake and broiled them over the hot eoals. We roasted potatoes and eorn and everrything tasted good. At night we sat around the fire and told stories and sang songs until it was time to go to sleep.

We had a very happy summer and hope that next year we ean go again to grandfather's farm.

your loving pupil.

Donald Morrison.

The line that tells where the letter was written is called the heading.

The line that tells when the letter was written gives the date.

The line that tells to whom the letter was written is called the salutation. 
The line that says good-bye is called the ending.

The name of the writer is called the signature.

Read the ending of the letter and the signature.

What is told in the body of this letter?

Study the punctuation and arrangement of the heading, date, salutation, ending, and signature of this letter.

Notice where the first sentence of the body of the letter begins.

Write a letter to your teacher telling about something that you enjoyed during your vacation.

Arrange the ending and signature of your letter carefully.

Use the letter on page I 8 for a model in form.

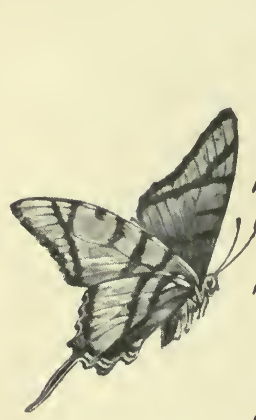

\section{Lesson 3}

\section{SEPTEMBER}

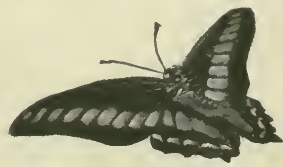

HE golden-rod is yellow;

The corn is turning brown;

The trees in apple orchards

With fruit are bending down.

The gentian's bluest fringes

Are curling in the sun;

In dusty pods the milkweed

Its hidden silk has spun.

The sedges flaunt their harvest,

In many a meadow nook;

And asters by the brook-side

Make asters in the brook. 
From dewy lanes at morning

The grapes' sweet odors rise;

At noon the roads all flutter

With yellow butterflies.

By all these lovely tokens

September days are here,
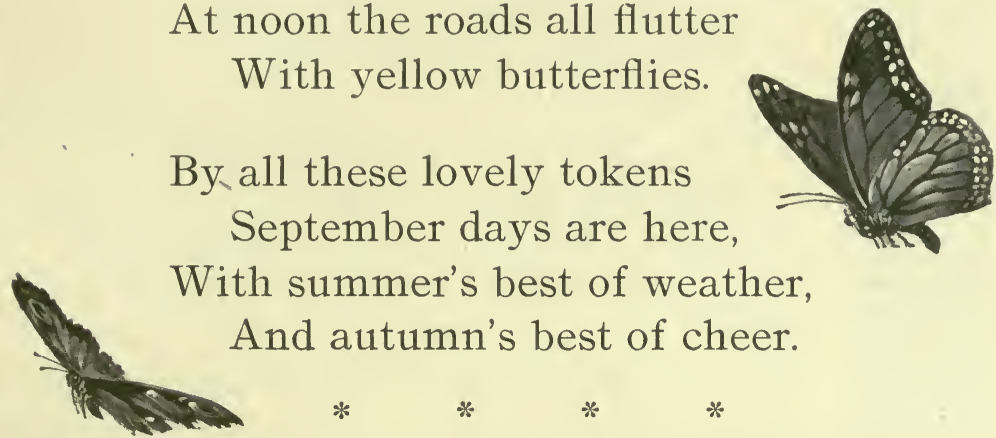

And autumn's best of cheer.

* $\quad * \quad * \quad *$

- Helen Hunt Jackson.

What flowers are mentioned in the poem? If you have seen any of these flowers growing, tell when and where.

Name the places that you think of when you read the first stanza of the poem called "September."

Describe the milkweed pod, and tell what it contains.

What is the "hidden silk" of the milkweed?

What are "sedges," and what is "their harvest"?

How do "asters by the brook-side make asters in the brook"?

Tell what fruit grew in or near the lane described in the fourth stanza. When do fruits have sweet odors?

Tell when butterflies are seen, and where.

Name all the "lovely tokens" that tell of September days. If you like this description of autumn, you may tell why.

Learn the poem.

Make a picture to illustrate the first stanza. 


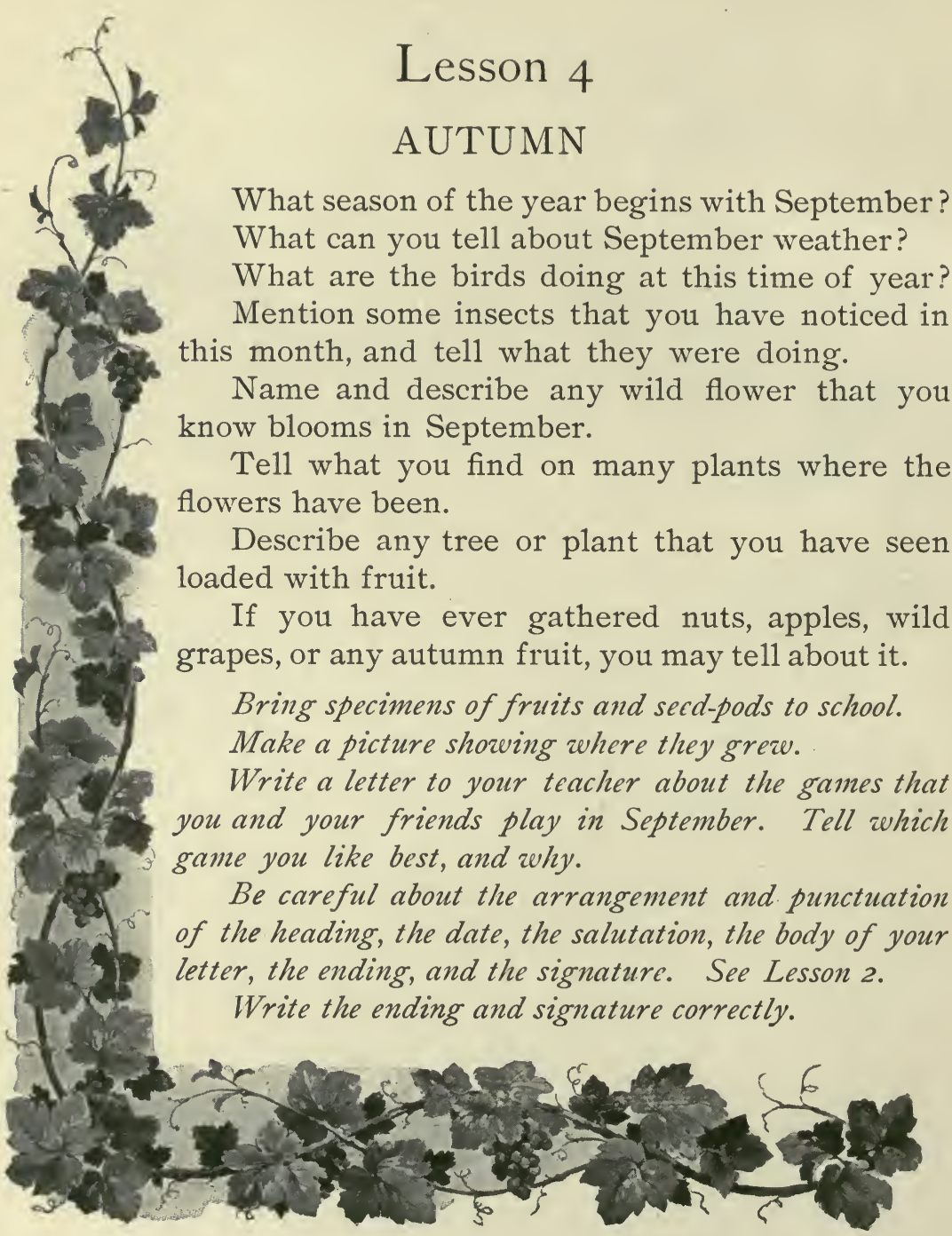




\section{Lesson 5 \\ A WEATHER RECORD}

Each day you may write about the weather. Save all of these papers.

Write about all the things'named below, making a complete sentence for cach. Be careful to use capital letters and punctuation marks correctly.

Tell the name of the day and the date.

What is the temperature for to-day?

Was there dew or frost this morning?

If the sky is cloudy, tell how the clouds look.

Did rain or snow fall to-day?

From what direction does the wind blow?

Tell at what time the sun rises and sets?

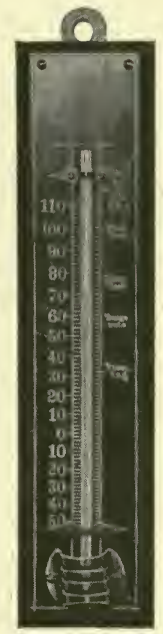

How we tell the temperature

\section{THE SUN'S TRAVELS}

THE sun is not a-bed, when I

1 At night upon my pillow lie;

Still round the earth his way he takes,

And morning after morning makes.

While here at home, in shining day,

We round the sunny garden play,

Each little Indian sleepy-head

Is being kissed and put to bed. 


\section{Lesson 6}

WHY THE EARS OF WHEAT ARE SMALL A German Folklore Tale

T ONG ago the King of the Fields and Forests walked about on this earth. All nature, from the lowliest plant by the roadside to the giant oak of the forest, rejoiced in his presence, for the great King loved and cared for them all.

In those days the stalks of wheat were very tall and the grains of wheat grew up and down the stalks from top to bottom. On every stalk there were hundreds of plump, brown kernels.

One day, when the golden wheat was ready for the sickle, a mother and her little son were walking through a wheat field and came to a pool of water in the pathway. The child amused himself by breaking off great stalks of wheat and throwing them into the water. The mother stood near without saying one word to stop him.

Just then the King of the Fields and Forests came by and saw the boy wasting the wheat. He saw also the careless mother. The King was angry and called out in a voice like thunder, "Is this the way you mortals waste the precious grain that is 
given you for food? From this time on nothing shall grow upon the wheat stalks."

Then the woman and all who heard him were terrified. They fell upon their knees before the King and begged for mercy. "O King, spare us," they cried. "If you do not give us back the wheat we shall perish from hunger."

When the King saw their grief he pitied them and said, "I will answer your prayer. But to punish you for your wastefulness the wheat kernels shall henceforth grow only at the top of the stalk."

And this is why the ears of wheat are small.

What does the story say about the King of the Fields and Forests? How did the wheat grow at first?

Where were the little boy and his mother walking?

Who came that way, and what did he see?

How did he feel, and what did he say?

What did the people do when they heard the King's words? What happened after this?

Tell this story in your own words.

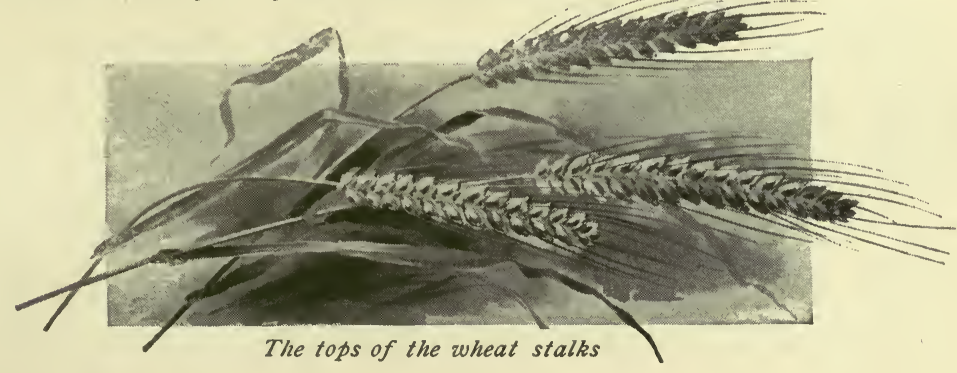




\section{6

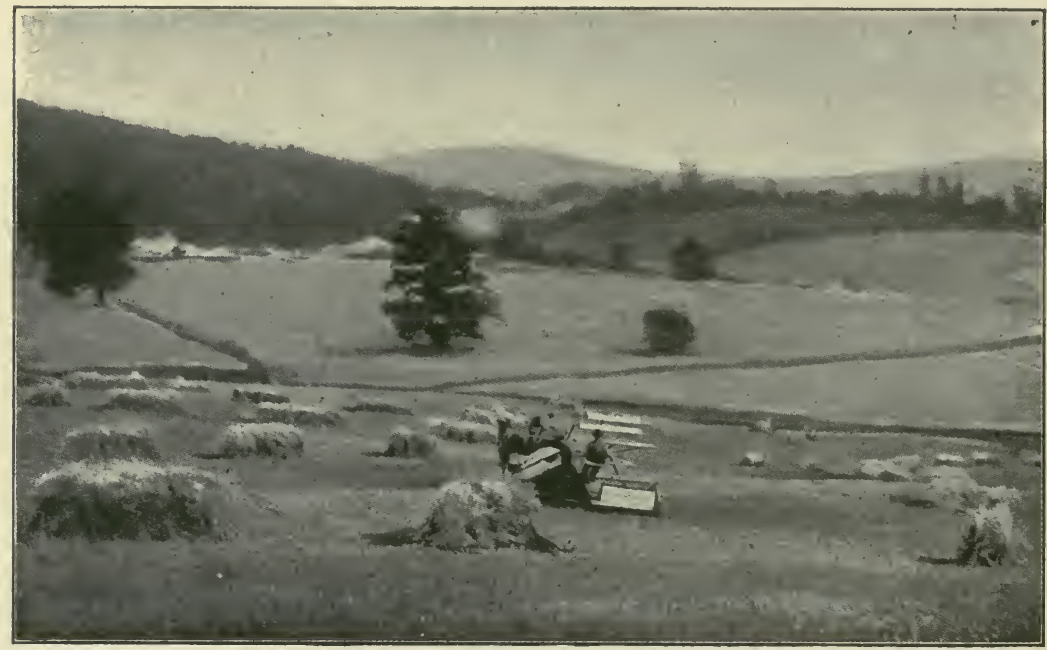

Harvesting wheat

\section{Lesson 7}

\section{WHEAT}

Have you ever seen wheat growing? Tell how it looked. What color is the ripe wheat? Describe the harvesting. In what month is wheat generally harvested? What part of the wheat is used for food? Tell all you can about the threshing of wheat. Of what use is the straw? How is it stored? What is made from the wheat kernels? How is it made? Tell of a way in which you could crush the wheat. What are the fine and coarse parts of the crushed wheat each called? For what is each used?

How is flour put up for market?

Name some foods which are made from wheat. 


\section{Lesson 8 \\ THE LITTLE RED HEN}

THE little red hen found a grain of wheat, and 1 she said, "Who will plant this wheat?"

The rat said, "I won't." The cat said, "I won't," and the pig said, "I won't."

"I will then," said the little red hen, and she did.

When the wheat was ripe she said, "Who will' take this wheat to the mill to be ground into flour?"

The rat said, "I won't." The cat said, "I won't," and the pig said, "I won't."

The little red hen said, "I will then," and she did.

When she came back with the flour she said, "Who will make this flour into bread?"

The rat said, "I won't." The cat said, "I won't," and the pig said, "I won't."

The little red hen said; "I will then," and she did.

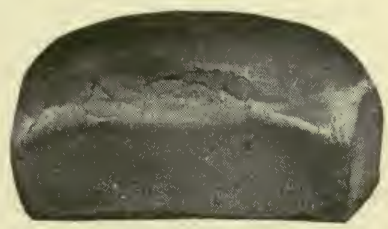

"Who will eat this bread?"

When the bread was done the little red hen said, "Who will eat this bread?" 
The rat said, "I will." The cat said, "I will," and the pig said, "I will."

The little red hen said, "No, you won't, for I am going to do that myself," and she did.

Tell what the little red hen found.

What did she say when she had found it?

What did the rat, the cat, and the pig then say?

Tell just what the hen said in reply.

When the exact words of another are repeated they are called a direct quotation.

Read the quotation that tells what the hen said when the grain was ripe.

Quote what the rat, the cat, and the pig each said in reply.

Quote what the hen then answered.

Notice the marks (") before and after the quotations. These are called quotation marks, and are always used in writing a direct quotation.

Every direct quotation begins with a capital letter.

Every direct quotation is separated from the rest of the sentence by commas.

A quotation is usually separated from the part of the sentence that follows by a comma. When the quotation is a question it is followed by a question mark.

Give the quotation that tells what the hen said when she came from the mill.

Give the sentence quoting what each animal said in reply to the question.

Quote what the hen then said.

Write a sentence quoting what the hen said when the bread was done. 
Write the rest of this story, quoting the exact words of the rat, the cat, the pig, and the hen, placing the quotation marks correctly. Begin each sentence with a capital letter.

Use the period after each statement.

Use the question mark after each question.

Mr. Henry W. Longfellow said:

"If you would have a thing well done you must do it yourself; you must not leave it to others."

Copy and learn this quotation.

Write a letter to your mother or your teacher telling her how wheat grows, how it is harvested and prepared for our use.

Arrange and punctuate your letter carefully.

Remember to bcgin each sentence with a capital letter.

Fold your letter neatly and inclose it in an envelope. Address it to your mother or teacher, following the model given below.

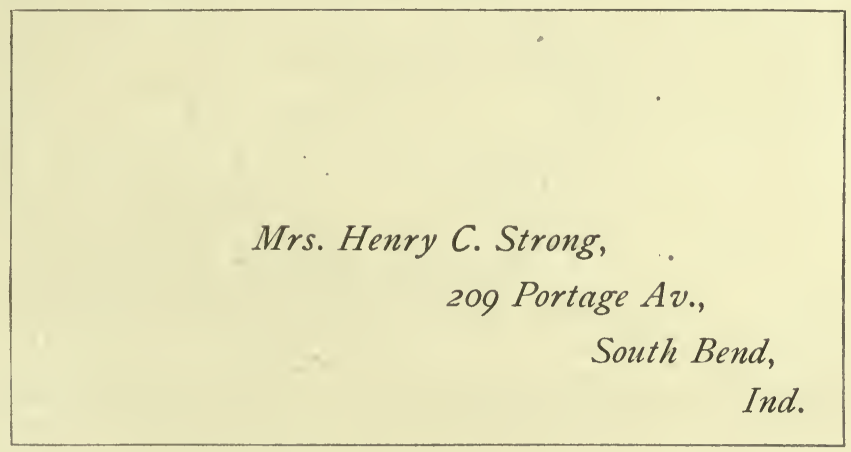

In writing the address be careful to place the period after each abbreviation, and a comma after the name of the person, the street, and the city. 


\section{Lesson 9 \\ A PICTURE STUDY}

Study carefully the picture of "The Gleaners." All the grain has been cut. In the background we can see some of it in stacks, and people still at work.

In the foreground are three peasant women. What are they doing?

Describe their dress and tell how they carry the gathered grain.

For what do you think they will use the grain when gathered? How will it be stored?

If you think their work is hard, tell why.

Do you think these women have done much of this kind of work? Tell why.

For whom do you think they are working?

This is a copy of a famous picture. The artist must have seen something in these workers about which he wished to tell everyone. What do you think it was?

Who was the artist?

Tell what you like best about this picture.

\section{Lesson 10}

\section{THE STORY OF A GREAT ARTIST}

$A^{\text {LMOST a hundred years ago, in a little French }}$ A village, there lived a boy whose name was Jean François Millet. His father was a farmer, a hard-working man, but one who loved music and 


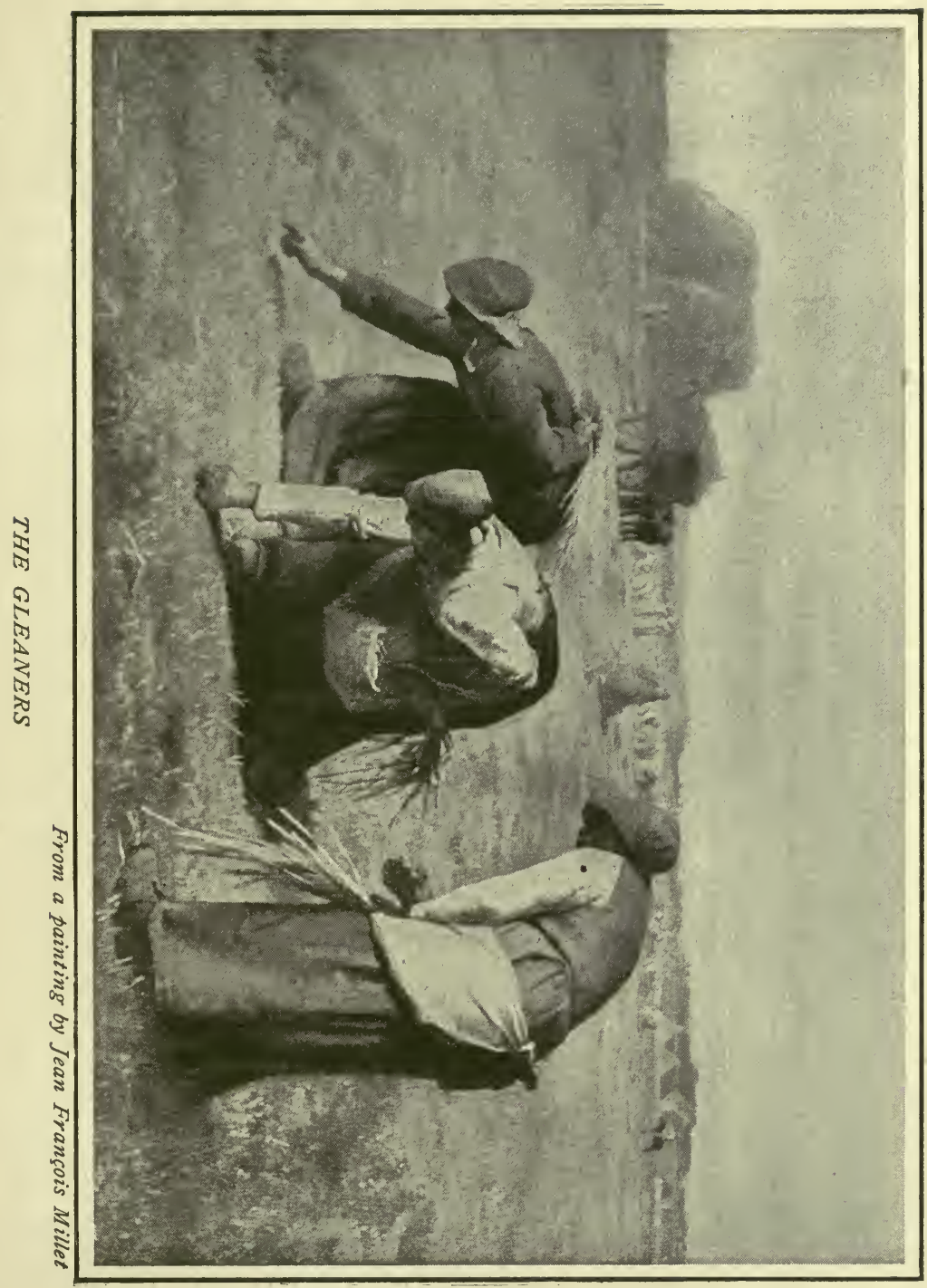


nature. While the father and mother were busy with farm work, the children were cared for by their grandmother. She was a good, wise, and energetic woman. Early in the morning she would come to the bedside of her little grandson to waken him. She would say gently, "Wake up, my little François. You don't know how long the birds have been singing the glory of God."

Jean François liked to draw pictures. One day he saw an old man walking along the road. The boy made a picture of him and drew the bent figure so well that his father was delighted. His eyes sparkled with pride and joy, and he exclaimed, "Our boy must be an artist!" So Jean François was sent away to the city of Cherbourg to learn to paint pictures. The boy worked hard, and, as his father had hoped, became a great artist.

Millet painted many pictures. They are nearly all of men and women working at just such tasks as he had often seen his own father and mother doing in his village home. He liked to wander in the green fields and silent woods. He watched the men and women as they toiled. He noticed every change in the sky and the lights and shadows among the trees. 
The picture about which you have been talking is a copy of one of Millet's best pictures. In this book you will find copies of some of the artist's other pictures, in each one of which he tells us a story taken from every-day life. The more we study the picture the more of truth and beauty we see in it. This is true of every good picture. So, as you look at a picture, try to find out what the artist meant to have it say.

Tell all you can of Millet and his work.

\section{Lesson I I \\ CORN}

If you have seen Indian corn growing, you may tell how it looks.

Why is it called Indian corn?

What part of the corn is used for food?

In what way is unripe corn used?

Describe the ripe corn.

How is it harvested?

What use is made of the leaves and the stalks?

How does the farmer store the ears of corn?

Tell all you know about the ways in which the whole corn is used.

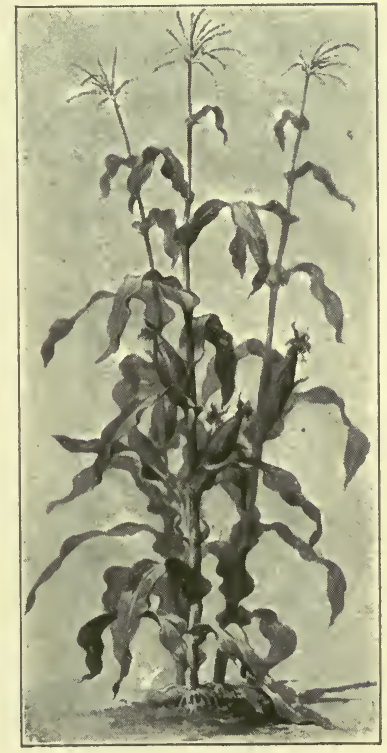

Indian corn 


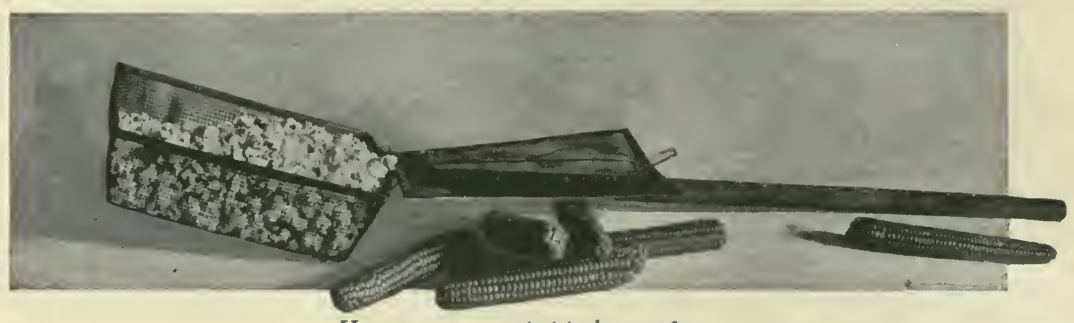

Have you ever popped corn?

How did the Indians cook corn?

Did they grind it, and if so, how?

Write answers to the following questions, beginning each statement with a capital letter and ending each with the proper mark.

If you have ever husked corn, tell where.

If you have ever roasted corn, tell when.

If you have ever shelled corn, tell how.

If you have ever popped corn, tell about it.

Make pictures to illustrate any of the things spoken of in this lesson.

\section{Lesson I 2 MONDAMIN}

SUMMER passed, and Shawondasee $\infty$ Breathed his sighs o'er all the landscape,

From the South-land sent his ardors, Wafted kisses warm and tender; And the maize-field grew and ripened, Till it stood in all the splendor 
Of its garments green and yellow,

Of its tassels and its plumage,

And the maize-ears full and shining

Gleamed from bursting sheaths of verdure.

Then Nokomis, the old woman,

Spake, and said to Minnehaha:

" 'Tis the Moon when leaves are falling;

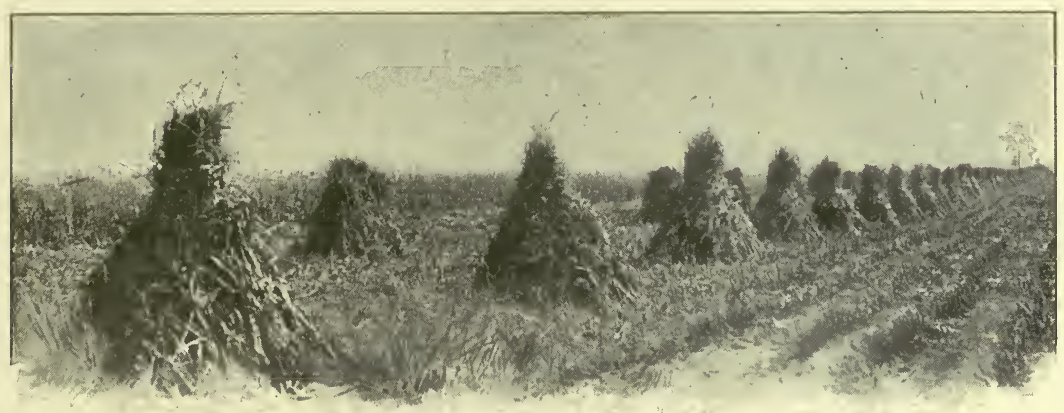

"And the maize is ripe and ready"

All the wild rice has been gathered, And the maize is ripe and ready;

Let us gather in the harvest,

Let us wrestle with Mondamin, Strip him of his plumes and tassels, Of his garments green and yellow!"

And the merry Laughing Water Went rejoicing from the wigwam, With Nokomis, old and wrinkled, And they called the women round them, 


\section{Language Through Nature}

Called the young men and the maidens, To the harvest of the cornfields, To the husking of the maize-ear.

$$
\text { -From "Hiawatha," by Henry W. Longfellow. }
$$

When Shawondasee sighs, what wind do we say is blowing? What is meant by the "maize-field"?

What did Nokomis mean when she said, "'Tis the moon when leaves are falling"?

How long a time did the Indians mean by a "moon"?

Quote all that Nokomis said to Minnehaha.

Tell how you think the Indians wrestled with Mondamin.

By what other names do you know Mondamin?

Who gathered the harvest and husked the ears of maize?

Who does most of the work in our harvesting?

The Indians gathered wild rice and corn.

We harvest wheat, oats, rye, and corn for food.

The corn has to be husked, shelled, and ground into flour.

The wheat has to be harvested, threshed, and ground into flour.

In the above sentences you find lists of things harvested.

You also find lists of things done to some of the grains.

Such a list of words is often called a series.

In writing a series a comma is placed after each word except the last.

In the next lesson you may need to write sentences containing a series of words.

Remember to use the comma correctly. 


\section{Lesson I 3 \\ PLANTS}

Name as many parts of a plant as you can.

Name some plants on which you have never seen flowers or seeds.

Which parts are found in all plants?

Mention some plants that have many seeds.

Name some that have but few.

What happens to many plants when the cold weather comes?

If you know of any plant that is not entirely killed by the cold weather, you may tell about it.

What part is kept alive?

Compare the number of seeds on such plants with the number on plants that are entirely killed.

Tell in what part of these plants the growth seems to have been greatest.

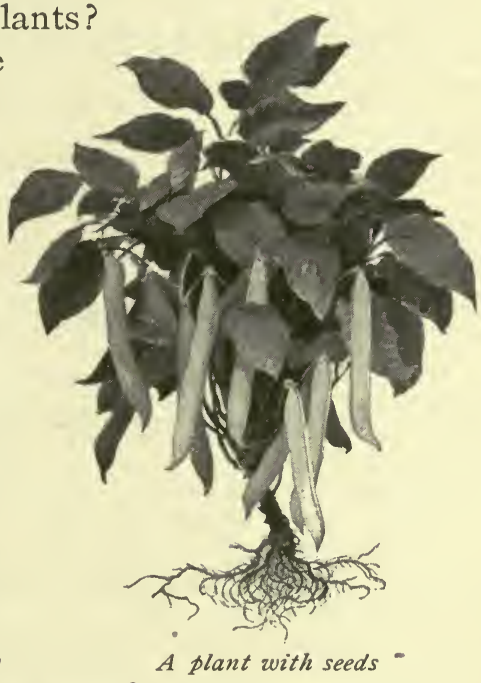

From what do beets and turrips grow?

How shall we get seeds from such plants as these?

We will plant some of these roots in a box, and keep them to see what happens.

Make pictures of the roots of plants that have secd, as the mustard or bean plants.

Make pictures of the roots of some plants that have made no seed, as the beet or turnip. 


\section{Lesson I 4}

\section{TALKING IN THEIR SLEEP}

"YOU think I am dead,"

1 The apple-tree said,

"Because I have never a leaf to show-

Because I stoop,

And my branches droop,

And the dull gray mosses over me grow!

But I'm all alive in trunk and shoot;

The buds of next May

I fold away-

But I pity the withered grass at my root."

"You think I am dead,"

The quick grass said,

"Because'I have parted with stem and blade!

But under the ground

I am safe and sound

With the snow's thick blanket over me laid.

I'm all alive and ready to shoot,

Should the spring of the year

Come dancing here-

But I pity the flower without branch or root." 
"You think I am dead,"

A soft voice said,

"Because not a branch or root I own!

I never have died,

But close I hide

In a plumy seed that the wind has sown.

Patient I wait through the long winter hours;

You will see me again -

I shall laugh at you then,

Out of the eyes of a hundred flowers."

- Edith M. Thomas.

In the first stanza what is talking?

Quote all that the tree says.

What words in the stanza are not a part of the quotation? These words divide the quotation.

When a quotation is divided each part is inclosed in quotation marks.

Find the divided quotations in the second and third stanzas.

Name all the things that make the tree seem to be dead.

Where does the tree say it is alive?

What has it folded away? Tell what it pities, and why.

What part of the grass is safe and sound?

How is it protected? When will it grow?

What does the grass pity, and why?

From what does the voice come that answers the grass?

When will the seeds show that they are alive?

Name some of the flowers that laugh at us in the spring, and tell which one you like best. 


\section{Lesson I 5 \\ MONTHLY SUMMARY}

Look over the month's papers about the weather.

In this lesson recall what you have learned about the use of capital letters and punctuation marks. Use them correctly in the following exercise, by writing a new paper, answering these questions in complete sentences:

How many clear days have we had this month?

How many cloudy days?

On how many mornings has there been dew?

On how many frost?

How many rainy days have there been in the month?

Tell how many days the wind has blown from each direction. From which direction has it blown most?

Is the weather growing colder or warmer?

Tell about any change you notice in the length of day. Make a picture of the landscape and keep it with this paper.

\section{Lesson 16 SEEDS}

Where do we get the seeds to plant in our gardens?

Name some seeds which are gathered in the fall and saved for planting. Name some seeds which we never gather.

Name plants found in the garden of which the seeds were not planted. How did they come there?

Mention ways in which seeds are sometimes carried far from the plant on which they grew.

Name and describe seeds carried in each of these ways. If you write about these seeds use the comma in each series. 


\section{Lesson I 7 \\ THE SCATTERING OF SEEDS}

What seeds are shown at the top of this page?

How are such seeds scattered?

Tell of other seeds that are scattered in the same way.

Are seeds ever carried great distances in this manner?

What do you know about maple seeds? What other seeds are like them? If you have seen them whirling in the air, tell when and where.

Name some seeds that have little hooks with which they catch hold of passers by.

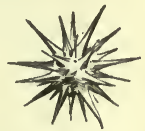

Tell about any of them that you have seen carried on the covering of animals or on the clothing of people.

Mention some seeds that birds like for food.

How do birds help in scattering such seeds?

Do you know of any seeds that will float?

Imagine an island without plants, in the midst of the sea. Describe all the ways in which seeds might be carried to it so that in time plants would be growing there.

Write a letter to some one at home telling about what you have liked best in your study of plants and seeds.

In writing and addressing your letter, follow the models on pages I 8 and 29.

Use capital letters correctly and punctuate carefully.
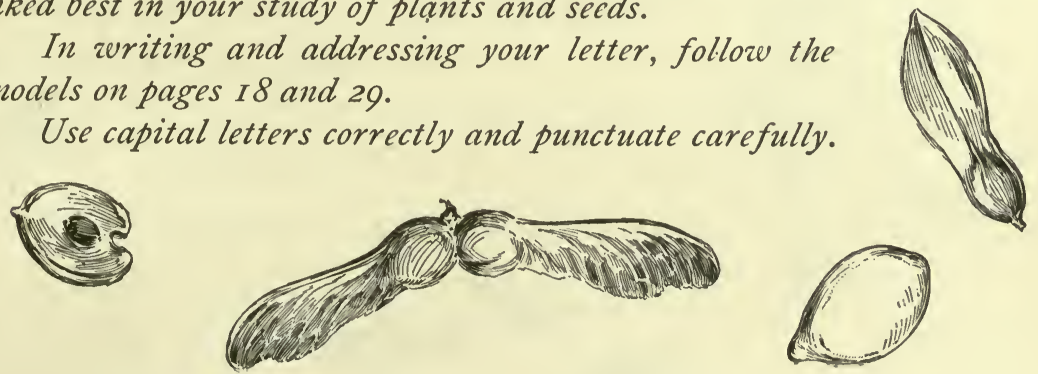


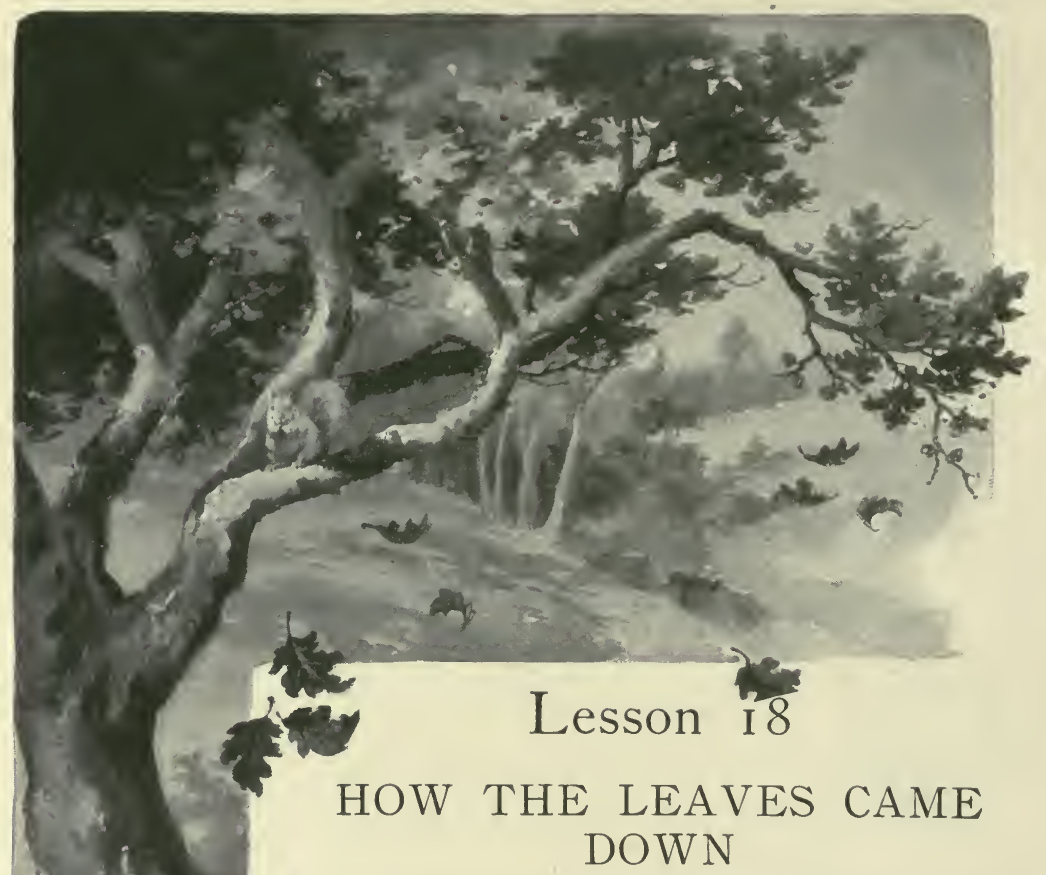

J'LL tell you how the leaves came 1 down :

The great Tree to his children said, Y "You're getting sleepy, Yellow and 1. Hus Brown,

(1) Yes, very sleepy, Little Red,

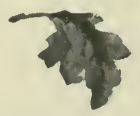

Exiv It is quite time you went to bed."

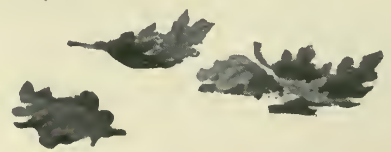


“Ah!” begged each silly, pouting leaf,

"Let us a little longer stay;

Dear Father Tree, behold our grief,

'Tis such a very pleasant day

We do not want to go away.'

So, just for one more merry day

To the great Tree the leaflets clung,

Frolicked and danced and had their way,

Upon the autumn breezes swung,

Whispering all their sports among :

"Perhaps the great Tree will forget

And let us stay until the spring,

If we all beg and coax and fret."

But the great Tree did no such thing;

He smiled to hear their whispering.

"Come, children all, to bed," he cried;

And ere the leaves could urge their prayer

He shook his head, and far and wide,

Fluttering and rustling everywhere,

Down sped the leaflets through the air.

I saw them; on the ground they lay,

Golden and red, a huddled swarm,

Waiting till one from far away, 
White bed-clothes heaped upon her arm, Should come to wrap them safe and warm.

The great bare Tree looked down and smiled. "Good-night, dear little leaves," he said;

And from below each sleepy child Replied "Good-night," and murmured, "It is so nice to go to bed."

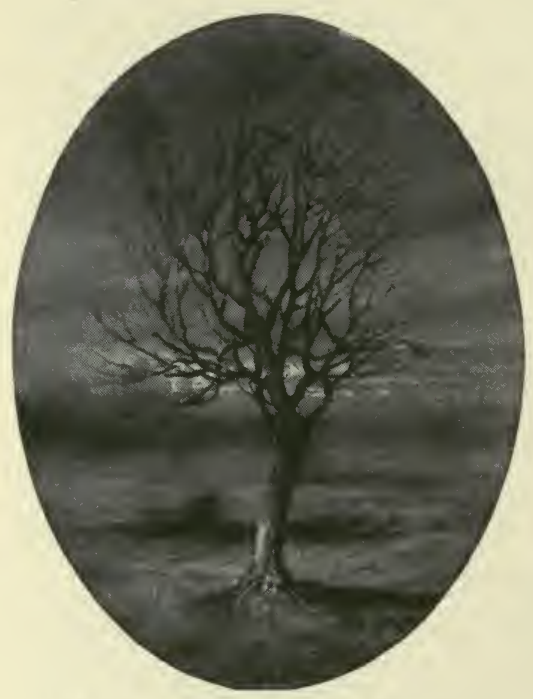

"The bare Tree looked down and smiled"

- Susan Coolidge.

What is this poem about?

Quote what the great tree said to his children.

Tell the names of some of these children and why they. were so called.

Why did the tree say they ought to go to bed?

How did the leaves behave?

Tell what they said.

How long were the leaves allowed to stay and what did they do?

Quote what they whispered "all their sports among."

What did the great tree do? How did it send the leaves to bed?

Where have you seen such a bed?

Who was to bring the bed-clothes and of what were they made? 
What do you think made the great tree smile as he looked down on his children?

Quote all that the leaves said when the tree bade them good-night.

Bring a twig to school from a tree that you know.

Teach me, Father, how to be,
Kind and patient as a tree.

-Edrvin Markham.

\section{Lesson I 9 \\ CONTRACTIONS}

What two words could you use in place of the first word of the poem, "How the leaves came down"?

How is $I$ will shortened to make I'll?

A word made from two words by omitting a letter or letters is called a contraction.

The mark (') which you see where the letters are omitted is called an apostrophe.

Find another contraction in the first stanza.

Tell from what words it is made.

In writing contractions, the apostrophe is always used in place of the letter or letters omitted.

Find a contraction in the second stanza, and tell from what words it is made.

Here are some of the common contractions. Tell from what words each is made:

$\begin{array}{llll}\text { I'll } & \text { we've } & \text { don't } & \text { isn't } \\ \text { I've } & \text { you're } & \text { didn't } & \text { haven't } \\ \text { I'm } & \text { can't } & \text { it's } & \text { they'll }\end{array}$




\section{$46 \quad$ Language Through Nature}

\section{Lesson 20}

\section{OBSERVATION OF TREES}

Tell of some trees that you have seen losing their leaves this fall. Why are the leaves falling?

What do you remember about the trees last spring, and how the leaves came?

How do you think these trees will get leaves next spring?

Tell of anything you have noticed on the twigs besides the leaves or marks where leaves have been.

What sometimes happens to twigs in

Describe the ways in which buds a re from cold.

We shall put some twigs in water and watch to see what happens.

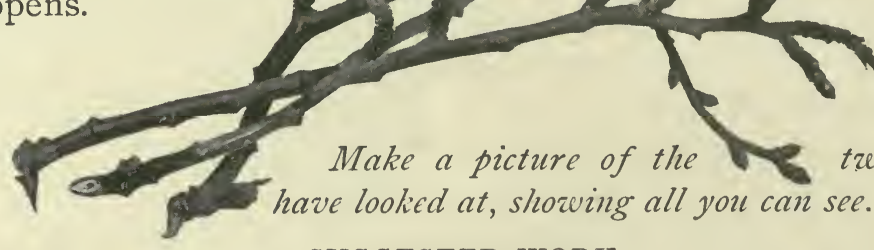

SUGGESTED WORK

If the class would like to study insects and their ways, they can easily fit up a place in which specimens can be kept alive and properly cared for.

Get or make a box about three feet long, two and one-half feet wide, and eight or ten inches deep. Nail in each corner an upright about three or four feet long, and two inches wide by one inch thick. Strengthen by sticks connecting the tops of the uprights. Fasten netting above and around the sides of this frame.

In the box place a pan of water, some soil and sods of grass, a few growing plants, and some twigs stuck in the sod.

The class now have a cage in which they can put the insects they wish to observe. Grasshoppers, butterflies, caterpillars, beetles, and other specimens of insect life can be thus kept and studied. 


\section{Lesson 2 I}

\section{THE ANT AND THE GRASSHOPPER A Fable}

T a grassy field one bright summer's day a 1 Grasshopper was hopping about, chirping and singing. An Ant passed by, bearing with great difficulty a grain of wheat which he was taking to his home.

"Come and chat with me instead of toiling like that," said the Grasshopper.

"I can't," said the Ant; "I'm helping to lay up food for the winter, and I advise you to do the same."

"Why trouble yourself about winter?" said the Grasshopper. "Winter is a long way off and we have plenty of food at present."

But the Ant went on with his work. When the winter came the Grasshopper had no food and found himself dying of hunger, while the Ant had an abundant store of grain which he had collected during the summer. Then the Grasshopper thought: "I have learned that it is best to prepare for the days of need." 


\section{Language Through Nature}

What contractions are used in this story?

Write this story in your own words.

In writing the title of a story, the first word, and every important word, begin with a capital letter.

Notice that the word I is always written as a capital letter.

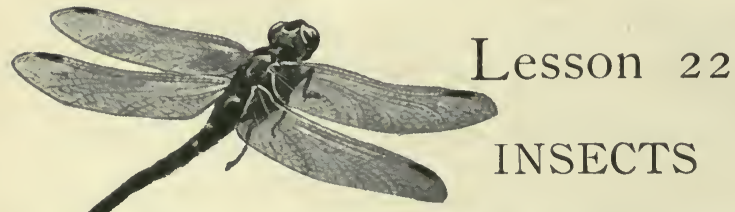

What insects have you noticed this summer?

What was each one doing?

Tell what you can about the food of each.

Describe one of these insects.

Describe any of their nests that you know about.

Which of these insects do you see at this time of year?

Where do they get food now?

From what insect do we take a part of its store for food and how can it spare so much?

Tell what the caterpillars are doing now.

Have you ever looked on the ground under boards and stones?

What insects did you find there?

Make pictures showing.homes of caterpillars, ants, and bees.
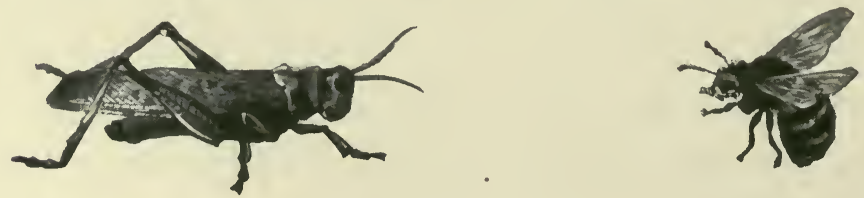


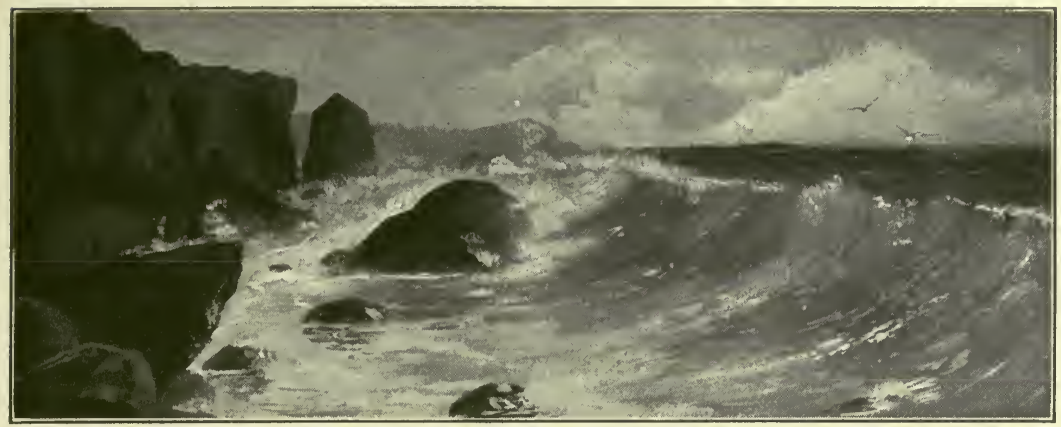

"The wild wind raves, the tide runs high"

\section{Lesson 23 \\ THE SANDPIPER}

AROSS the narrow beach we flit,

A One little sandpiper and I,

And fast I gather, bit by bit,

The scattered driftwood bleached and dry.

The wild waves reach their hands for it,

The wild wind raves, the tide runs high,

As up and down the beach we flit,-

One little sandpiper and I.

Above our heads the sullen clouds

Scud black and swift across the sky;

Like silent ghosts in misty shrouds

Stand out the white lighthouses high. 
Almost as far as eye can reach

I see the close-reefed vessels fly,

As fast we flit along the beach,-

One little sandpiper and I.

I watch him as he skims along,

Uttering his sweet and mournful cry.

He starts not at my fitful song,

Or flash of fluttering drapery.

He has no thought of any wrong;

He scans me with a fearless eye.

Stanch friends are we, well tried and strong,

The little sandpiper and I.

Comrade, where wilt thou be to-night

When the loosed storm breaks furiously?

My driftwood fire will burn so bright!

To what warm shelter canst thou fly?

I do not fear for thee, though wroth

The tempest rushes through the sky:

For are we not God's children both,

Thou, little sandpiper, and I?

- Celia Thaxter. 
About whom does this poem tell?

Describe the place where they are, and tell about the weather.

For what is driftwood being gathered?

Tell how the sandpiper behaves, and why.

What does the one gathering driftwood say of the bird? Why does she call the bird "comrade"?

What questions are asked of the bird?

What in the poem tells you that the bird will be safe?

Make a picture of the scene described in the poem.

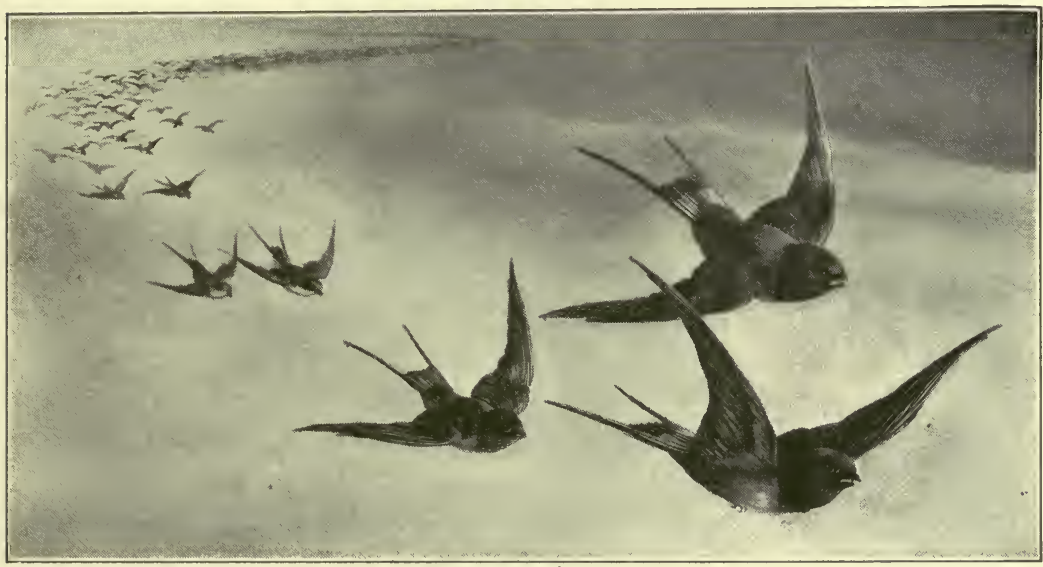

The birds' journey

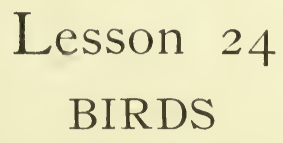

Mention some birds that have been here all summer.

What have they been doing?

Tell all you can about their food. 
What do you know about their food supply at this season?

How will they get food this winter?

What birds have you seen going away?

Tell where they are going and how they can find food there at this season.

How do you think they find their way?

Where and why do they stop on their journey?

When will they come back here?

What birds, if any, stay here all winter?

What do they eat? How are they kept warm?

Name any other animals that get thicker coats for winter.

Make a picture of our landscape at this season.

Make a picture showing how you think the landscape looks in the place to which the birds go.

If you write about birds be careful to use capital letters and punctuation marks correctly.

Remember how a comma is used in writing a series.

\section{GOOD-BYE TO SUMMER}

THE brown birds are flying like leaves through the sky,

The flow'rets are cailing, "Dear birdlings, goodbye!"

The bird voices falling, so soft from the sky, Are answ'ring the flow'rets, "Dear playmates, good-bye." 


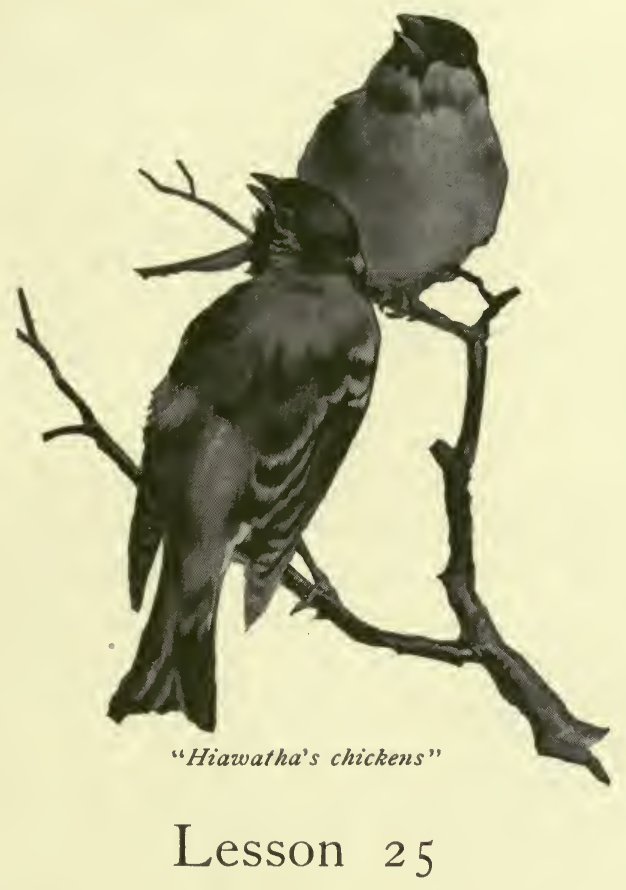

HIAWATHA'S FRIENDS

THEN the little Hiawatha

1 Learned of every bird its language,

Learned their names and all their secrets,

How they built their nests in Summer,

Where they hid themselves in Winter,

Talked with them whene'er he met them,

Called them "Hiawatha's Chickens." 
Of all beasts he learned the language, Learned their names and all their secrets, How the beavers built their lodges, Where the squirrels hid their acorns, How the reindeer ran so swiftly, Why the rabbit was so timid.

Talked with them whene'er he met them, Called them "Hiawatha's Brothers."

$$
\text { * * * * }
$$

- From "Hiawatha," by Henry W. Longfellow.

What contraction do you find in this poem?

Out of what two words is this contraction made?

Tell what Hiawatha called the birds and the beasts.

How do you think he came to know them so well? beasts.

Tell what you know about the language of birds and

What are some of their secrets?

If you know any secrets of birds or animals you may tell about them.

\section{Lesson 26 \\ A BOY'S SONG}

WHERE the pools are bright and deep, Where the gray trout lies asleep,

Up the river and o'er the lea,

That's the way for Billy and me. 
Where the blackbird sings the latest,

Where the hawthorn blooms the sweetest,

Where the nestlings chirp and flee,

That's the way for Billy and me.

Where the mowers mow the cleanest,

Where the hay lies thick and greenest;

There to trace the homeward bee,

That's the way for Billy and me.

Where the hazel bank is steepest,

Where the shadow falls the deepest,

Where the clustering nuts fall free,

That's the way for Billy and me.

-James Hogg (The Ettrick Shepherd).

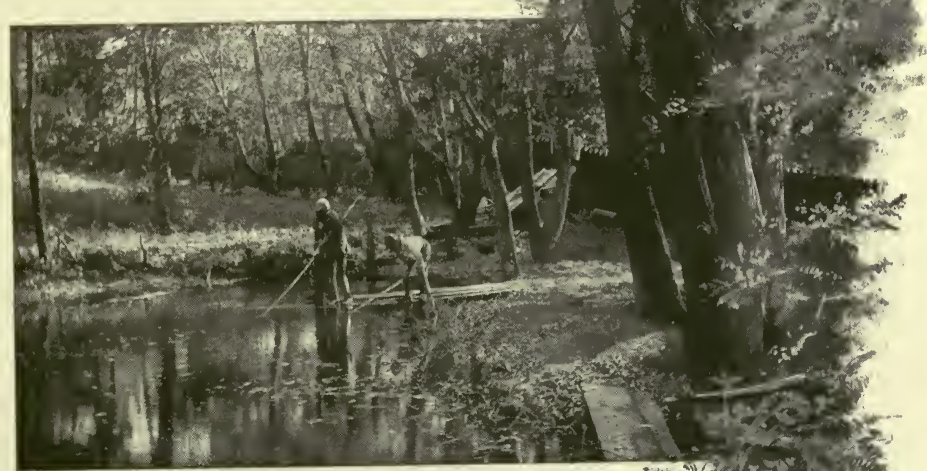

"Where the pools are bright and deep" 


\section{Language Through Nature}

The first word of every line of poetry is written with a capital letter.

The name of a person, when written, always begins with a capital letter.

You may copy this poem. Notice the title carefully.

In writing the title, and in copying the poem, be sure to use capital letters correctly.

In writing the contractions do not forget the apostrophe. Place all the punctuation marks where they belong. Make a picture to illustrate the stanza you like best.

\section{HAPPY THOUGHT}

The world is so full of a number of things, I'm sure we should all be as happy as kings.

-Robert Louis Stevenson.

\section{Lesson 27 \\ COUNTRY EXPERIENCES}

Have you ever been fishing? Tell where.

Have you ever heard birds sing? Tell when.

If you have seen hay made, describe how it was done.

If you have been nutting, tell what kind of nuts you gathered, and where you found them. What did you do with them?

Give an account of any other interesting experiences you have had when in the country.

\section{SUGGESTED WORK}

Bring specimens of nuts to school. Learn their names, and on what and where each kind grows. Plant some in the yard, mark the place; in the spring see what you will find there. 


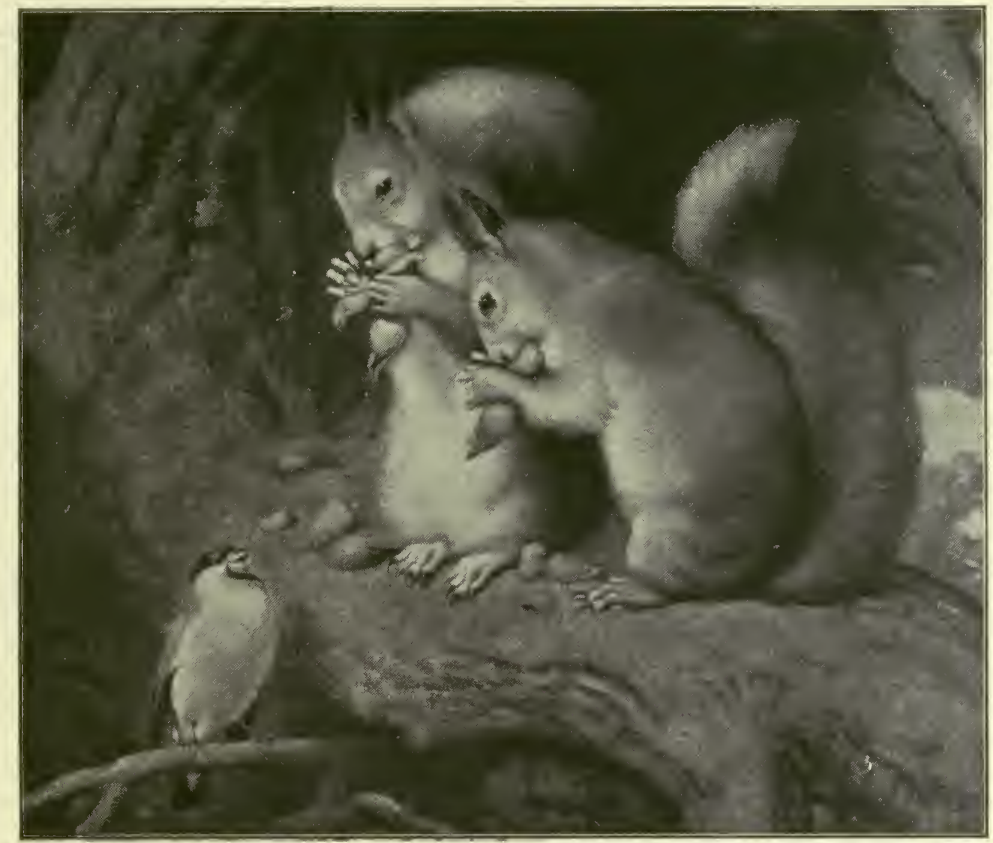

From a painting by Edwin Landseer

A PIPER AND PAIR OF NUTCRACKERS

\section{Lesson 28 \\ SQUIRRELS}

What are these squirrels doing?

Tell what you know about the squirrels' food.

Where do squirrels live and get food in winter?

How do they carry this food to their nests?

How do they keep warm during cold weather?

How do the coats of the squirrel and the bird differ? How do their coats look in this picture? 
I ITTLE squirrel, crack your nuts;

Chip your busy tune;

- Sound your merry rut-a-tuts -

Boys are coming soon!

Hide to-day and pile to-day,

Hoard a goodly store;

When the boys are gone away

You may find no more.

$-M . M . D$.

Illustrate this poem by a drawing.

\section{Lesson 29}

\section{EDWIN LANDSEER}

THE picture called "A Piper and Pair of Nut1 crackers" is a copy of a painting by Edwin Landseer, an English artist. This artist's home was in London, where he was born in 1802 .

When he was a little fellow, only four or five years of age, he delighted in drawing pictures of animals. On holidays he and his two older brothers used to leave the noisy, dusty city and _walk out into the green fields that lay beyond London. In one of these fields there was a great oak tree, and in its shade the three boys would sit, while 
Edwin drew pictures of the shaggy donkeys and thick-fleeced sheep that grazed around them.

Landseer's father encouraged and helped the boy in his drawing, and when Edwin grew older he was sent to an art school. There he worked so earnestly that, while he was still a very young man, he became well known as a painter of animals. He painted pictures of horses, deer, cattle, and sheep, of squirrels and of monkeys, but he was especially fond of painting dogs. He showed his fondness for dogs when very young, and on

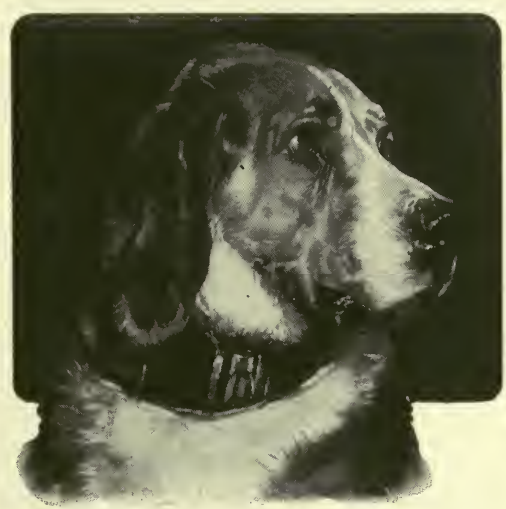

From a painting by Edwin Landseer $M Y D O G$ account of it was sometimes jokingly called "the little dog-boy."

Landseer loved animals. He studied their looks and actions and habits, and because of this love and knowledge of them his pictures are full of life.

Tell in your own words all you can of this artist. 


\section{Lesson 30 \\ THE MARKET}

Name as many as you can of the vegetables that are now in the market.

If you have seen any of them growing, tell where and describe the plant.

Tell what part of a plant each vegetable is.

How is each kind put up for sale? Who does all this work?

How is each kind measured?

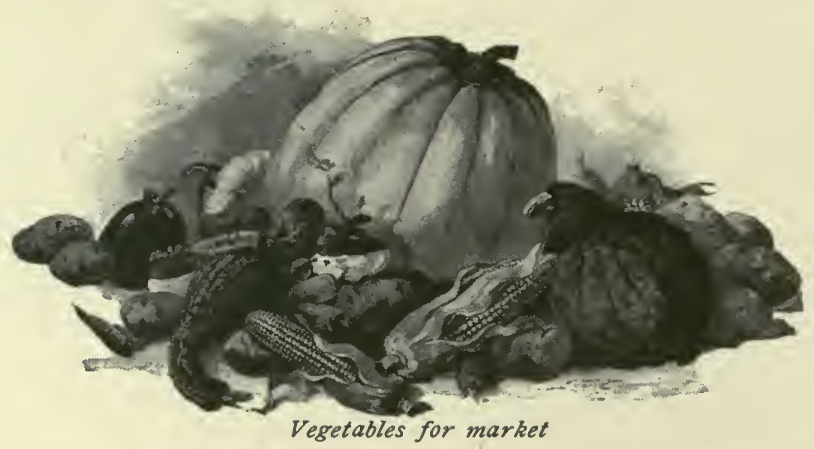

In writing you will sometimes find that you need to divide a word at the end of a line.

What word do you find divided in this lesson?

When a word is so divided a small mark (-) is placed after the part of the word that remains on the line. This mark is called a hyphen.

A word must always be divided between two syllables.

A word of one syllable must not be divided.

In the following lesson you may need to divide some word at the end of a line. 
A few of the words that you may need to use are given below, divided into syllables to show you how this may be done.

You will see that some words may be divided in more than one place.

$\begin{array}{llll}\text { ap-ples } & \text { cab-bage } & \text { cu-cum-bers } & \text { rad-ish-es } \\ \text { ap-ri-cots } & \text { car-rots } & \text { let-tuce } & \text { rhu-barb } \\ \text { as-par-a-gus } & \text { cau-li-flow-er } & \text { mel-ons } & \text { spin-ach } \\ \text { ba-na-nas } & \text { cel-e-ry } & \text { pars-ley } & \text { to-ma-toes } \\ \text { ber-ries } & \text { cher-ries } & \text { pump-kins } & \text { tur-nips }\end{array}$

\section{Lesson 3 I}

\section{PARTS OF PLANTS USED AS FOOD}

Write the title of this lesson, using capital letters correctly.

If you need to divide a word at the end of a line be sure to divide it between two syllables, and to use the hyphen.

Write a full sentence in answer to each of the directions in this lesson. Be careful to punctuate each series correctly.

Name two plants of which we eat the leaves.

Mention three plants of which we eat the stems.

Name as many as you can whose roots we use for food.

Of what plant do we eat the stalk and flower?

Of what plants do we eat the whole fruit?

Mention some fruits of which we eat only the pulp.

Of what plants do we eat only the seed?

Mention two plants of which we eat the whole seed.

What seeds do we crush or grind before using?

Some seeds are canned for winter use. Name three. 


\section{Lesson 32}

\section{HOW VEGETABLES ARE BROUGHT TO MARKET}

From whom does the market-man get his fruits and vegetables?

Describe some of the ways in which these things are brought to market.

Tell which fruits and vegetables in our markets have been brought each way, and why.

Mention some that grow near by.

Name some that come from far away, and tell where they grow. How are they kept fresh and sound on a long journey?

Can you name any of the workers who have helped to get these things to market for us?

\section{Lesson 33}

\section{STORING FRUITS FOR WINTER}

Mention some fruits that are dried for winter use, and describe the ways of drying fruit.

Tell what you know about making jelly.

What other things are made from fruit juice?

Name fruits that are canned or preserved. What part of the fruit is used in each case?

What do you know about the making of pickles and catsup?

Name any fruits that we can keep fresh for winter use and tell how they are stored. 


\section{THE APPLE HOLE}

D you remember the apple hole in the garden or back of the house, Ben Bolt? In the fall after the bins in the cellar had been well stocked we excavated a circular pit in the warm mellow earth, and covering the bottom with clean rye straw, emptied in basketful after basketful of hardy choice varieties, till there was a tent-shaped mound several feet high of variegated fruit. - Then, wrapping it about with a thick layer of long rye straw, and tucking it up snug and warm, the mound was covered with a thin coating of earth, a flat stone on the top holding down the straw. As winter set in another coating of earth was put upon it, with perhaps an overcoat of coarse dry stable manure, and the precious pile was left in silence and darkness till spring.

$* * * * *$

As the supply in the bins and barrels gets low and spring approaches, the buried treasures in the garden are remembered. With spade and axe we go out and penetrate through the snow and frozen earth till the inner dressing of straw is laid bare. It is not quite as clear and bright as when we placed it there last fall, but the fruit beneath, which the hand soon exposes, is just as bright, and far more luscious.

-From "Winter Sunshine," by John Burroughs. 


\section{Language Through Nature}

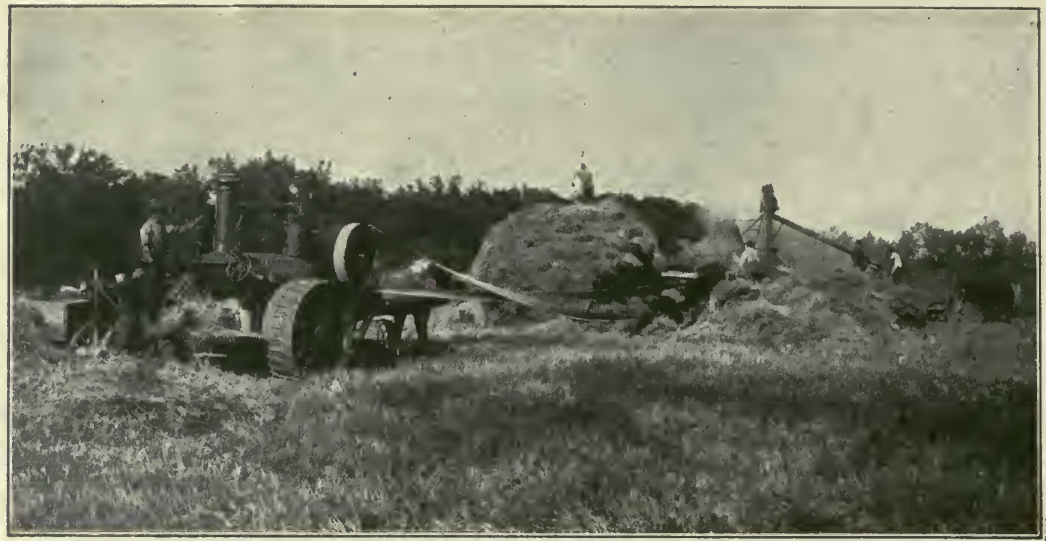

Threshing in the autumn

\section{Lesson 34}

\section{THE FARM IN AUTUMN}

Have you ever been on a farm in autumn?

What is put into the cellar?

What is put into barns?

What is put into the granary?

Tell about any other ways that you know of in which the farmer stores things for winter.

What work can the farmer do out of doors after he has gathered and stored his crops?

What changes are made at this season in the care given the farm animals? Why must all this work be done?

Write a letter to your teacher telling of some work that is being done in your home at this season.

Remember to begin each sentence with a capital letter and end it with the proper mark. Arrange your letter with care. 


\section{HARVEST SONG}

UMMER is gone, autumn is here,
This is the harvest for all the year.

Corn in the crib, oats in the bin, Wheat is all threshed, barley drawn in.

Carrots in cellars, beets by their side, Full is the hay-loft, what fun to hide! Apples are barreled, nuts laid to dry, Frost on the garden, winter is nigh.

Father in Heaven, thank thee for all, Winter and spring-time, summer and fall. All Thine own gifts to Thee we bring, Help us to praise Thee, our Heavenly King. - Lydia A. Coonley.

\section{SUGGESTED WORK}

I. Peel several apples. Cut each apple into halves and each half into thirds. Cut out the core that is left in each part.

Thread a darning-needle with a small white cord about a yard long. On this, string the pieces of apple. Remove the needle and tie the ends of the cord together. Hang the string of apples where the dry air can reach it freely.

Write a description of what you have done. Keep this paper carefully, and after about a week add a few sentences, telling what has happened to the apples.

2. Select one or two juicy apples or some ripe grapes. Press the juice out into a dish and note the smell and the taste.

Allow this juice to stand for a day or two; again note the smell and the taste. What change has taken place? Write a description of what you did and tell what happened. Tell of other instances in which you think a similar change occurs. 


\section{'Lesson 35 \\ A PICTURE STUDY}

What do you see in this picture?

What can you say of the man and the horse?

Where do you think they are going?

Describe the road. Why is it called "lonely"?

Why does the road seem narrower in the distance?

Tell what you notice about the trees in the foreground compared with those in the distance.

Where in the picture can you see water?

What can you say of the sky? Where do you see birds? What are they doing?

Of what time of day do you think this picture tells?

Of what season does it seem to be?

Mention all the things in the picture that tell about the season.

Give the name of the picture and of the artist.

What do you like about the picture?

\section{Lesson 36}

\section{A FAMOUS DUTCH PAINTER}

VEARLY a hundred years ago, in a little village 1 of Holland, there lived a bright, happy-faced little boy. Like the boys and girls of our own country, this boy was fond of reading fairy tales. Curled up in a great armchair many were the 


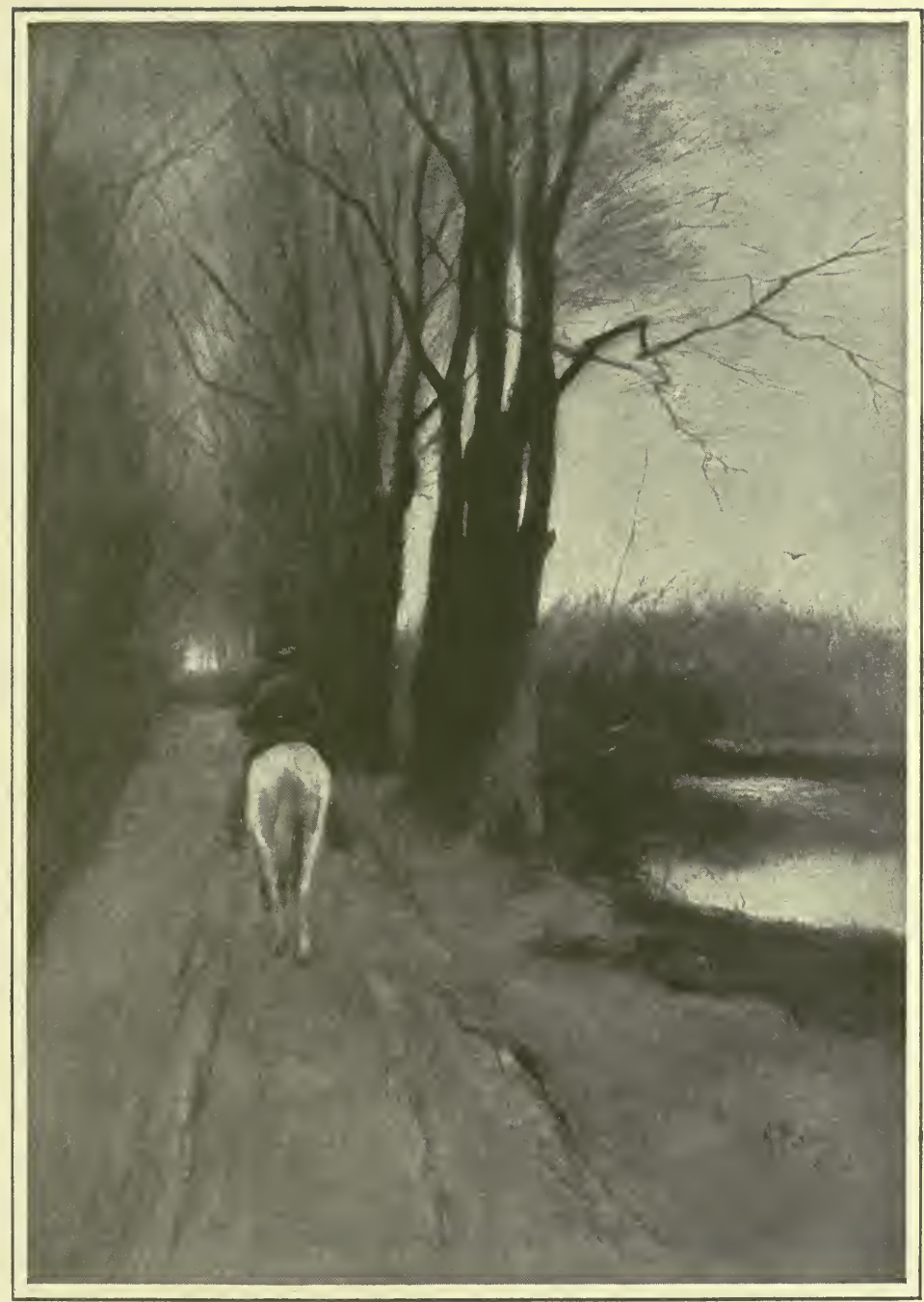

From a painting by Anton Mauve

THE LONELY ROAD 
delightful hours he spent sharing the adventures of the Tin Soldier, traveling with the Ugly Duckling, or living in the depths of the pleasant forest with the discontented Fir-Tree. And when he lifted his eyes from the pages of the book and looked out of the window down the quaint street of the little Dutch village, it seemed to him as if he were looking into fairyland. When he walked out into the quiet country, where the great windmills stood, and large-eyed cows and flocks of sheep grazed in the peaceful meadows by the canals, it seemed to the little dreamer as if fairyland lay all about him.

Seeing and loving the beautiful things around him made the boy long to make pictures that would express the beauty that he saw and loved. He began to draw when a small lad, and he "tells us that he spent his fifteenth birthday out in the meadows, making pictures of cows.

The boy's name was Anton Mauve. His family thought making pictures a great waste of time, but the boy was determined to be an artist. For years he had no teacher of drawing, but he learned to draw skillfully by going into the fields and woods and making pictures of trees, of sheep and cattle, and of men at work. 
For years he studied and painted by himself, with little or no encouragement. The great beauty of the country around his village home brought other painters there, and Anton made friends with the older artists, who helped and encouraged him in his work. Cheered by these friends, the young artist worked on. He won success, and to-day is known as one of the great painters of Holland. Like many other artists, Mauve delighted in painting cows and sheep, but he often chose other subjects, and the "Lonely Road" which you have been studying is one of his pictures.

Through all his busy life Mauve delighted in the beauty and gladness of Nature. He liked to walk out when the silvery moonlight fell softly over land and sea. He would stand still in the midst of the silence and beauty like one listening to exquisite music.

He worked with great rapidity, painting many pictures full of that sweet spirit of peace and happiness that filled his own life.

Tell what you can of the life and work of Anton Manve. 


\section{Lesson 37}

\section{SUMMARY OF WEATHER RECORDS}

Make summaries of your observations on the weather for the past month. Remember that names of months and days of the - week begin with capital letters. Remember that a period follows an abbreviation.

Tell what you like best about this month.

Make a picture of an October landscape.

\section{Lesson 38 \\ EVAPORATION OF WATER}

Put a little water into a tin cup and place it on the stove or over an alcohol lamp. As the water becomes hot what do you observe?

Let the cup remain over the fire and tell what happens to the water. What causes this?

Where has the water gone?

Tell of any place where you have seen something similar.

Sprinkle a little water on a slate or piece of glass and place it in the sunshine.

What happens? What do you think causes this?

Tell of any place out of doors where you have seen wet things become dry.

What heats the air out of doors?

Mention out-of-door places where you have seen water.

What becomes of some of this water when the sun shines upon it? Will it ever come back to earth? 


\section{Literature and Art}

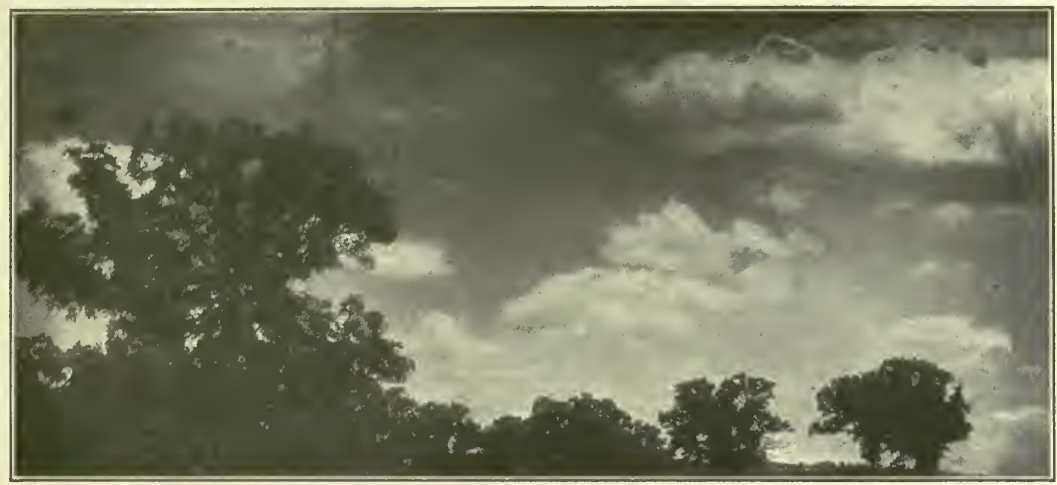

"I bring fresh showers for the thirsting flowers"

\section{Lesson 39 \\ THE CLOUD}

I BRING fresh showers for the thirsting flowers,

1 From the seas and the streams;

I bear light shade for the leaves when laid

In their noonday dreams.

From my wings are shaken the dews that waken

The sweet buds every one,

When rocked to rest on their mother's breast,

As she dances about the sun.

I wield the flail of the lashing hail,

And whiten the green plains under,

And then again 1 dissolve it in rain,

And laugh as I pass in thunder. 
Quote the words that tell where the cloud gets the showers. How do you think it gets them?

To whom does it bring them?

Tell when the cloud's shade is good for the leaves.

What are shaken from its wings at night?

How is the "lashing hail" like a flail?

How does it make the green plain look?

Tell into what the hail dissolves.

Do you like to hear the clouds laugh?

What do you like best in the cloud's work?

Copy this stanza. Use capital letters correctly in the title, to begin each line, and for the word $I$.

\section{Lesson 40 \\ CONDENSATION OF MOISTURE}

Hold a piece of cold glass, tin, or slate above a cup of hot water and tell what you observe.

What gathers on the glass and from what does it come?

How did it get to the glass and why did it stop there?

Where have you seen anything like this in your home?

What caused it to form?

From what did the moisture come?

Where and when have you seen dew?

Where was this moisture before it formed as dew?

How did it come to be there?

In what form do we sometimes see moisture in the air?

What causes it to fall to the earth?

In what form have you seen it falling?

Tell which form we see most during spring ; during sumsummer; and during autumn. 


\section{Lesson $4 \mathrm{I}$}

\section{THE RAINBOW FAIRIES}

TWO little clouds one summer's day,

1 Went flying through the sky,

They went so fast they bumped their heads, And both began to cry.

Old Father Sun looked out and said,

"O, never mind, my dears,

I'11 send my little fairy folk To dry your falling tears."

One fairy came in violet, And one wore indigo;

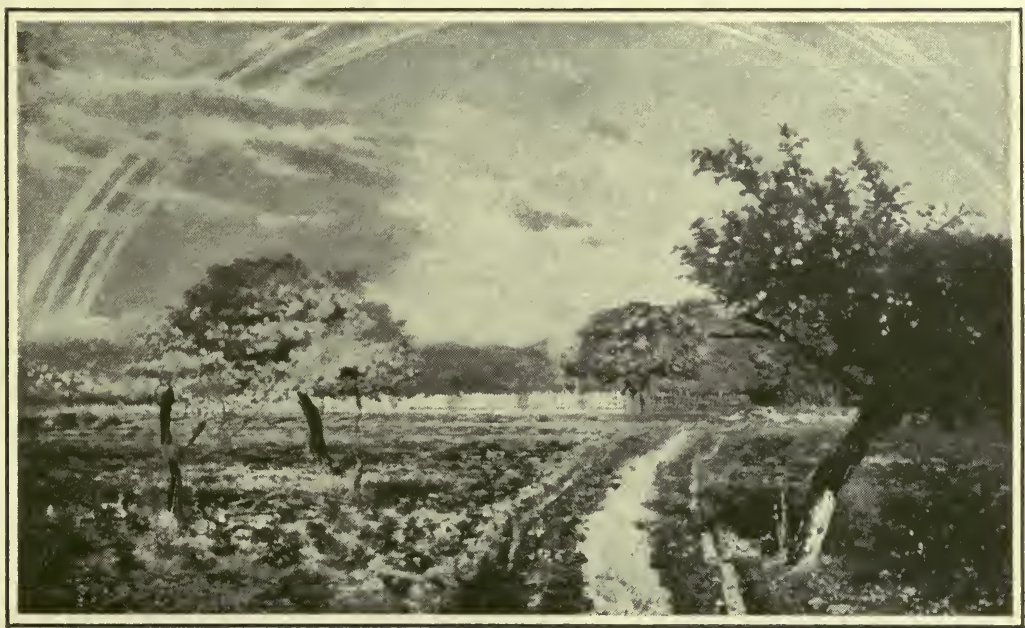

From a painting by Jean François Millet "They wiped the cloud tears all away" 
In blue, green, yellow, orange, red, They made a pretty row.

They wiped the cloud tears all away, And then, from out the sky Upon a line the sunbeam made, They hung their gowns to dry.

- Lizzie M. Hadley.

\section{When the word $O$ is used it is written as a capital letter.} Find this word in the poem.

What contraction do you find in this poem?

What helped the little clouds to fly so fast?

When clouds begin to cry what do we say is happening?

Quote the words that tell what Father Sun said to the little clouds. Who are the "fairy folk" sent by Father Sun to dry the clouds' tears?

Name the colors of the fairies' dresses. When these fairies hang out their dresses in the sky what do we say that we see?

When Hiawatha saw this he whispered:

"What is that, Nokomis?"

And the good Nokomis answered:

"'Tis the heaven of flowers you see there;

All the wild-flowers of the forest,

All the lilies of the prairie,

When on earth they fade and perish,

Blossom in that heaven above us."

-From "Hiawatha," by Henry W. Longfellow. 


\section{Literature and Art}

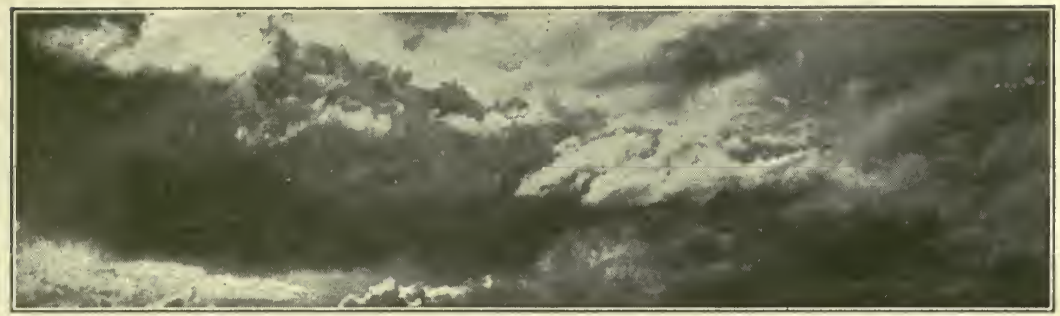

Moisture in the air

\section{Lesson 42 \\ USES OF STEAM}

DID you ever sit by the fire and watch a teakettle of boiling water?

Did you see the teakettle cover move up and down?

A boy once sat by the fire and watched a teakettle in which the water was boiling very fast. Steam was crowding from the spout as fast as it could, and every little while the teakettle cover would give a little hop and tiny puffs of steam would come out

"Steam was crowding from the spout" around its edges.

The boy wondered what made the cover move and watched to see if he could find out. At last he 
made up his mind that when the steam in the kettle could not get out fast enough through the spout it pushed the cover up so that some of it might get out that way. He thought that steam must be very strong to lift the cover, and wondered if it could lift other things. He tried to make it do so and at last he found a way. A machine was made in which steam was used to push and lift heavy things, and it was called a steam engine. At first this machine did not work very well, but after a long time a much better way to make it was found by a man named James Watt. He is often called the inventor of the steam engine.

It is many years since James Watt lived and worked, and since his time many new things have been found out about steam engines and the work they can be made to do. They are now used on land and on water, on farms and in cities. Where animals, wind, and water were once used to lift or push or pull, the steam engine is now usually found doing the work in a much quicker and better way.

Tell about some of the work you have seen steam engines doing.

Make pictures or cuttings of locomotive engines and steamboats. 


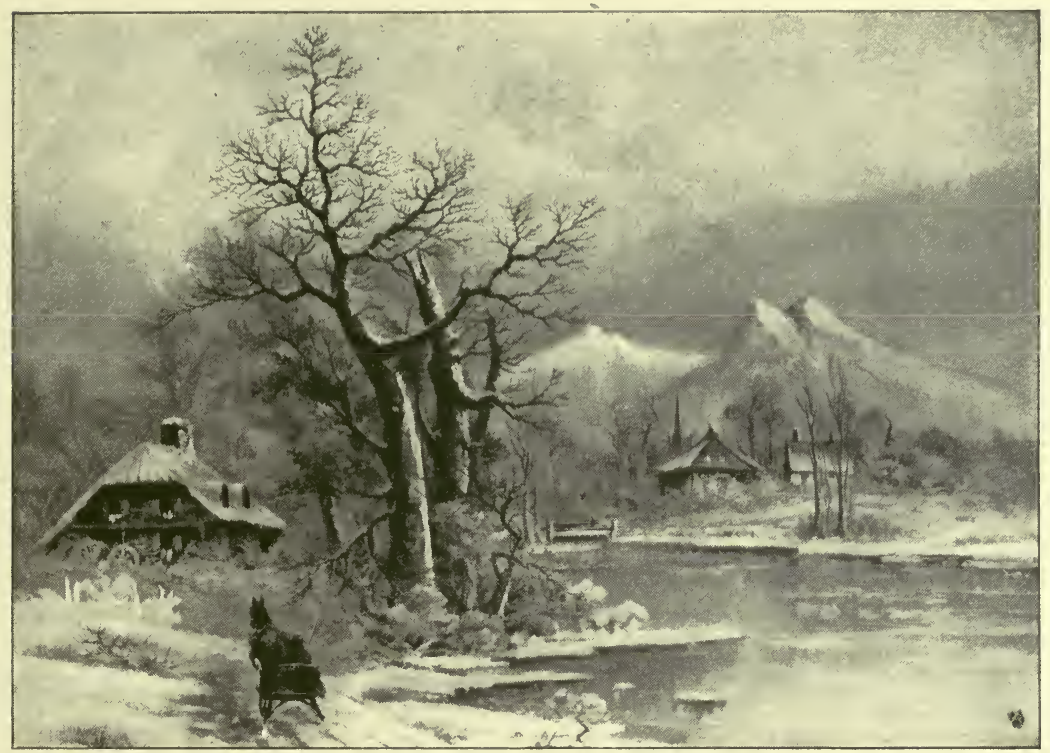

"All pictured in silver sheen"

\section{Lesson 43}

\section{THE FROST}

THE Frost looked forth one still, clear night,

1 And whispered, "Now I shall be out of sight, So through the valley and over the height In silence I'll take my way.

I will not go on like that blustering train, The wind and the snow, the hail and the rain, Who make so much bustle and noise in vain. But I'1l be as busy as they.' 
Then he flew to the mountain and powdered its crest,

He lit on the trees and their boughs he dressed

In diamond beads, and over the breast

Of the quivering lake he spread

A coat of mail that need not fear

The downward point of many a spear.

That he hung on its margin far and near,

Where a rock could rear its head.

He went to the window of those who slept, And over each pane like a fairy crept.

Wherever he breathed, wherever he stepped,

By the light of the moon were seen

Most beautiful things; there were flowers and trees;

There were bevies of birds, and swarms of bees, There were cities and temples, and towers and these

All pictured in silver sheen.

But he did one thing that was hardly fair.

He peeped in the cupboard, and finding there That all had forgotten for him to prepare,

"Now just to set them thinking - 
I'll bite this basket of fruit," said he, "This costly pitcher I'll break in three, And the glass of water they've left for me, Shall 'tchick to tell them I'm drinking."

-Hannah F. Gould.

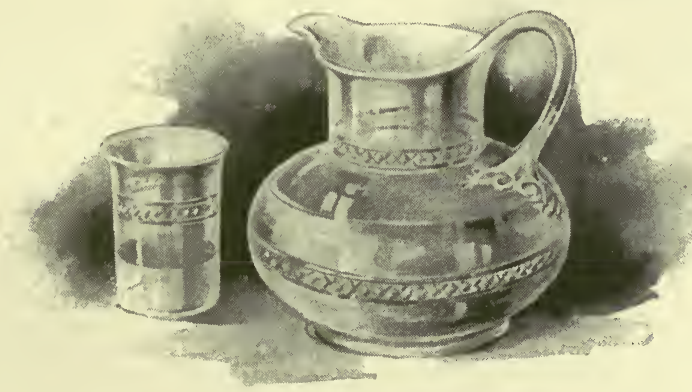

"This costly pitcher I'll break"

Tell in your own words the story of what the frost did.

\section{Lesson 44}

\section{HOW FROST IS FORMED}

Name places where you have seen frost.

Tell how frost looks and feels.

What happens to the frost when the sun shines upon it?

Name some place where you have seen this happen.

If you scrape a little frost from the window-pane into your hand, what happens?

If you bring twigs or grasses that are covered with frost into a warm room, how are they changed? Into what does the frost change in each case? 


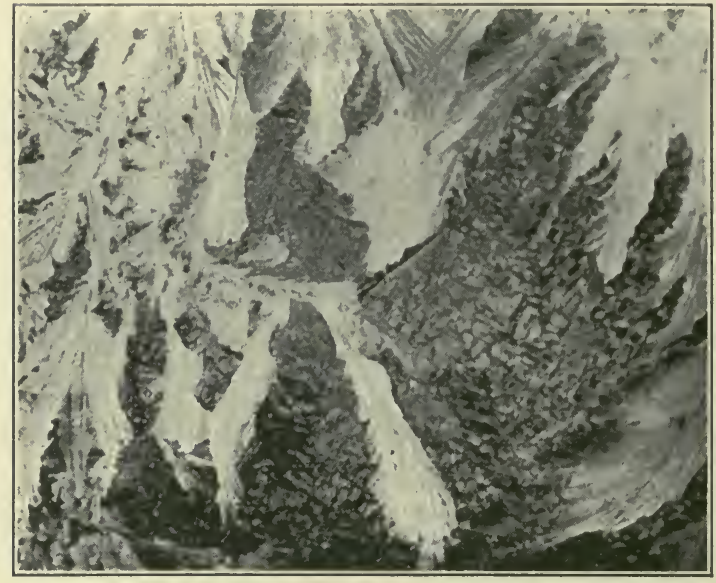

A frosty window

Where was this before it became frost?

What caused it to change into frost?

What change in temperature have you observed since September. (Look at weather records if necessary.)

What does the record tell about dew or frost?

As the amount of heat in the air grows less, what seems true about dew or frost? SUGGESTED WORK

If you would like to see frost form, follow these directions :

Put a mixture of one-third salt and two-thirds snow or crushed ice into a tin cup. Hold the cup near steaming water so that the moist air may strike it.

Watch closely and see what happens.

\section{Lesson 45 \\ PREPARING FOR WINTER}

What do your weather records tell about the temperature and the length of day at this season?

Describe any changes that are being made about your house now. Who puts on the storm windows and doors?

Tell about any changes that are being made in the heating and lighting.

What merchants become very busy at this season?

What changes do people make in their clothing? 
What changes do you notice in the goods shown in the windows of dry goods and clothing stores?

What changes are made in the street cars?

\section{SUGGES'TED WORK}

Take a piece of woolen cloth and ravel it out. Untwist some of the threads that you get and pull them apart so that you can see the fine wool fibers.

Ravel some more of the cloth and watch carefully to see if you can find how the threads are put together.

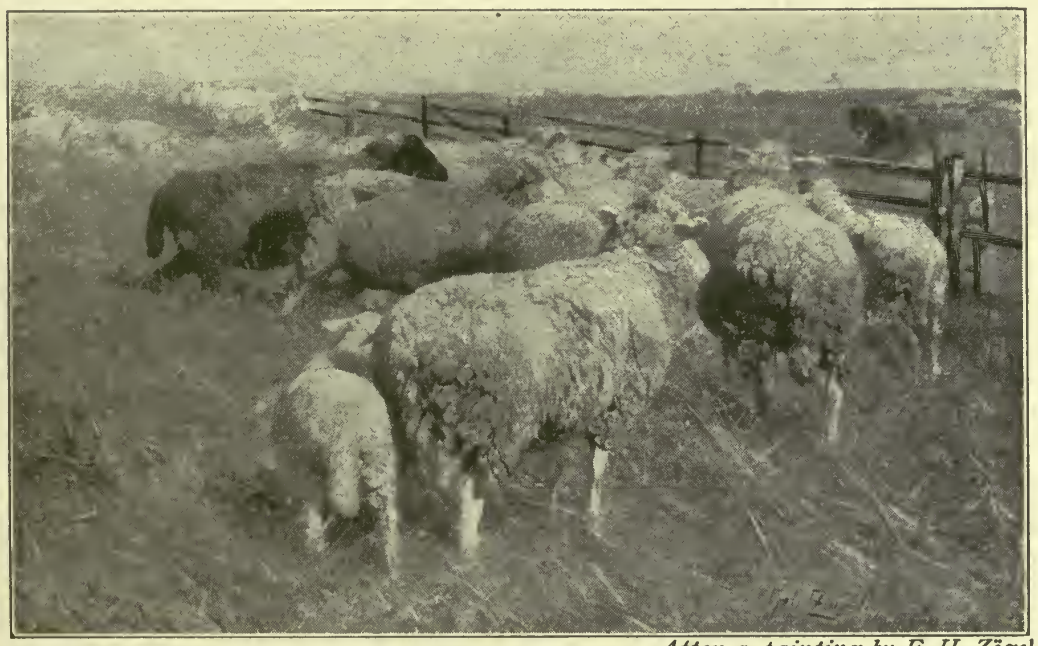

WAITING

After a painting by $F . H$. Zögel

\section{Lesson 46}

\section{WOOL}

Of what kind of cloth is most of the clothing made that we put on when cold weather comes?

Of whose warm coat was this once a part?

How was it gotten from his back? 


\section{Language Through Nature}

'The wool fibers were straightened out by a process called combing or carding. Then it was spun into threads; and these in turn were twisted to make yarn.

If you have seen anyone spin, tell about it.

What is the color of natural wool?

How do we get so many colors of yarn and cloth?

Tell what you know about weaving. If you have seen a loom or a frame for weaving, describe it.

Bring pieces of woolen cloth of different colors and patterns to school. Make a picture showing the various ways of spinning or weaving.

\section{SUGGESTED WORK}

If possible, get part of a sheep's fleece. Take a little of the wool and pull it into a fine thread. Roll or twist it into yarn with the fingers.

Put a handful of logwood chips, or pieces of butternut bark, or a little indigo into a quart of water, let it boil, then strain. Add a little copperas or alum to fix the color. Put the wool or yarn into this dye and let it boil until colored as dark as you like. Rinse and dry the yarn.

Write a description of what you have done and tell the color of the yarn after it is dyed. Keep samples of the colored and uncolored yarn with your description.

Trace all the changes in the wool from the time it was part of the sheep's covering until it was ready for you to wear.

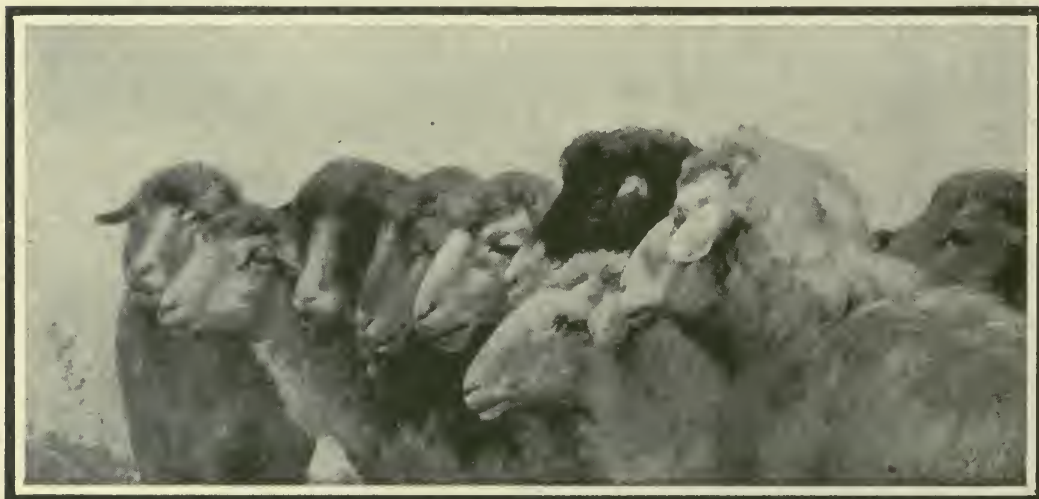




\section{Lesson 47}

THE COAT THAT JACK WEARS

THIS is the coat that Jack wears.

This is the cloth so warm and blue,

That made the coat that Jack wears.
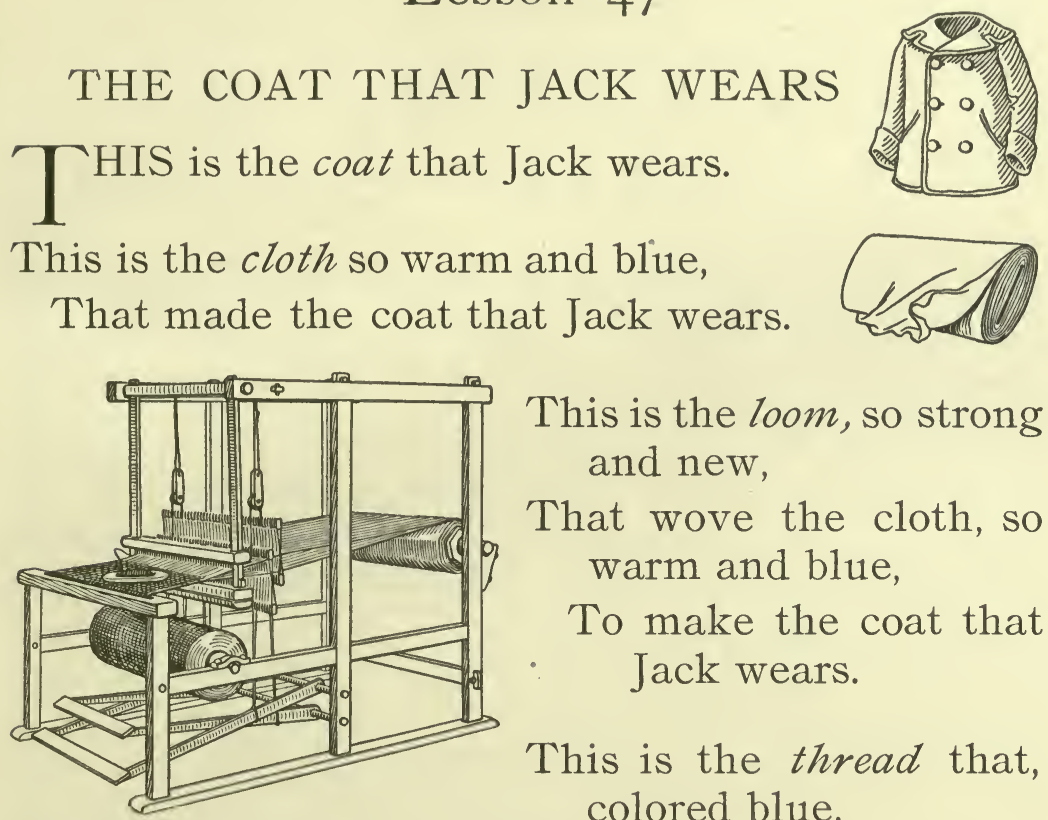

This is the loom, so strong and new,

That wove the cloth, so warm and blue,

To make the coat that Jack wears.

This is the thread that, colored blue,

Was used in the loom, so strong and new,

To weave the cloth, so warm and blue,

To make the coat that Jack wears.
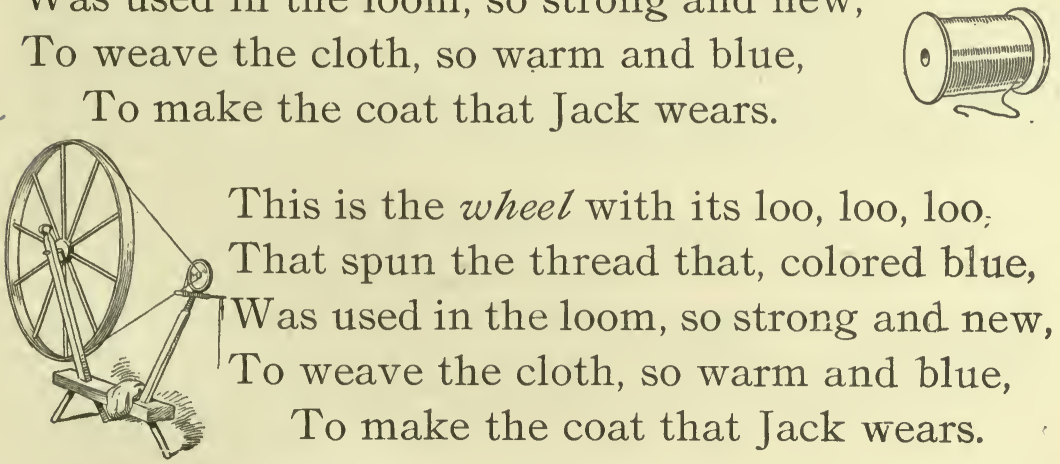

This is the wheel with its 1oo, loo, loo;

That spun the thread that, colored blue,

Was used in the loom, so strong and new,

To weave the cloth, so warm and blue, To make the coat that Jack wears. 
This is the wool, carded through and through, That was spun on the wheel, with its 10o, 1oo, 1oo, To make the thread that, colored blue, Was used in the loom, so strong and new,

To weave the cloth, so warm and blue, To make the coat that Jack wears.

This is the sheep on which there grew The wool that, carded through and through,

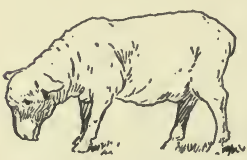

Was spun on the wheel with its 100 , 1oo, 1oo, Was used in the loom, so-strong and new, To weave the cloth, so warm and blue, To make the coat that Jack wears.

This is the man, and his scissors, too, That sheared the sheep on which there grew The wool that, carded through and through, Was spun on the wheel with its 1oo, 10o, 1oo, To make the thread that, colored blue, Was used in the loom, so strong and new,
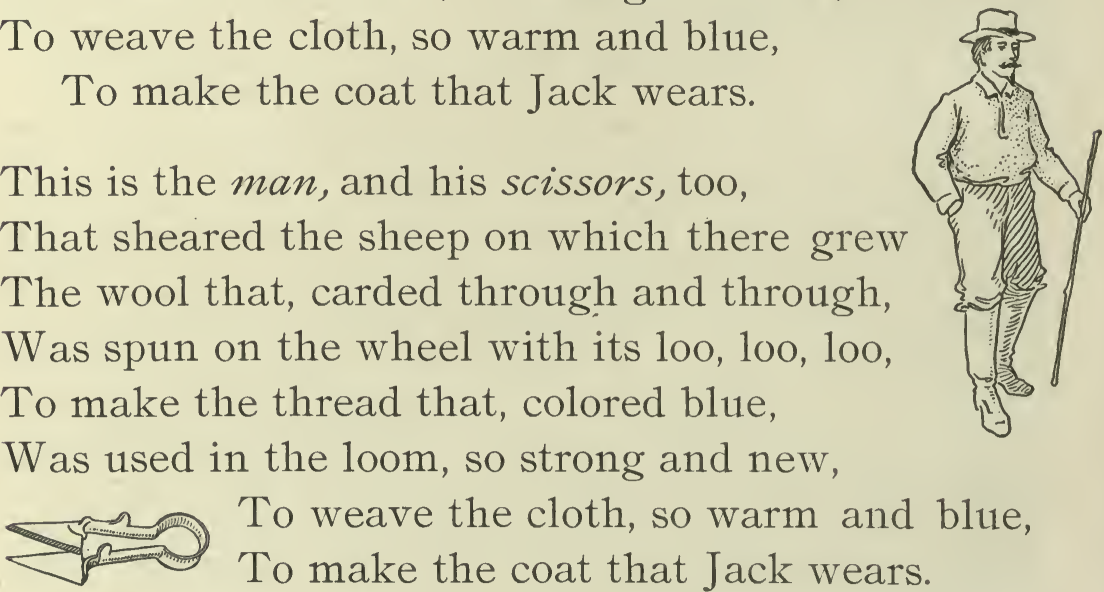
To weave the cloth, so warm and blue, To make the coat that Jack wears. 


\section{Lesson 48 W.EAVING}

Indians weave on the kind of loom you see in this picture. Describe the loom and tell where it is placed.

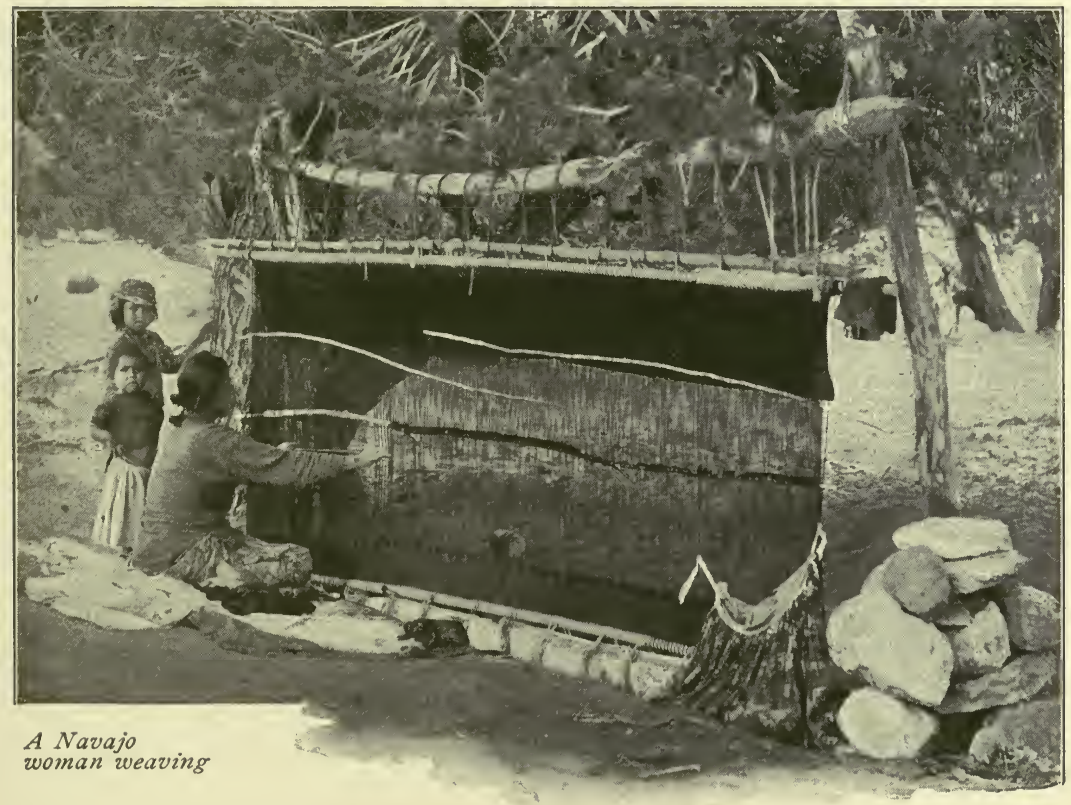

By whom do you think the weaving is done?

Where do you think the Indians get the wool?

How do you think they make the yarn?

If you have seen any articles woven by the Indians, tell what colors were used most.

Tell how you think they dye the yarn. 
How are spinning and weaving done now?

Mention other things besides cloth that are woven from yarn. Where are they woven? How were they brought here?

Tell of other ways in which things are made from yarn.

Can you knit or crochet?

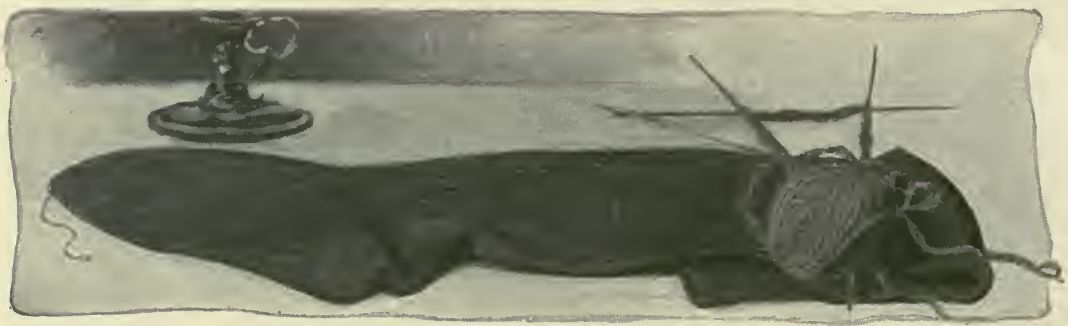

Mother's knitting

SUGGESTED WORK

Take pieces of woolen cloti - plain, striped, checked, and plaid - and examine them to find how they were woven to make the colors appear in patterns. Ravel the cloth, if necessary. The threads that run lengthwise are called the warp. The threads that are carried by the shuttle back and forth through the warp are called the filling, or woof.

Some of the best wool goods and the finest patterns of plaids are made in Scotland. There each family or clan keeps its own plaid for generations.

With colored crayons make a design in stripe or check for weaving.

Make a simple loom by driving tacks or small nails opposite each other into the ends of a smooth board eight inches wide and twelve inches long. Fasten yarn back and forth from opposite tacks for the warp.

Wind yarn on a piece of cardboard to be used as a shuttle, and weave by passing over and under threads, according to your design. Make a table mat or holder cover from what you weave.

Write what you have done and tell for what you use your weaving.

Many artists are busy making beautiful patterns or designs to be woven into cloths, carpets, rugs, or curtains. They use the shapes of leaves, flowers, fruits, and many other things in making these designs.

Choose some form that you like, and make with it a design for weaving. Color this design as you would like to see it, or tell the colors in which you would like to have it woven. 


\section{Lesson 49 \\ WOVEN PICTURES}

VERY many years ago, in some of the countries across the ocean, the men and women were called knights and ladies. When the knights did brave things in hunting or in war, the ladies used to weave by hand or embroider, in bright colors, pictures telling about these deeds. These fabrics were hung on the castle walls, and are called tapestry. Beautiful pieces of tapestry have been brought to this country and you may some day see some of them.

Write the story of any deed that you think worth weaving into a tapestry picture.

Remember to use capital letters correctly in writing titles, the first word in every sentence, and the name of a person. If you write the name of a place, remember that it should begin with a capital letter.

If possible, have the class visit some large store to see carpets, rugs, and draperies.

Howe'er it be, it seems to me,

'Tis only noble to be good.

Kind hearts are more than coronets, And simple faith than Norman blood. 


\section{Lesson 50}

\section{ARACHNE}

T $\mathrm{N}$ a far country called Greece there once lived a 1 beautiful maiden named Arachne. She could spin and weave so wonderfully that people came from far and near to see her work. So fine was the yarn that she spun and so beautiful the colors and designs of her weaving that people said, "It must be that Athena, queen of the air, has taught this maiden."

But Arachne had grown proud of her skill and wished to take all the praise for herself, so she answered, "No one taught me; I taught myself, and no one else in the wide world can spin or weave so well as I."

When Athena heard this boast she came

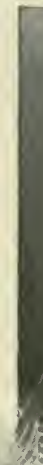


to Arachne and said, "I am Athena, Queen of the Air. No spinning or weaving can equal my own. You must know that I taught you to do these things." But Arachne proudly answered, "No one taught me, and no one else's work is so wonderful as mine."

Athena replied, "The truth must be made known. In three days I will come again and we will each weave for all the world to see. If your work is judged best I will never spin or weave again, and if mine is judged best you shall never again use distaff, spindle, or loom."

The day came, and all the world waited to see the contest. Arachne's loom was out under the green trees, and all watched with delight, as the fine silken web with its beautiful designs and brilliant colors came from her loom. It seemed as though nothing more beautiful could be made.

But soon Athena began to weave. Her loom was in the sky, and as she wove it seemed like the unrolling of beautiful pictures. The people forgot all else, even the web of Arachne, and watched only this wonderful weaver. Arachne watched, too, and as the thought of what she had felt and done swept over her, her pride was shamed. She realized also that she could never again use her loom, and her tears fell fast. 
When Athena saw Arachne's grief she felt sorry for her and said, "I may not change what has been said, but I will change you so that you may spin and weave without spindle or loom." Then she touched Arachne and the people no longer saw a beautiful maiden, but there among the leaves was a happy spider spinning a most
Wonderful silken web.
What if all spiders are descendants of

As you begin to read the story of Arachne, notice that the first section or group of sentences tells about Arachne and her work.

Read on and you will see that each group of sentences seems to tell a particular part of the story.

These sections or groups of sentences relating to the same part of a story or composition are called paragraphs.

In writing or printing, the division into such parts is shown by beginning the first sentence of the paragraph at more than the usual distance from the margin.

Study this story to find the part told by each paragraph.

Write the story in your own words, being careful to arrange it in paragraphs.

Remember to place the first word of each paragraph at the proper distance from the margin.

If you use quotations punctuate correctly. 


\section{Lesson 5 I}

\section{HIAWATHA'S HUNTING}

THEN he said to Hiawatha:

1 " "Go, my son, into the forest,

Where the red deer herd together,

Kill for us a famous roebuck,

Kill for us a deer with antlers!"

Forth into the forest straightway

All alone walked Hiawatha

Proudly, with his bow and arrows;

* * * * *

From the red deer's hide Nokomis

Made a cloak for Hiawatha,

- From the red deer's flesh Nokomis

Made a banquet to his honor.

All the village came and feasted,

All the guests praised Hiawatha,

$$
\begin{array}{cc}
* \quad * \quad * \quad * & * \\
& - \text { Henry W. Longfellow. }
\end{array}
$$

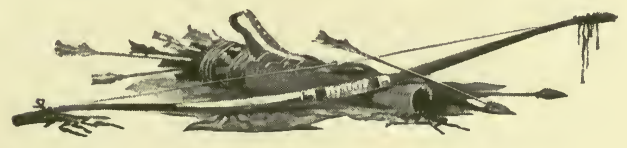


Write the story of Hiawatha's hunting in your own words.

In the first paragraph state where he was sent, what he was told to do, and what weapons he took.

In the second, describe how he felt to be sent on such an errand, and how he succeeded in his hunting.

In the third, tell what Nokomis did in Hiawatha's honor, who came to the banquet, and what the guests said of Hiawatha.

In the fourth, tell what use was made of the deer's hide and flesh.

\section{Lesson 52 \\ USES OF COVERINGS OF ANIMALS}

When we say "Hiawatha's cloak" we mean that the cloak belonged to Hiawatha, or was owned by him.

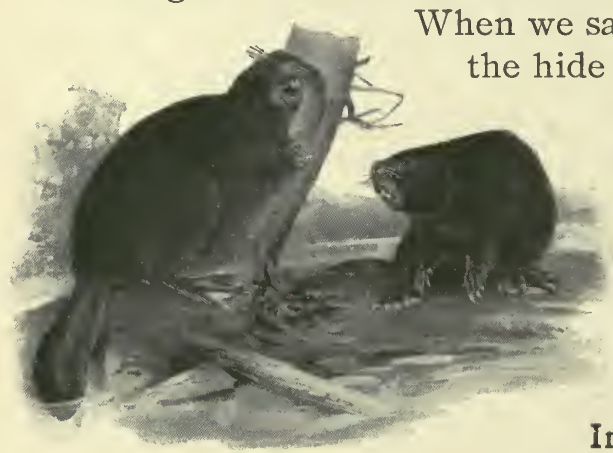

Beavers at work the apostrophe only is added.

Tell for what the following coverings of animals are uscd, writing full sentences, and using the possessive form to express ownership.
alligator's skin
calf's skin
goat's skin
bear's skin
cow's hide
seal's fur
bird's feathers
deer's skin
sheep's wool 


\section{Lesson 53}

\section{THE LANDING OF THE PILGRIMS}

THE breaking waves dash'd high

1 On a stern and rock-bound coast,

And the woods against a stormy sky

Their giant branches toss'd ;

And the heavy night hung dark

The hills and waters o'er,

When a band of exiles moor'd their bark

On the wild New England shore.

Not as the conqueror comes,

They, the true-hearted, came;

Not with the roll of stirring drums,

And the trumpet that sings of fame;

Not as the flying come,

In silence and in fear; -

They shook the depths of the desert gloom

With their hymns of lofty cheer.

- Mrs. Felicia Hemans.

Learn this poem. Tell the story in the poem, using your owen words.

Draw a picture of the "landing" as it is suggested in the second stanza. 


\section{Language Through Nature}

\section{Lesson 54}

\section{A PICTURE STUDY}

What are the people in this picture called?

Tell where you think they are going, and why they keep so near together.

Why do the men carry guns?

One man is not carrying a gun. Who do you suppose he can be?

What do you see in the distance?

What do the stumps here and there show you?

What in the picture tells you of the season?

Describe the dress of these people.

What do you think the artist wished to tell about these people?

What do you like in this picture?

If you write about this picture arrange your sentences in paragraphs.

\section{Lesson 55 \\ GEORGE H. BOUGHTON}

THE artist, George H. Boughton, was born in 1 England in 1832 , but he was brought to this country by his parents when he was only three years old, and his work is more American than English. 


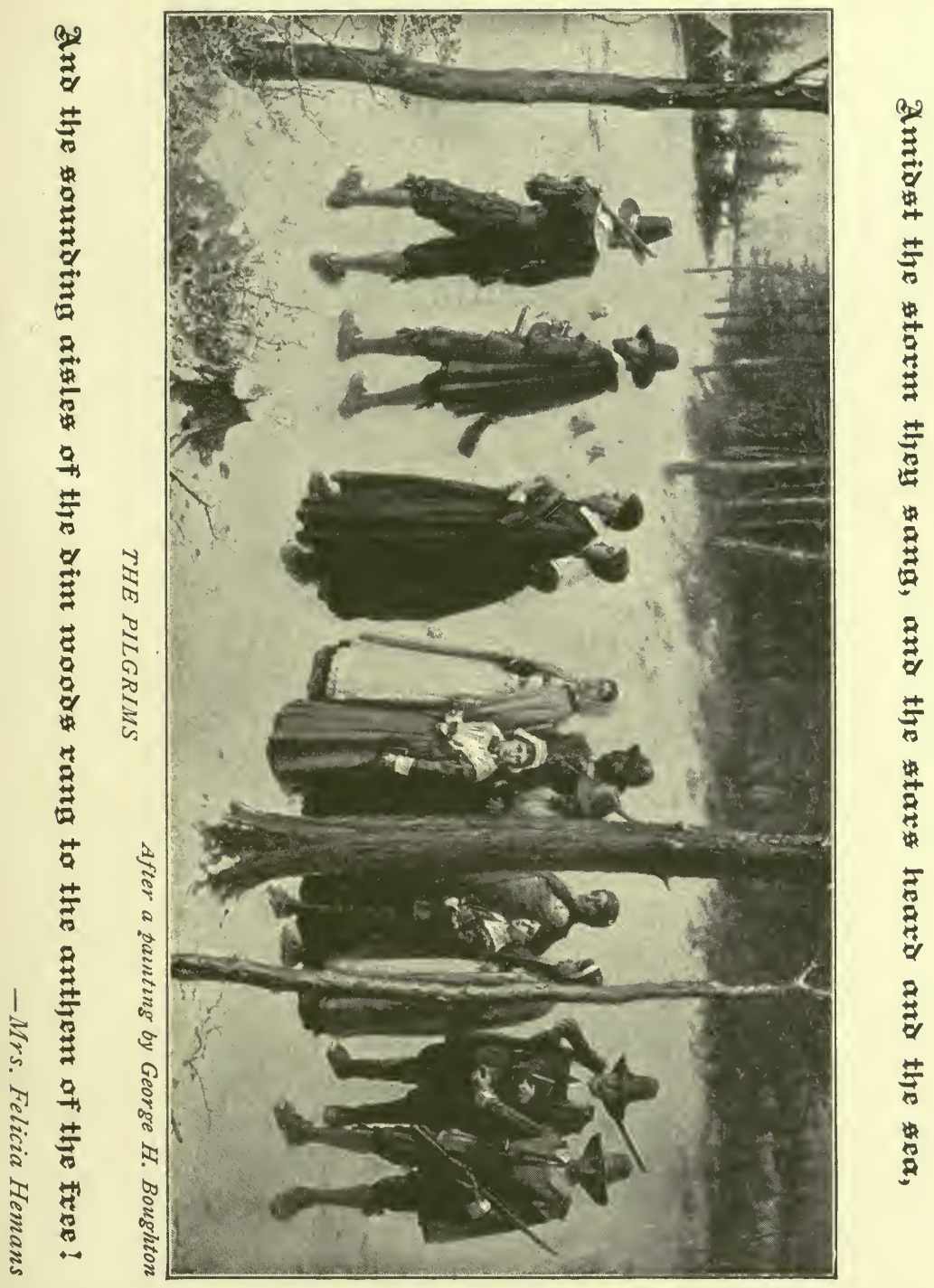


When Boughton was sixteen years of age he worked for his brother, who was a prosperous hat manufacturer. While in the shop the boy made many friends because of his even temper and cheerful disposition. During this time, although he had never been taught to draw, he made many little sketches that were much admired by his friends.

Boughton did not remain long in the shop. He left it to study art. He was his own teacher and his studio was the great outdoor world. He worked and studied in the silent, shadowy woods, or by the rocky shore of the ocean, and was so successful that in a few years he earned enough money by painting to enable him to go to London and study with some of the great masters. Later he went to Paris, where he studied for several years.

This artist has painted many pictures, each of which tells a story in a quiet, simple manner. Years ago he became interested in the Pilgrims, and a number of his best pictures show the life of those patient, heroic men and women who did what they thought right in spite of all difficulties and dangers.

Tell in your own words the story of this artist. 


\section{Lesson 56 \\ A LETTER}

Write a letter to your mother describing the Pilgrims, their houses, their food, and their friends.

Tell about the Thanksgiving feast which the Pilgrims gave and who were their guests.

Remember in writing to begin names of persons and places with capital letters. Use the correct form in words showing possession.

Arrange your sentences in paragraphs as you do in other written work. Be careful about the punctuation and the arrangement.

Enclose your letter in an envelope and address it correctly.

\section{Lesson 57 THANKSGIVING DAY}

You have been studying about the Pilgrims' Thanksgiving Day. Tell about our Thanksgiving Day.

Who sets the date of it? In what month and on what day of the week is it? Why is it kept at this season?

What do you do on Thanksgiving Day?

If you enjoy this holiday, tell why.

\section{Lesson 58}

\section{SUMMARY OF WEATHER RECORDS}

Make summaries of your observations on the weather for November.

Show, by a picture, the appearance of the landscape at this time. Tell of pleasant things to do during long evenings. 


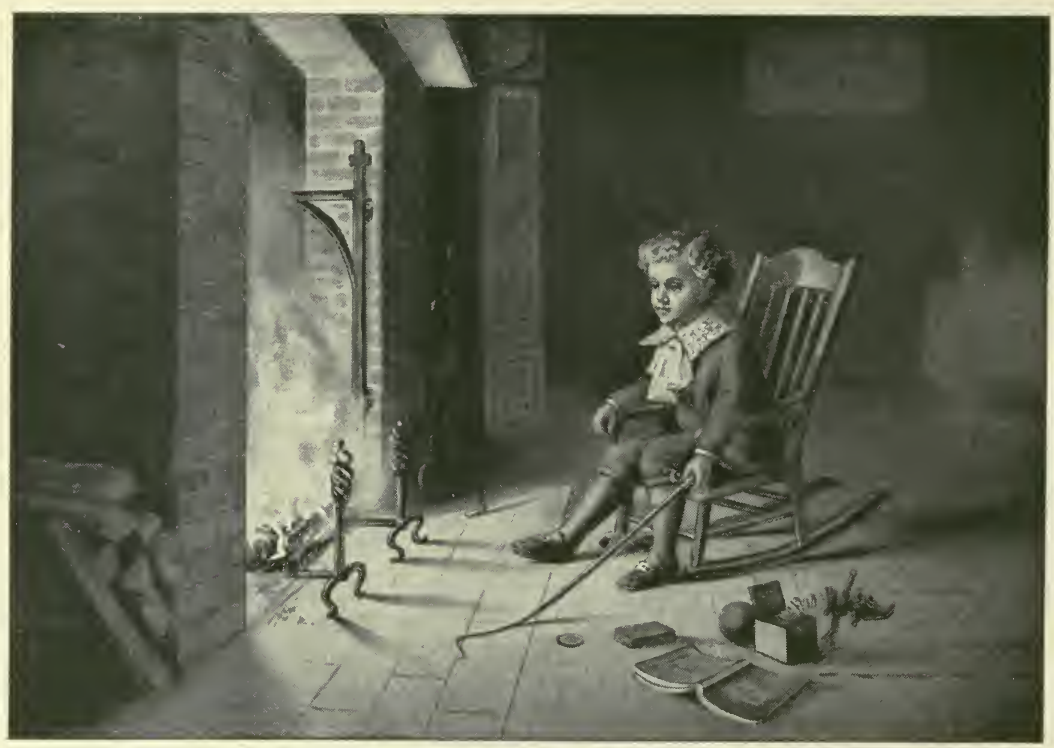

"As he rocked himself in his little arm-chair"

\section{Lesson 59}

THE STORY OF THE WOOD

What said the Wood in the fire To the little boy that night The little boy of the golden hair, As he rocked himself in his little arm-chairWhen the blaze was burning bright?

The Wood said: "See What they've done to me!

I stood in the forest, a beautiful tree, 
And waved my branches from east to west, And many a sweet bird built its nest

In my leaves of green

That loved to lean

In springtime over the daisies' breast!

"From the blossoming dells

Where the violet dwells

The cattle came with their clanking bells

And rested under my shadows sweet;

And the winds that went over the clover and wheat

Told me all that they knew

Of-the flowers that grew

In the beautiful meadows that dreamed at my feet!

* $*$ * * * * *

"And the lightning

Came brightening

From far skies, and frightening

The wandering birds that were tossed by the breeze And tilted like ships on black, billowy seas!

But they flew to my breast

And I rocked them to rest,

While the trembling vines clustered and clung to my knees!

"But how soon," said the Wood,

"Fades the memory of good! 


\section{0

Though with sheltering love and sweet kindness I stood,

The forester came with his ax gleaming bright, And I fell like a giant, all shorn of his might!

Yet still there must be,

Some sweet mission for me:

For have I not warmed you and cheered you tonight?"

So said the.Wood in the fire

To the little boy that night-

The little boy of the golden hair,

As he rocked himself in his little arm-chair-

When the blaze was burning bright.

- Frank L. Stanton.

Write in your own words the story of this poem.

In your first paragraph tell about the little boy, in the second describe the tree's home and its visitors, and in the third explain what happened to the tree and what new work it found to do.

Use all contractions and quotations correctly.

Make pictures illustrating the parts of the poem you like best.

\section{Lesson 60 \\ MODES OF HEATING}

Tell how your home is heated during the cold season.

How is your schoolhouse heated?

Mention all the ways you can in which houses are heated.

What kinds of fuel are used to produce the heat? 


\section{Lesson 6 I}

\section{A WOOD FIRE}

Where have you seen a wood fire?

As you sat by the fire what did you see and hear?

After the wood had burned away, what was left?

What kind of wood is usually used for fuel?

Tell where it is obtained and how it is prepared for use.

Of what do you suppose the Pilgrims made their fires, and why did they use it? Of what were the Indians' fires made, and how did they start a fire?

\section{Lesson 62}

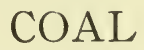

Name the different kinds of coal.

Tell all you can about each kind.

If you burn coal at your home, tell which kind you use.

Where do you get it, and how is it measured?

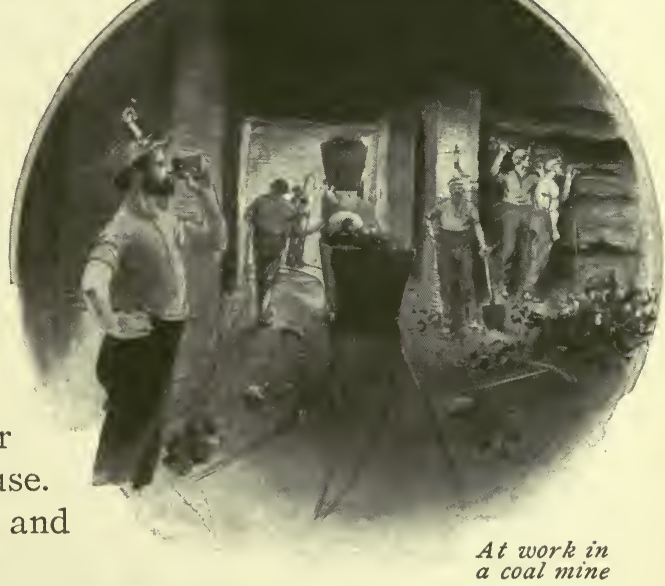

How is it brought to your home, where does the dealer get it, and how is it brought to his yards?

Tell what you can about coal mines.

Sing a song of seasons, something bright in all, Flowers in the summer, fires in the fall. 


\section{Lesson 63 \\ OTHER USES OF COAL}

What use does the blacksmith make of coal?

Of what use is it to the locomotive engineer?

For what is it used on steamboats?

Of what use is it in factories?

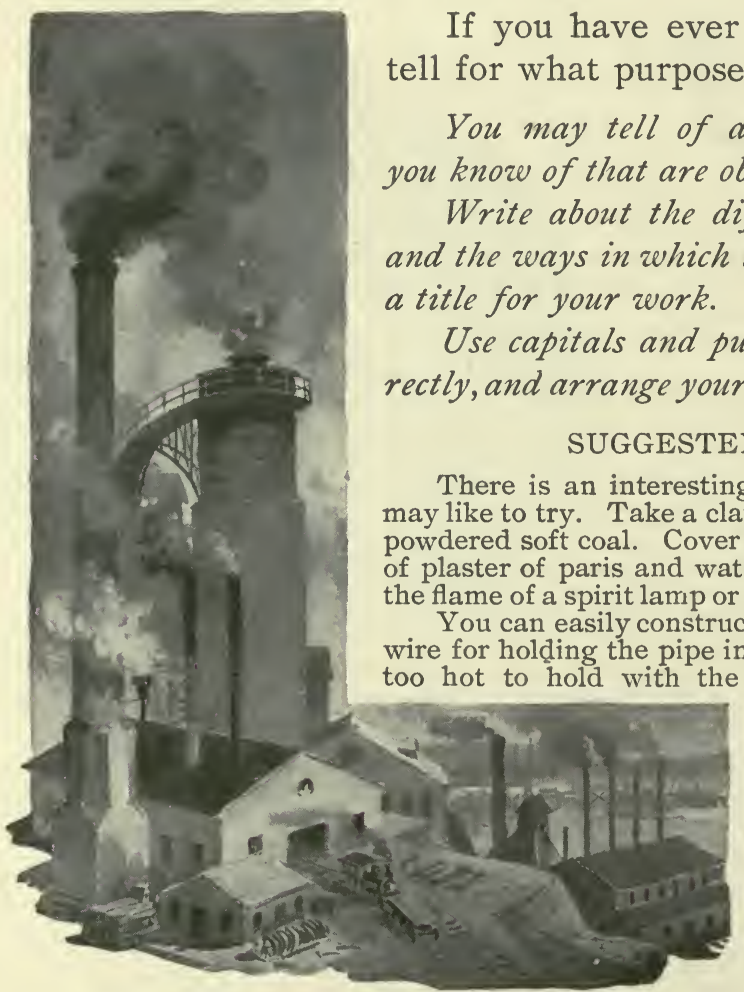

Where coal is uscd 


\section{Lesson 64 \\ LIGHT}

Of what use is sunlight to the world?

Tell at what time of the year the day is longest.

When do the days become short and the nights long?

Which is the longer now?

Why do we need light in our homes at night?

How is your home lighted?

How are churches and halls lighted?

Why is artificial light needed out of doors at night?

How are our streets lighted?

How are street cars and trains lighted?

Tell what you can about electric lights.

Alantern Make pictures of street lamps you have scen.

\section{Lesson 65 \\ LIGHTHOUSES}

If you have ever seen a lighthouse, tell where.

Where are lighthouses usually built?

What kind of buildings are they?

Tell where the light is placed.

For whose benefit is it used? Why?

In what other ways might a warning be given to sailors?

Tell which you think is the better way, and why.

Make a picture or a cutting of a lighthouse.

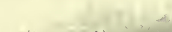




\section{Io4 Language Through Nature}

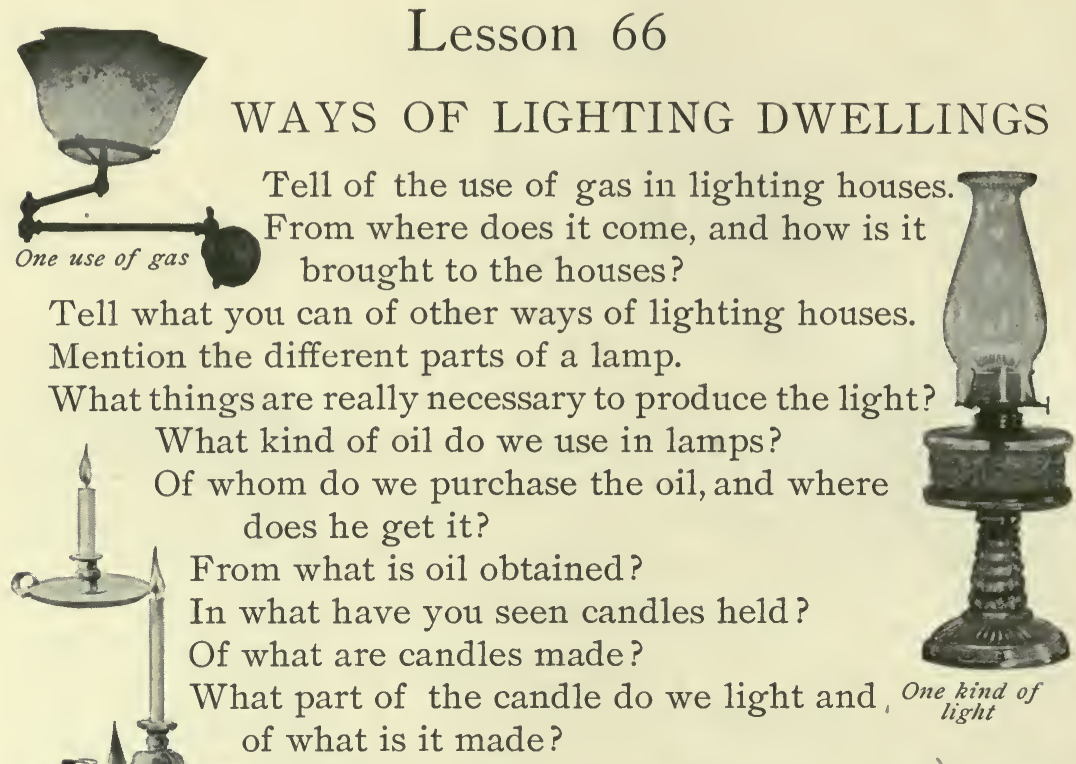

Before candles were invented how do you "Of what are think men used to light their dark dwellings?

How far that little candle throws his beams, So shines a good deed in a naughty world. - Shakspere.

Write a paragraph about each of the different kinds of light. Tell which one you think best and why.

SUGGESTED WORK

Light a wax candle. As the flame heats the wax, what happens? What do you see just around the wick? What prevents this from flowing away? What do you think becomes of it?

Blow out the light. What do you see now around and above the wick? Hold a lighted match in what you see, but do not touch the wick. Into what was the cold solid wax changed? Into what do you think the melted wax was changed? What do you think has caused these changes?

Write about this experiment, telling all you have done and what you saw. 


\section{Lesson 67}

\section{WINTER SONG}

\section{UURRAH for the jolly old winter,}

1 The king of the seasons is he,

Though his breath is cold and icy,

His heart is full of glee.

He piles up the beautiful snowflakes

On the apple trees bare and brown,

And laughs when the north-wind shakes them,

Like a shower of blossoms down.

Hurrah for the jolly old winter,

He shouts at the door by night,

"Come out where the ice is gleaming

Like steel in the cold moonlight."

Like swallows over the water,

The skaters merrily go,

There's health in the blustering breezes,

And joy in the beautiful snow.

- Emily Huntington Miller.

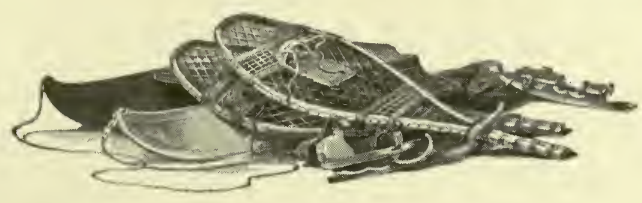


Copy this poem and memorize it.

Remember that the first word of every line of poetry begins with a capital letter.

Notice the quotation in the last stanza and be careful to inclose it in quotation marks. When writing a contraction remember to use the apostrophe. Place all other punctuation marks carefully. Make pictures or cuttings to illustrate winter sports.

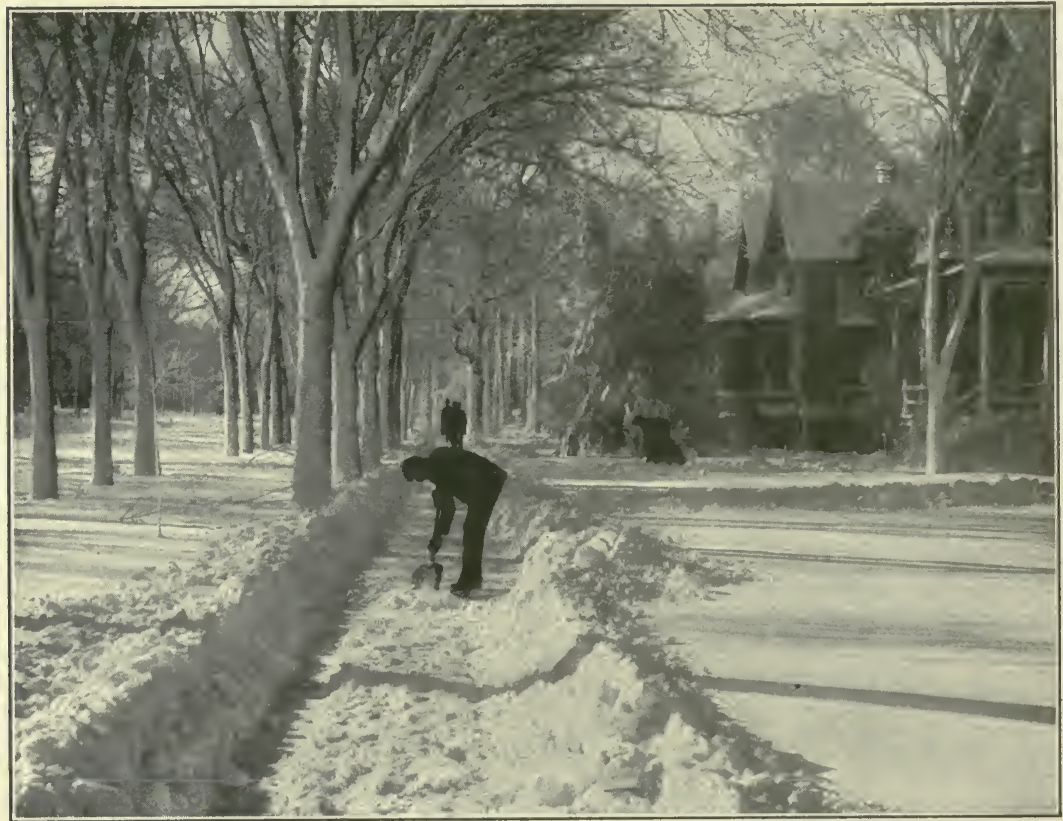

The beautiful snow

If you like the winter season, tell why.

Describe any place where you have seen snow piled up.

Of what use is snow to the roots of plants?

In what previous poem is snow spoken of as "bedclothes"?

What did the grass call the snow in the poem on page 38 ? 
"Whene'er a snowflake leaves the sky,

It turns and turns to say 'good-by,'

'Good-by, dear cloud, so cool and gray,'

Then lightly travels on its way."

Mention sports that you enjoy when the snow comes.

If you ever went coasting, tell about it.

How do you make a snow fort?

If you ever made a snow man, tell about it.

Which of these sports do you like best?

Mention places where much snow falls.

Tell about the weather in such places.

Why does snow never fall in some places?

Make pictures showing how some people use snow in housebuilding.

\section{Lesson 68}

\section{SNOWFLAKES}

IF we could travel up to the clouds we should 1 find, as we came into a freezing atmosphere, the particles of vapor being built up into tiny solid crystals of snow.

If you go out after a snowstorm and look carefully you will see that the snowflakes are not mere lumps of frozen water, but beautiful six-pointed crystal stars. The snow-stars are so white and pure that when we want to speak of anything 
being spotlessly white we say that it is "white as snow.". Some of these crystals are flat slabs with six sides. Others are stars with six rods or spikes springing from the center. Others have each of the six spikes formed like a delicate fern. Thousands of different forms of snowflakes have been found, yet they are all on the same plan. They all have six sides or six points. They are all made dazzlingly white by the reflection of the light from the faces of the crystals and the tiny air bubbles within them.

If you hold some snow in your hand it soon melts, and you have only a little water left. The crystals are all gone and the air bubbles are set free. Nothing is left to act as looking-glasses to reflect the light.

- Adapted from Arabella Buckley.

Look for crystals in the snow. Do you find many different forms? Count the faces or points.

Place a crystal on your sleeve or mitten and see it sparkle as the faces reflect the light.

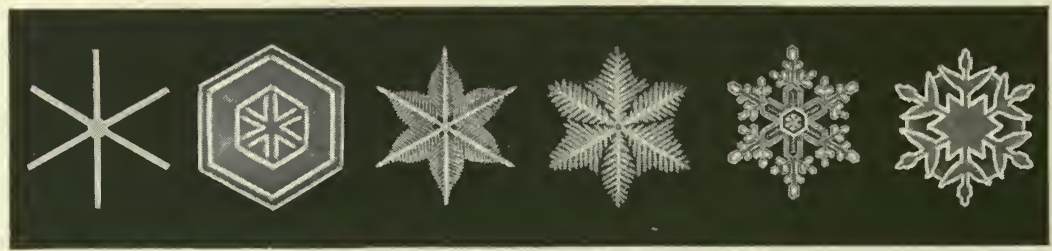

Six forms of snow crystals 
Make a few drawings of the snow crystals that you find.

Write a description of a snowstorm that you have seen.

Out of the bosom of the air,

Out of the cloud-folds of his garments shaken,

Over the woodlands brown and bare,

Over the harvest-fields forsaken,

Silent, and soft, and slow

Descends the snow.

- Henry W. Longfellow.

\section{Lesson 69}

\section{A WONDERFUL WEAVER}

THERE'S a wonderful weaver

1 High up in the air,

And he weaves a white mantle

For cold earth to wear.

With the wind for his shuttle,

The cloud for his loom,

How he weaves, how he weaves.

In the light, in the gloom.

Oh, with finest of laces,

He decks bush and tree;

On the bare, flinty meadows

A cover lays he. 
Then a quaint cap he places

On pillar and post,

And he changes the pump

To a grim, silent ghost.

But this wonderful weaver

Grows weary at last;

And the shuttle lies idle

That once flew so fast.

Then the sun peeps abroad

On the work that is done;

And he smiles: "I'11 unravel

It all, just for fun."

- George Cooper.

Write three paragraphs about "A Wonderful Weaver."

In your first paragraph tell who you think he is, with what he works, and when he works.

In the second paragraph describe what he does.

In the last paragraph tell what happens to his work.

\section{Lesson 70}

\section{A PICTURE STUDY}

What do you see in this picture?

What tells you about the season?

Of what do the shadows te11?

Where is the tree that casts the long shadow across the foreground? What kind of trees do you see in the picture? 


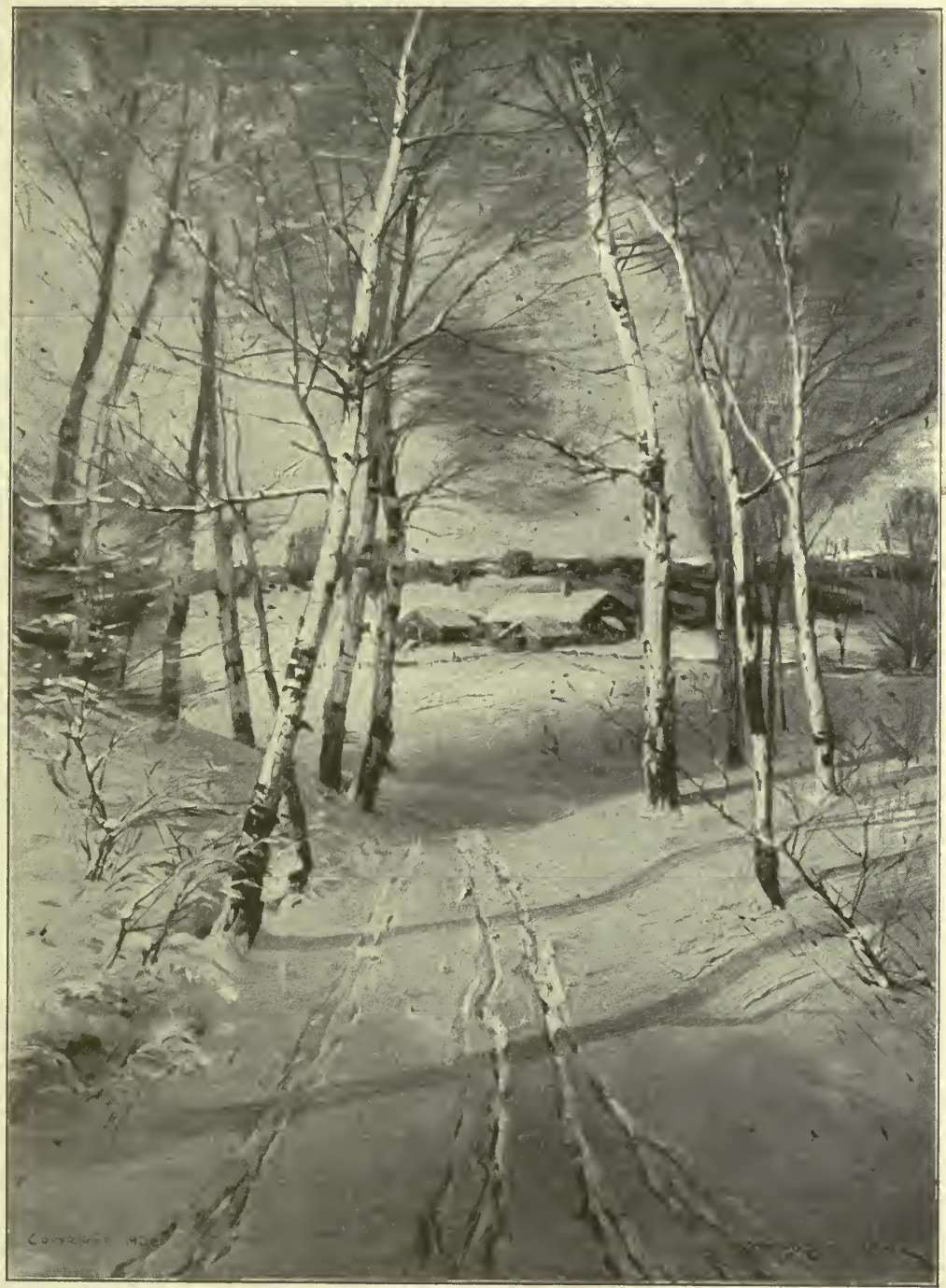

Copyrighted, 1900, by W. Scott Thurber, Chicago. Used by special permission. 


\section{II2 Language Through Nature}

Why do the trunks of some of the trees look so much whiter than others?

What do the tracks in the road tell you?

Tell what you notice about the width of the road.

In which direction does the road curve, and why can we not see it farther? Where do you think the road leads?

Why are the buildings so close together?

Tell what you notice about the shape and height of these buildings. Of what kind of life does such a home tell?

Why are none of the people who live in this home to be seen out of doors?

What do you see in the distance?

'Tell what you like best about this picture, and why.

\section{Lesson 7 I}

\section{SVEND SVENDSEN}

FAR to the north, and on the other side of the 1 sea, is a beautiful country called Norway. The mountains there are high. In the green valleys between the mountains are great forests of birch, and pine, and fir trees. In this far country there are also many lakes of sparkling water as blue as the sky above them.

Not many years ago a little boy whose name was Svend Svendsen lived in this land of Norway. This boy always played out of doors, and his eyes were quick to see the beautiful things about him. 
He saw the splendor of the morning sunshine upon the green hills, and the long purple shadows of the trees upon the freshly fallen snow. He liked to walk alone in the silvery moonlight, finding something beautiful everywhere he went.

One bright spring day a tall stranger with a bundle on his back came walking down the little valley in which Svend Svendsen lived. When he came to a cluster of white birches which grew by the side of a noisy brook he stopped, undid his bundle, set up his easel, and began to paint. Now this little clump of trees was one of the things that the boy loved most. He wanted to see what the man was doing, so he crept up behind and watched him at his work. As the picture grew before his beauty-loving eyes, how wonderful it all seemed to him! His heart beat fast with delight.

When the stranger had finished the picture he folded his easel and rose to go. Without a word Svend Svendsen picked up the artist's stool and followed him down the road. From that day the little boy and the tall stranger, who was one of the great artists of the North country, were friends, and the man taught the boy how to paint. Svendsen worked hard and studied long, till he became a 
great artist. He has painted many beautiful pictures, and in some of them you can see the morning sunshine on the green hills, or the long purple shadows upon the freshly fallen snow, or the gleam of silvery moonlight over the quiet earth, just as he saw them when a little boy in Norway years ago.

Among the most beautiful pictures which he has painted is the one you have been studying. In it you can see a little Norwegian farmhouse nestling in a quiet valley. Perhaps it was in just such a home as this that Svend Svendsen lived when a boy. Perhaps these are some of the white birches which grew near his home, and which he remembered and put into this picture.

Mr. Svendsen has left Norway and now lives in America, but his pictures tell us that he still loves his Norwegian home.

Tell this story in your own words.

Oh, now hurrah for sleds and skates!

A polar expedition waits

When school is done each day for me,

Off for the ice-bound arctic sea.

-From "Song for Winter," by Frank Dempster Sherman. 


\section{Lesson 72}

\section{ICE}

When winter comes what happens to the water in small lakes and streams? What do boys and girls then do?

Describe any places where you ever went skating or sliding on the ice. Mention other ways of traveling on the ice.

Tell what you know about ice-boats.

For what do we use ice during the hot summer weather?

From whom do we get it? How is ice kept from melting?

In what kinds of business is ice very necessary?

What do you know about the work of cutting and storing ice? What can you tell about artificial ice?

The ice is strong upon the creek, The wind has roses for the cheek, The snow is knee-deep all around, And earth with clear blue sky is crowned. -From "Song for Winter," by Frank Dempster Sherman.

SUGGESTED WORK

Fill a bottle with water, cork it and leave it out of doors on a cold night. Tell what happens, and why.

Put a little water $11 \mathrm{k}$ into a tin pail or pan and let it freeze solid. Explain what you see. Notice the ice around the edge of the pond. - If there are sticks or stones showing above the surface of the water, notice the way the ice forms around them.

From all these things tell whether you think water takes up more room or less when it is frozen. Can you find any crystals in the ice? 


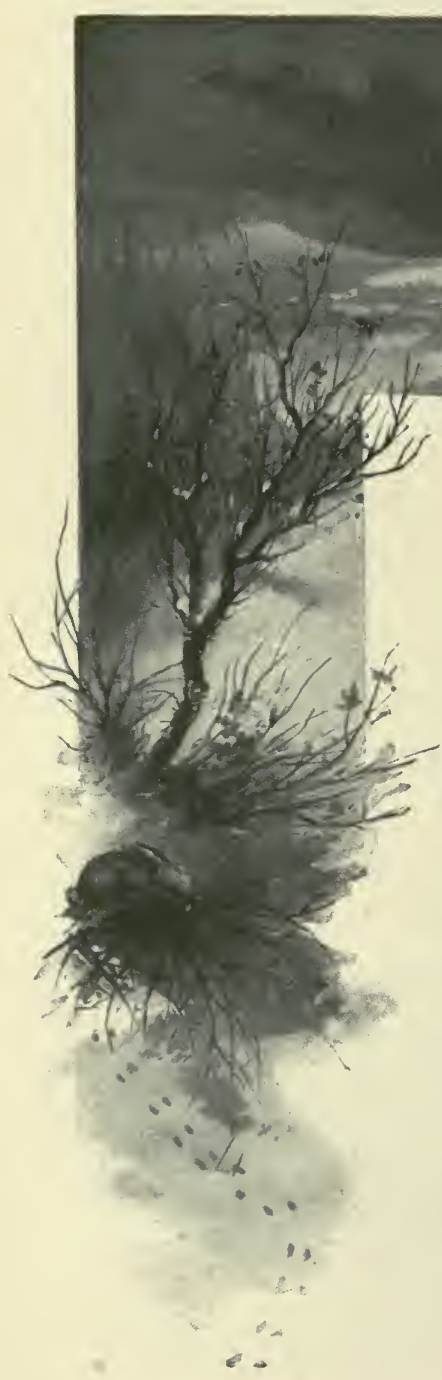

THE sun is gone down 1 And the moon's in the sky, But the sun will come up And the moon be laid by.

The flower is asleep, But it is not dead, When the morning shines It will lift its head.

When winter comes, It will die! no, no, It will only hide From the frost and snow. 
Sure is the summer,

Sure is the sun;

The night and the winter

Away they run.

- George Macdonald.

Copy this poem, placing all marks of punctuation carefuliy.

Remember that the first word of every line of poetry begins with a capital letter.

Learn the poem.

- What is the meaning of the contraction in the first stanza?

If you like this poem, tell why.

What have you learned in previous lessons how plants live when covered by the snow?

Tell about the length of day at this season.

How do you know that there is a difference in the length of day?

What causes night and winter to "run away"?

Why are we glad when the days begin to grow longer again?

Draw pictures which are suggested by this poem.

\section{Lesson 74}

\section{THE FIRST CHRISTMAS DAY}

"There's a song in the air!

There's a star in the sky!

There's a mother's deep prayer,

And a baby's low cry!

And the star rains its fire while the Beautiful sing, For the manger of Bethlehem cradles a King!" 
A LONG, long time ago people became unhappy A when the days grew short and dark and cold. They saw that plants stopped growing, that animals crept into hiding places, and that the sky was dark and gloomy. There was little they could do, and they became anxious and afraid.

But when the days grew longer and full of warmth and light, the people lost their fear. Animals came from their hiding places, birds sang, the earth was beautiful with growing plants, and the land was full of plenty. Then the people were busy and happy, and feasted, and gave each other gifts to show their joy at the returning light.

After many years there came a night when some shepherds, watching their flocks on a hillside, heard a new message which was for all the world. They saw a wonderful light in the sky, and heard a song not heard before on earth.

“" What means that star,' the shepherds said,

'That brightens through the rocky glen?'

And angels, answering overhead,

Sang, 'Peace on earth, good-will to men!' "

They were told that a child was born who should bring peace and good-will unto the world. Then, leaving their sheep, they sought for this child, and 
when they had found him they went and told others the good news.

When this child became a man he taught people to be kind and gentle and loving. Their hearts became full of light and gladness, and darkness no longer made them afraid.

This great teacher was called "The Light of the World," and on his birthday people began to give each other gifts and greetings in token of their gladness and goodwill. Now this birth-

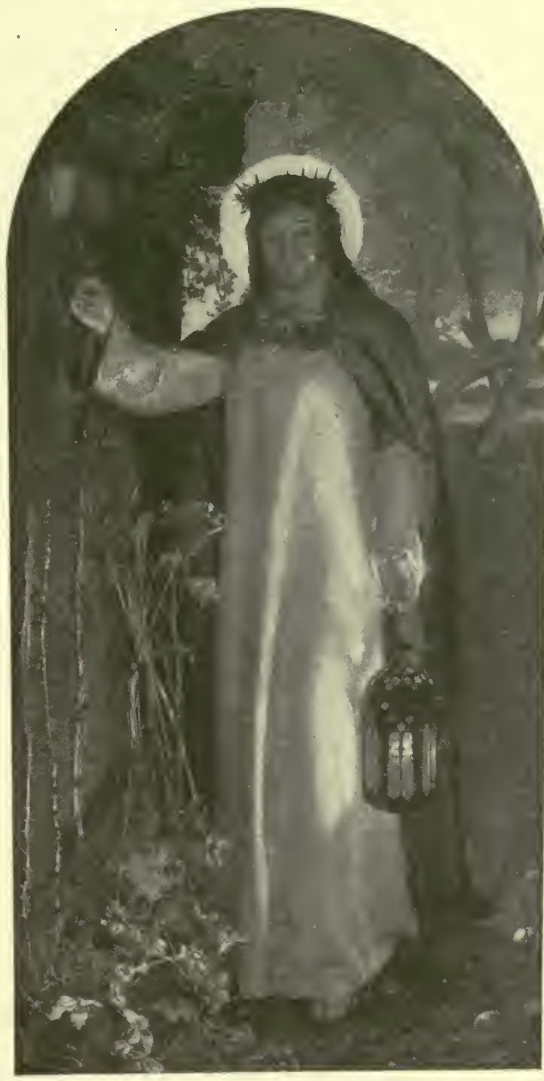

From a painting by Holman Hunt "THE LIGHT OF THE WORLD" day is kept by many people and in many lands.

Tell how we celebrate Christmas in this country. How are you going to make some one happy on this Christmas day? 


\section{Lesson 75}

\section{THE FIRST CHRISTMAS TREE}

$\mathrm{N}$ a quiet glade in the depths of a northern forest 1 was once gathered a strange company. It was night, but the people could be plainly seen by the light of an immense fire that burned in their midst. There were warriors in armor, aged men in fur mantles, women in robes of white, and little children in garments of lamb's wool. Their faces told of sorrow and fear. Their harvests had failed; there was sickness among them which none could cure; their warriors had been beaten in battle; and the days had grown cold and short. They believed that all this trouble had come upon them because the power they worshiped was angry. They thought this God would be pleased, and his favor be won again, by offering him a sacrifice. For this purpose they had gathered under a great oak, which was their sacred tree.

While they were preparing for this sacrifice a little band of men suddenly appeared, and everyone paused to ask what errand brought them there. The leader of the band sprang upon their altar 
and told them that he had come to teach them a new worship. They need no longer fear darkness nor offer sacrifices of blood. He would teach them, as he had been taught, a better way. They listened to him gladly and accepted his message with rejoicing.

He cut down the dark oak tree that stood for the Power they feared, and taking a young fir tree that stood straight and green, with its top pointing to the stars, he said, "Here is the living tree; it shall be the sign of your new worship. See how it points to the sky. Let us take it to your chieftain's hall."

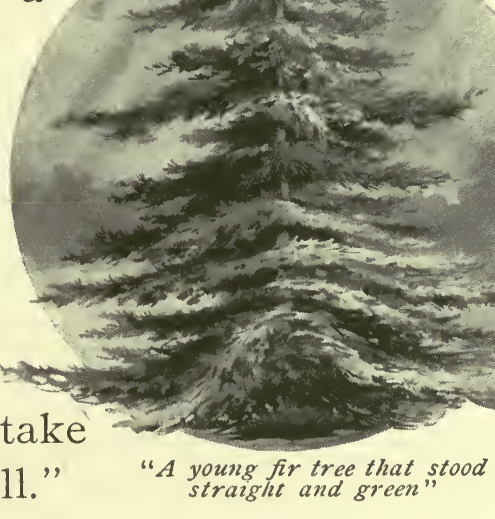

So they carried the little tree in joyful procession and set it in the midst of the chieftain's great hall. They kindled lights among its branches, and as its sweet odor filled the house they listened while the stranger told them of the first Christmas, and of the message of peace on earth and good-will to men. 
Now, in homes in many lands, children gather about green fir trees at Christmas time, and with good-will and gladness listen while the story of the first Christmas is told again.

-Adapted from "The First Christmas Tree," by Henry van Dyke.

Tell the story of the first Christmas tree in your own words.

Tell what is put on your Christmas tree.

\section{Lesson 76}

\section{THE GIFT-BEARER}

Of what time does the picture on the opposite page tell?

From whom is a visit expected?

Describe the visitor and tell how he travels.

What will he bring?

Why are the stockings hanging near the fireplace?

If you have ever tried to help Santa Claus by making a gift for some one, you may tell about it.

Make cuttings of things which you think the children, whose stockings you see in the picture, would like to have Santa Claus bring them.

Write a letter to your father or mother telling what you would like to have Santa Claus bring you.

Arrange and punctuate carefully.

Put the letter into an envelope and address it correctly. 


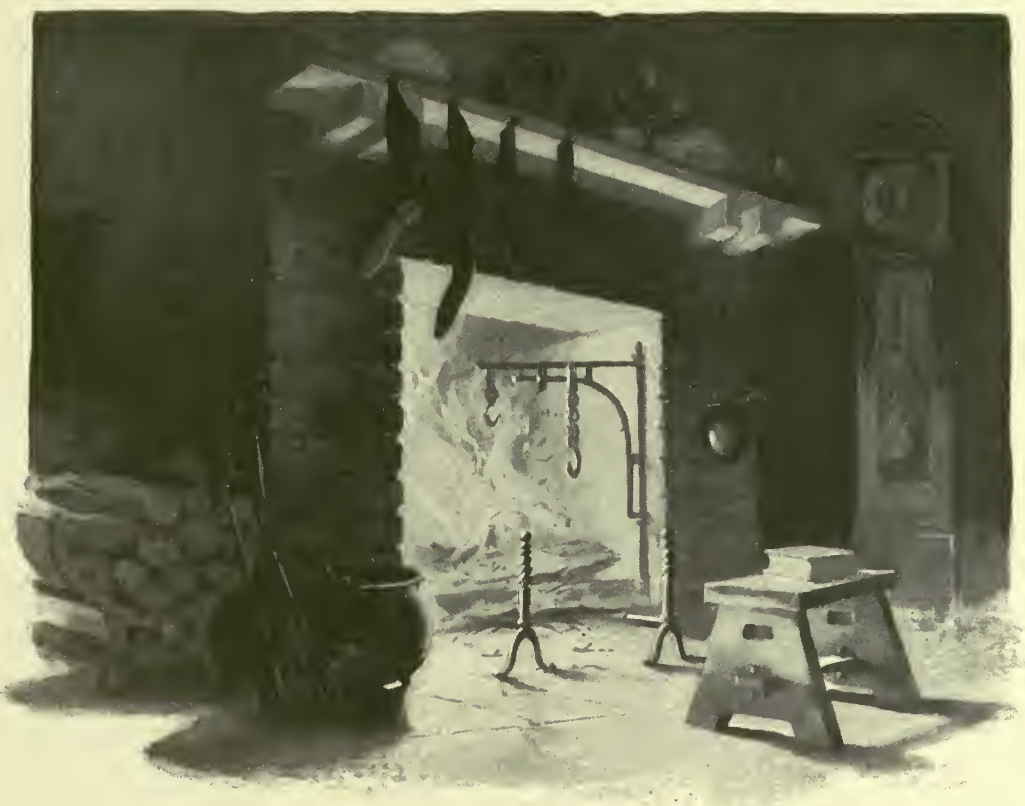

"The night before Christmas"

\section{Lesson 77}

\section{ANOTHER GIFT-BEARER}

IN far-off Russia the children think that their 1 gifts are brought by a little old woman, Baboushka. This is the story they tell about her.

Long, long ago an old woman was cleaning her house when she saw approaching three strangelooking men. She asked them where they were 
going. They told her they were seeking a wonderful child of whose birth they had heard. They had beautiful gifts for this child and asked the old woman to go with them and offer her gifts, too. She said she would do so if they would wait until she finished her cleaning. But they answered, "We may not wait; we follow a star."

After they had gone she kept thinking of the child and wished she had left her work. But the men could no longer be seen, and though she tried she could not find the way to the place of which they had told her.

Since then, each year as the day returns, the little old woman goes through all the land leaving gifts for every child. She hopes that among the children she may some day find the one she has sought so long.

Tell this story in your own words.

Describe any other Christmas customs of which you know.

Thy own wish, wish I thee in every place, The Christmas joy, the song, the feast, the cheer, Thine be the light of love in every face That looks on thee, to bless thy coming year. 


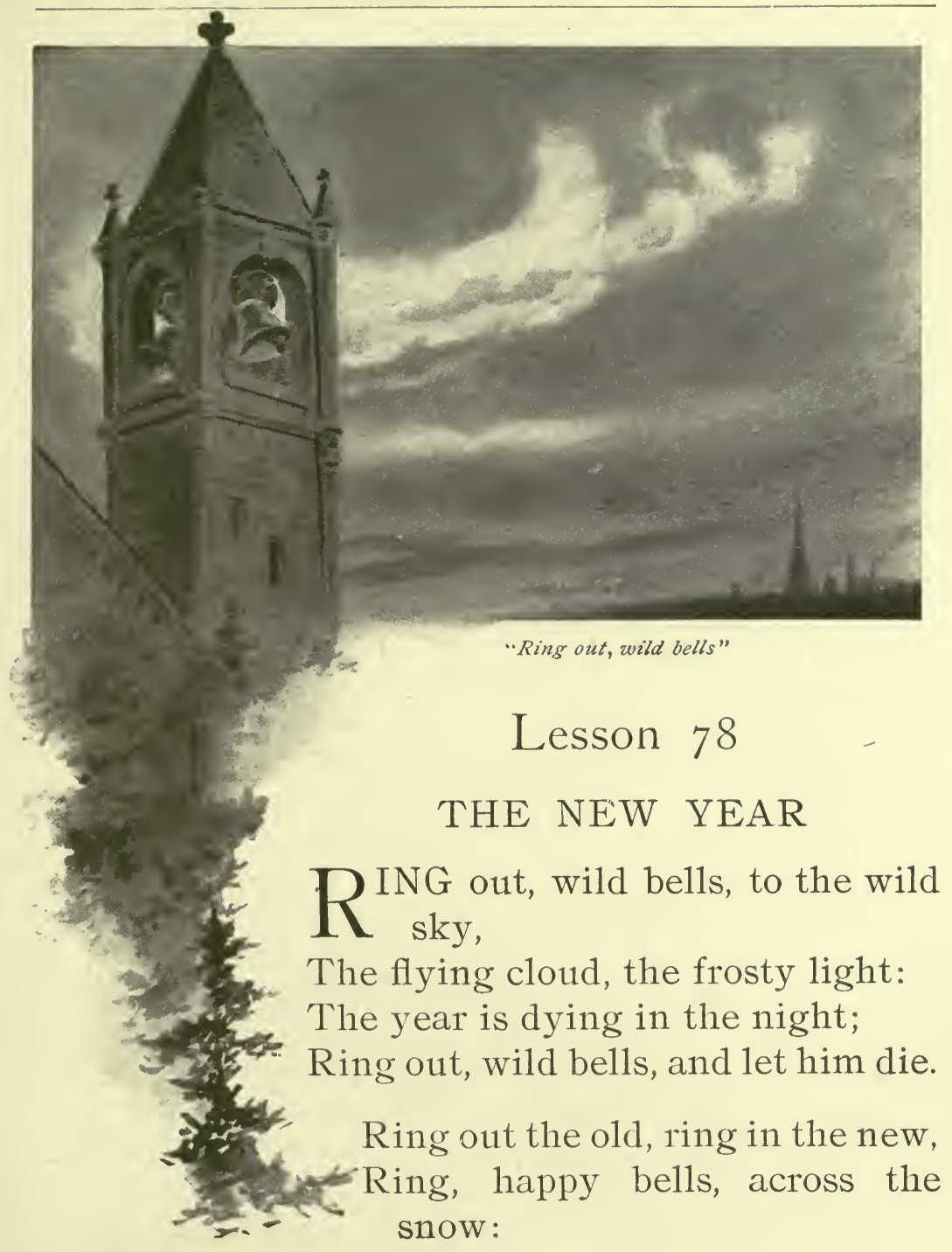




\section{I26 Language Through Nature}

The year is going, let him go;

Ring out the false, ring in the true.

- From "In Memoriam," by Alfred Lord Tennyson.

Who wrote these stanzas? What are they about?

Of what kind of night do they tell?

Why do the bells ring?

Tell why you think Tennyson calls them "happy bells."

What greeting do we give each other on the first morning of the new year?

Every day is a fresh beginning, Every morn is the world made new.

* $\quad * \quad * \quad *$

Only the new days are our own;

To-day is ours and to-day alone.

- Susan Coolidge.

\section{Lesson 79}

REVIEW OF THINGS TO REMEMBER WHEN WRITING

Tell what you have learned about the uses of capital letters. When should a question mark be used?

Tell what you know about the use of the period.

How is a word that shows ownership written?

What do the following parts of a letter tell. The heading? The date? The salutation? The signature?

Where should the first line of a paragraph begin? 
Write a letter to your teacher telling how you spent Christmas Day, and also what you enjoyed most during your vacation.

Be careful in regard to arrangement, in the use of capital letters, and in punctuation.

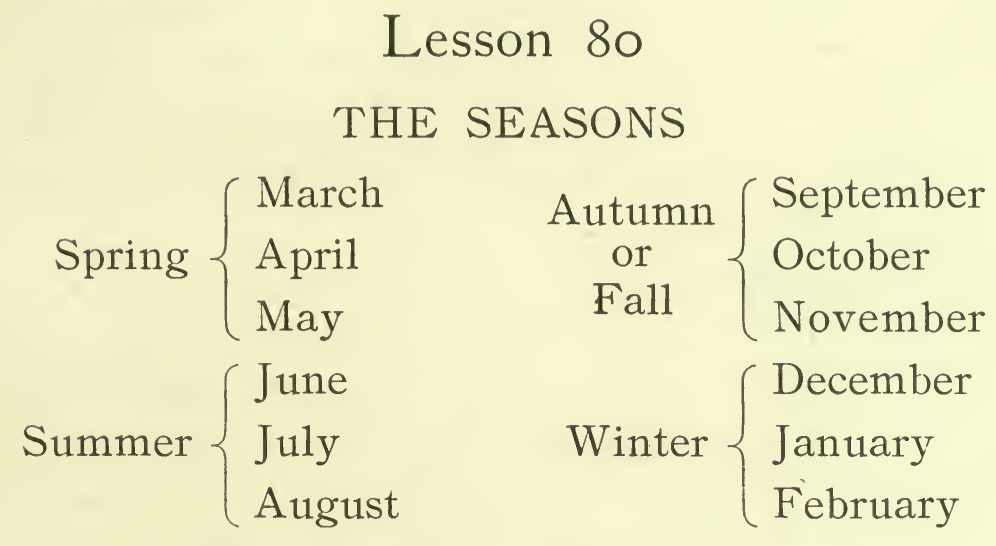

“'Spring, summer, autumn, winter,

All are beautiful and dear.

Spring, summer, autumn, winter,

Make a glad and varied year."

Write a paragraph telling about the division of the ycar into seasons, and naming the months in each season.

Write a paragraph about each season, telling in each some of the following things:

What you like best about it.

Some kind of work that is done at that time.

The plays or games you like best in each season.

Some holiday in each season.

Make a summary of your weather records for December. 


\section{Lesson 8 I \\ TELLING TIME}

KATE sat in her father's great armchair. She

K was all alone and the house seemed very still.

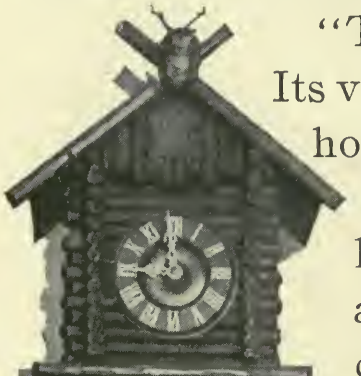

“Tick-tock, tick-tock," said the clock.

Its voice seemed very loud in the quiet house.

Kate looked at the clock and listened to its steady ticking for awhile; then she said aloud: "We could not do without a clock. It tells us when it is time to get up; it tells us when it is time to go to school; it tells us when to eat dinner. What would people do without clocks?" "Tick-tock, tick-tock," answered the clock. "Long ago people had no clocks, my dear little Kate."

"Why," said Kate, "how did they tell time then?"

"Oh," said the clock, "they had many

" Ticktock, ticktock, said the clock' 
"How could they measure time by shadows?" asked Kate in surprise.

" I'11 tell you," said the clock, " and then you can do it yourself. On the next sunny morning set a stick in the ground. Watch its shadow. Notice in which direction the shadow points and how long it is in the early morning. Look again in the forenoon and again at noon. See in which direction the shadow points in the afternoon and notice its length as night comes on. The shadow-stick was one way of telling time. Then some one made a sundial."

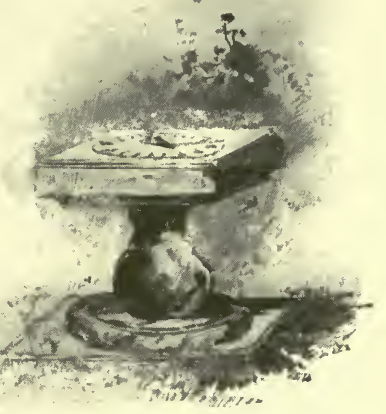

A sundial

" Please tell me about that," said Kate.

"Well," said the clock, "a sundial looks somewhat like a small square table made of stone or wood with a three-cornered piece of metal standing in the center. On the table top, or dial, there were figures showing the length of the shadow which this piece of metal cast at different hours of the day."

“That was a very nice way," said Kate, “only I don't see how people could tell time by the shadowstick or sundial on cloudy days or at night." 
“They couldn't," said the clock, "so some one invented the water clock. With this, time was measured by the flowing of water through a smal1 opening in a globe or tube. Then the hourglass was made. In it sand was used instead of water."

"Oh," said Kate, "I've seen an hourglass. Grandma has one. She often lets me use it."

"Sometimes people forget to turn the hourglass over," said the clock, "and then they lose track of the time. But about a thousand years ago a great king invented a way of telling time by candles."

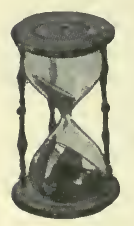

"Oh, yes, I have read about that," cried Kate; "that was King Alfred. I think his way was very good, indeed."

$\underset{\substack{\text { An hour } \\ \text { glass }}}{ }$ made the first clock, and I think that is the best way of all; don't you?"

What word in the first sentence of this story shows ownership?

Find examples of divided quotations in this story, and what is the method of punctuating them?

What contractions do you find, and what does each mean?

You will find words in this story, such as shadow-stick, which are made by putting two words together.

Words made by putting two words together are called compound words. The parts of a compound word are connected by a hyphen. 
Of what other use of the hyphen do you know? Find an example of such use in this story.

Write this story in your own words.

Use capital letters correctly in the title.

If you use the words $I$ or $O$, write them in capital letters.

Use quotation marks, hyphen, and all other necessary punctuation marks correctly.

Arrange your story in paragraphs.

"Take care of the minutes; they come and are gone; Yet in each there is space for some good to be done. Our time is a talent we hold from above; May each hour have us richer in wisdom and love!"

\section{SUGGESTED WORK}

I. Fasten an upright piece of wood or cardboard to a foundation. Place this in the window so that the upright casts a shadow, and mark the place where the shadow falls at a certain hour. With the stick in the same position repeat this each day and see if the shadow falls at the same place and hour.

Do you think this is a good way to tell time?

2. Take a large bottle, fill it with water and put in a tight cork. Through the cork make a small hole so that the water will slowly drop out when the bottle is inverted or held upside down. Remove the top and bottom of a chalk box and make a hole in one end, into which the neck of the inverted bottle may be put. Place an empty cup under the cork and see how much water drops into it in one hour. Measure the water that the bottle will hold to see how many such quantities it contains.

How many hours of time will this measure?

3. Take two empty ink or mucilage bottles; fit them with corks. In the center of each cork make a small hole. See that the corks are even with the tops of the bottles. Put a handful of fine dry sand into one bottle. Invert it and see how much sand runs out in a minute. Put this quantity into the second bottle and empty all the sand out of the first one. Invert one bottle over the other so that the holes in the corks are opposite each other and fasten the necks together. Sealing wax may be used for this. See if you can use this to measure time.

How could you change it so that it would measure five minutes?

4. Measure a new candle. Light it and let it burn for one hour. At the end of the hour measure it again to see how much has burned away. How many hours could this candle measure? Mark it by notches or bands of colored thread to show the number of hours. 


\section{I32 Language Through Nature}

\section{Lesson 82 \\ THE CLOCK}

Mention the important parts of a clock and tell the use of each part. Tell about some of the places in which you have seen clocks used.

What do we call the "clocks" which we carry in our pockets?

Tell of all the ways in which you think clocks are better for telling time than other ways about which you know.

Make a design for a clock.

\section{Lesson 83 AURORA A Greek Story}

U URORA, the goddess of the dawn, opened the - gates of day. As she flew through the air, dressed in filmy garments of rainbow hues, the dark clouds of night vanished and the east was filled with a rosy light. The birds woke to greet her with their glad morning songs, and she scattered sweet flowers and glittering dewdrops over the sleeping earth. Behind her came her brother, the bright and beautiful sun-god, Apollo. He sat in his splendid golden chariot, guiding his fiery horses across the sky. Around him, hand in hand, 
danced a group of happy maidens. They were the hours bringing to mortals the joys and duties of the day. Above them all, the glorious morning star lighted the way.

Writc this story in your own words.

Arrange the story in four paragraphs, as follows: In the first paragraph describe Aurora and tell what she brought; in the second paragraph tell what happened on earth at her coming; in the next paragraph tell who followed her and what he was doing; and in the last paragraph tell who accompanied Apollo and what they brought.

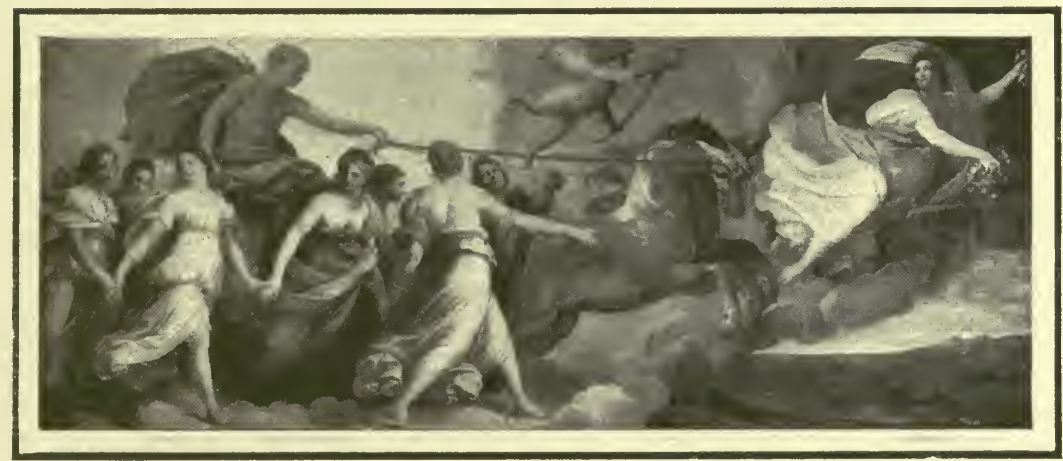

AURORA

From a painting by Guido Reni

\section{Lesson 84}

\section{A PICTURE STUDY}

Study this picture and tell what you think the different figures represent.

How do you think this company is moving?

Tell why you think so. 


\section{I34 Language Through Nature}

Is the picture one of sorrow or of joy? How is this shown?

What do you think the artist thought about the dawning of a day? How has he shown this?

What do you like best in this picture?

\section{Lesson 85 \\ GUIDO RENI}

M ORE than three hundred years ago, in the 1 quaint old city of Bologna, a beautiful darkeyed baby was born. This baby was Guido Reni. His father was a musician, and often, as he looked with proud, loving eyes at his little son, he exclaimed, "The boy has the face of an angel. We must make a musician of him." When Guido grew old enough his father taught him to play upon the flute, the harpsichord, and other instruments, and gave him lessons in singing.

The boy sang sweetly and played well, but there was something he loved far better than making music, and that was making pictures. He sketched figures on scraps of paper, and when by his father's orders paper was kept from him, he drew pictures on the walls of the house and in the dust that lay thick upon the pavement of the old courtyard of his home. 
This made Guido's father very angry, for he had determined that his son should be a great musician, and the father's anger made the boy very unhappy.

However, one day a great artist chanced to see some of the boy's sketches and persuaded the father to allow Guido to take lessons in drawing and painting. The boy worked hard and learned rapidly. He made such progress that when he was only thirteen years old his teacher often called upon him to help the other students in their work.

Guido Reni's dearest wish was realized-he became an artist-but he was never a great artist. His best work was done while he was a young man. As he grew older he became so anxious to make money that he painted hastily and carelessly. He does not seem to have cared whether his pictures were good or bad so long as people bought them. These paintings of his later years are forgotten, but the pictures which Guido painted in the days when his heart was in his work remain and are as much admired to-day as they were more than three hundred years ago when the artist lived and worked.

The best known and most beautiful of Guido Reni's pictures is the "Aurora." He painted it upon the ceiling of a room in a palace in Rome. It 
can be seen there to-day full of life and glowing . with rich colors.

In this picture one sees a group of graceful, noble figures, and lovely happy faces. All the figures are full of action. Each one in the picture has his appointed work to do and is bringing some blessing to the people of earth. Every face and form expresses the joy which comes to those who work for the sake of others and rejoice in their work.

The loveliest of all the figures in this picture is Aurora, who, floating on the clouds before the mighty horses, scatters the darkness of night and brings to earth the beauty and gladness of the day.

Tell the story of Guido Reni and his work.

\section{Lesson 86}

\section{HIAWATHA'S SAILING}

" CIVE me of your bark, O Birch-tree!

Of your yellow bark, O Birch-tree!

Growing by the rushing river,

Tall and stately in the valley!

I a light canoe will build me,

Build a swift Cheemaun for sailing, 
That shall float upon the river,

Like a yellow leaf in Autumn,

Like a yellow water-lily! "Lay aside your cloak,

O Birch-tree!

Lay aside your whiteskin wrapper,

For the Summer-time is coming,

And the sun is warm in heaven,

And you need no whiteskin wrapper!"

Thus aloud cried Hiawatha

In the solitary forest.

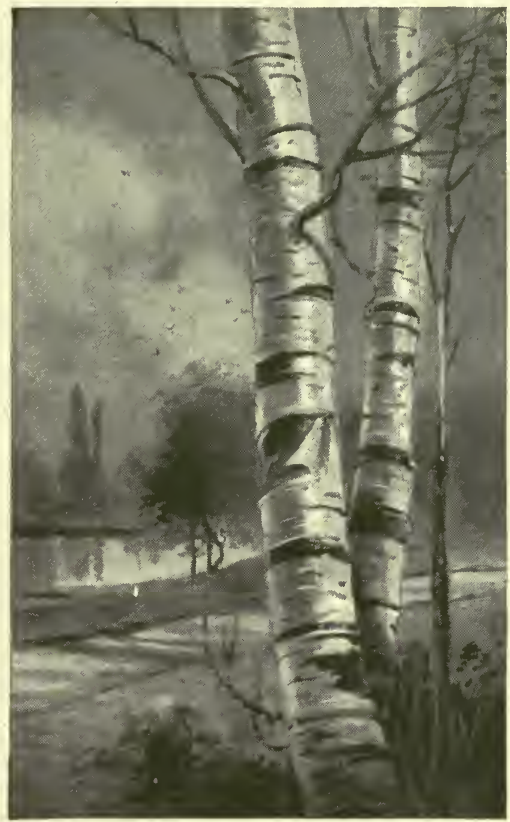

"O Birch-tree, tall and stately"

By the rushing Taquamenaw, When the birds were singing gayly,

In the Moon of Leaves were singing,

And the sun, from sleep awaking,

Started up and said, "Behold me!

Geezis, the great Sun, behold me!"

And the tree with all its branches

Rustled in the breeze of morning, 


\section{8 Language Through Nature}

Saying, with a sigh of patience, "Take my cloak, O Hiawatha!" With his knife the tree he girdled; Just beneath its lowest branches, Just above the roots, he cut it, Till the sap came oozing outward; Down the trunk, from top to bottom, Sheer he cleft the bark asunder, With a wooden wedge he raised it, Stripped it from the trunk unbroken.

* -From "Hiawatha," by Henry W. Longfellow.

In the first stanza Hiawatha speaks to the Birch-tree.

Find a place in this poem where some one is addressed or spoken to.

Notice that the words in which anyone is addressed are separated from the rest of the sentence by a comma.

Quote all that Hiawatha said to the Birch-tree.

Copy this quotation, being careful to use the comma correctly in cach case of direct address. Write the quotation that tells how the Birch-tree addressed Hiawatha; and write a paragraph telling in your own words how Hiawatha got the bark from the tree.

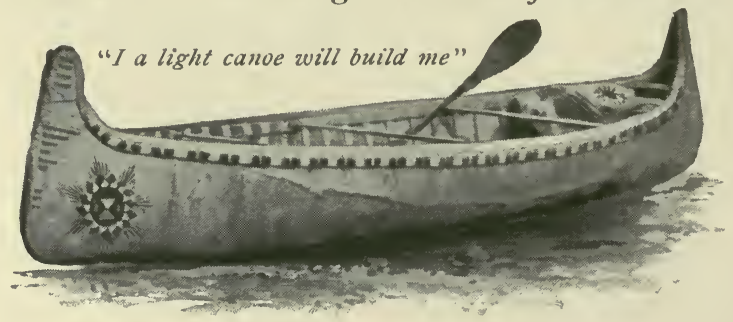




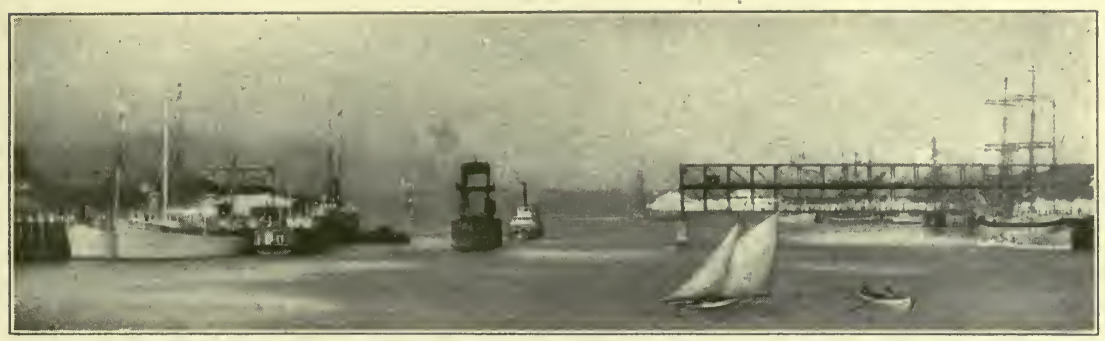

Uses of boats

\section{Lesson 87}

\section{WAYS OF TRAVELING}

Mention the different kinds of boats you have seen, and tell what gives motion to each. Which have the most speed?

Of what material were these boats built?

What do you know about the uses of boats?

Mention all the different vehicles in which you have seen people traveling on land, and tell by what each was moved.

How did the Pilgrims travel in their new country?

Tell how you think the Indians traveled on land.

Make pictures showing different ways of traveling on land.

Singing through the forests,

Rattling over ridges,

Shooting under arches,

Rumbling over bridges,

Whizzing through the mountains,

Buzzing o'er the vale,

Bless me! this is pleasant,

Riding on the rail! 


\section{0 \\ Language Through Nature}

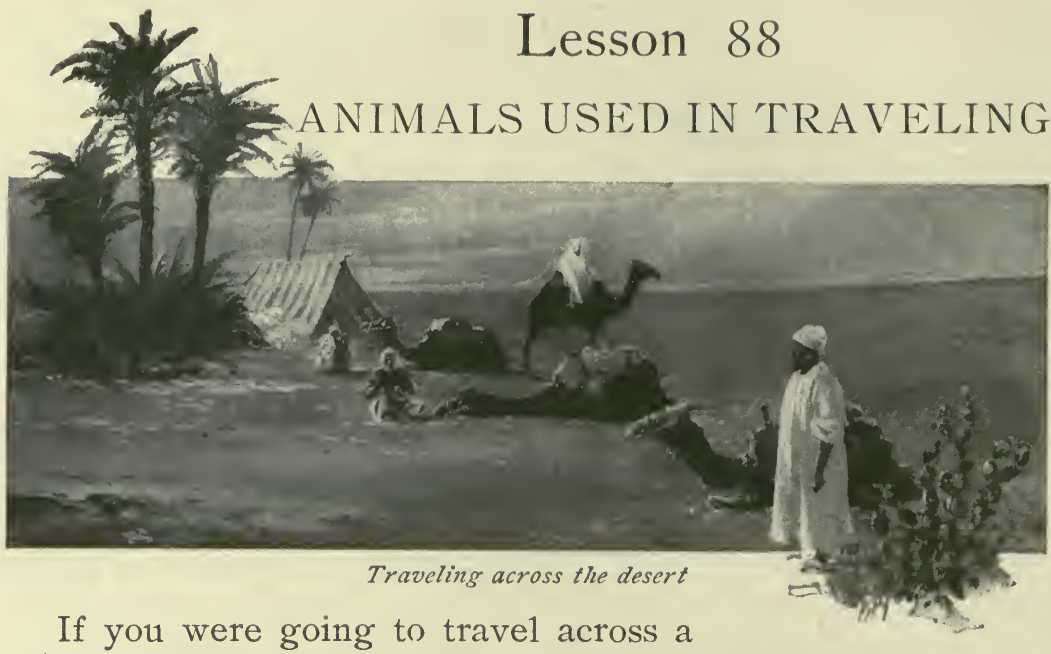

desert place, what animal would you choose to ride?

Tell why you would choose him.

How could you get upon this animal's back, and on what would you sit?

If you have seen this animal, tell where.

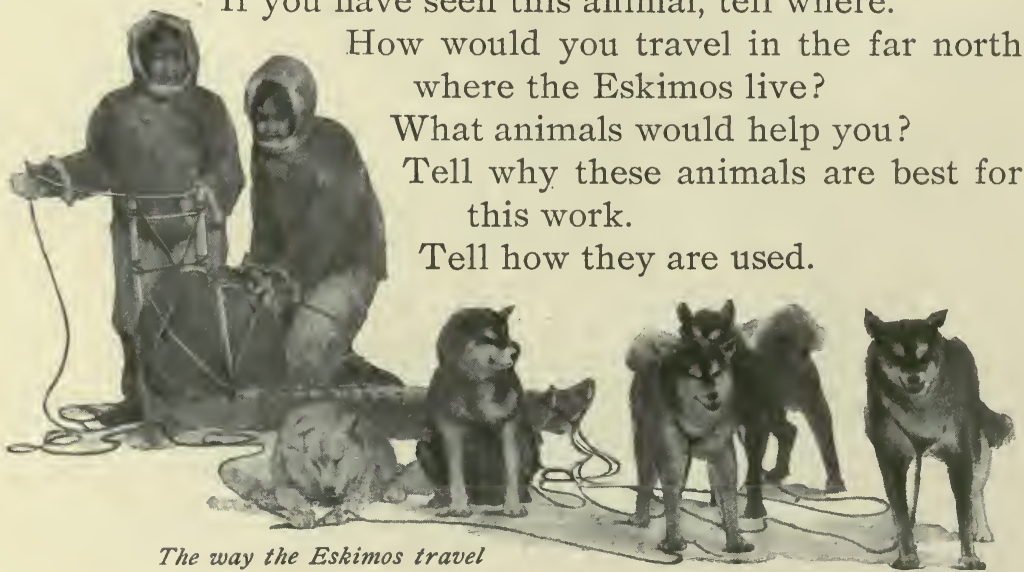




\section{Lesson 89}

\section{A USEFUL ANIMAL}

What animal do you most often see used to draw the vehicles in which people travel?

How is this animal fitted for such work? Tell how he is fitted to go swiftly on long journeys. Describe his feet.

Tell what men put on his feet and why this is done.

What do you know of this animal's food?

What care is needed for such an animal, and why?

What can you say of this animal's love for his master?

In what ways is this animal useful to man?

What other animals do you know about that are used to draw vehicles or carry burdens?

Write what you can about each of these animals.

Tell which you think most interesting. Why?

If you use words showing ownership or possession, remember. how such words are written.

Be careful to make your work correct in regard to capitals, punctuation, and paragraphs.

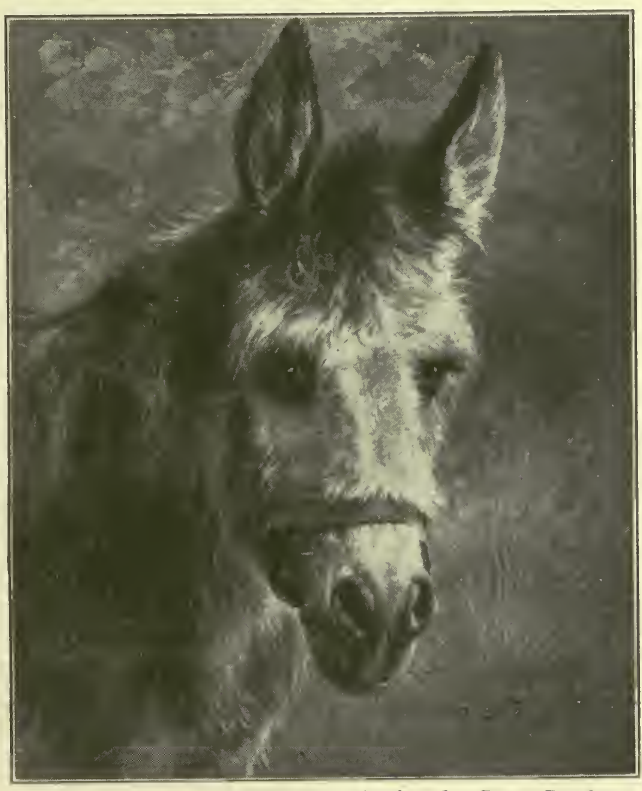

From a painting by Rosa Bonheur A DONKEY'S HEAD 


\section{Lesson 90 \\ A PICTURE STUDY}

Tell what you see in this picture.

What color are the horses?

What can you say of their size and strength?

Does the man look as if he lived in the city or the country?

How do you think he treats the horses?

Tell what you like best in this picture.

What do you think the artist saw in these horses that made him wish to paint a picture of them?

Tell what this picture is called, and give the artist's name.

\section{Lesson 9 I}

\section{DAGNAN-BOUVERET}

PASCAL Adolphe Dagnan-Bouveret is a French artist. When he was a boy he longed to become a painter of pictures, but his father said he must be a merchant. Pascal was in great trouble. He loved art, but had no money to pay for lessons in painting, and his father was angry with him for wishing to be an artist. Just then his grandfather, who loved him tenderly, offered to pay for the lessons, and so Pascal began to paint.

He became a famous artist, and has painted some fine pictures. "At the Watering Trough" 


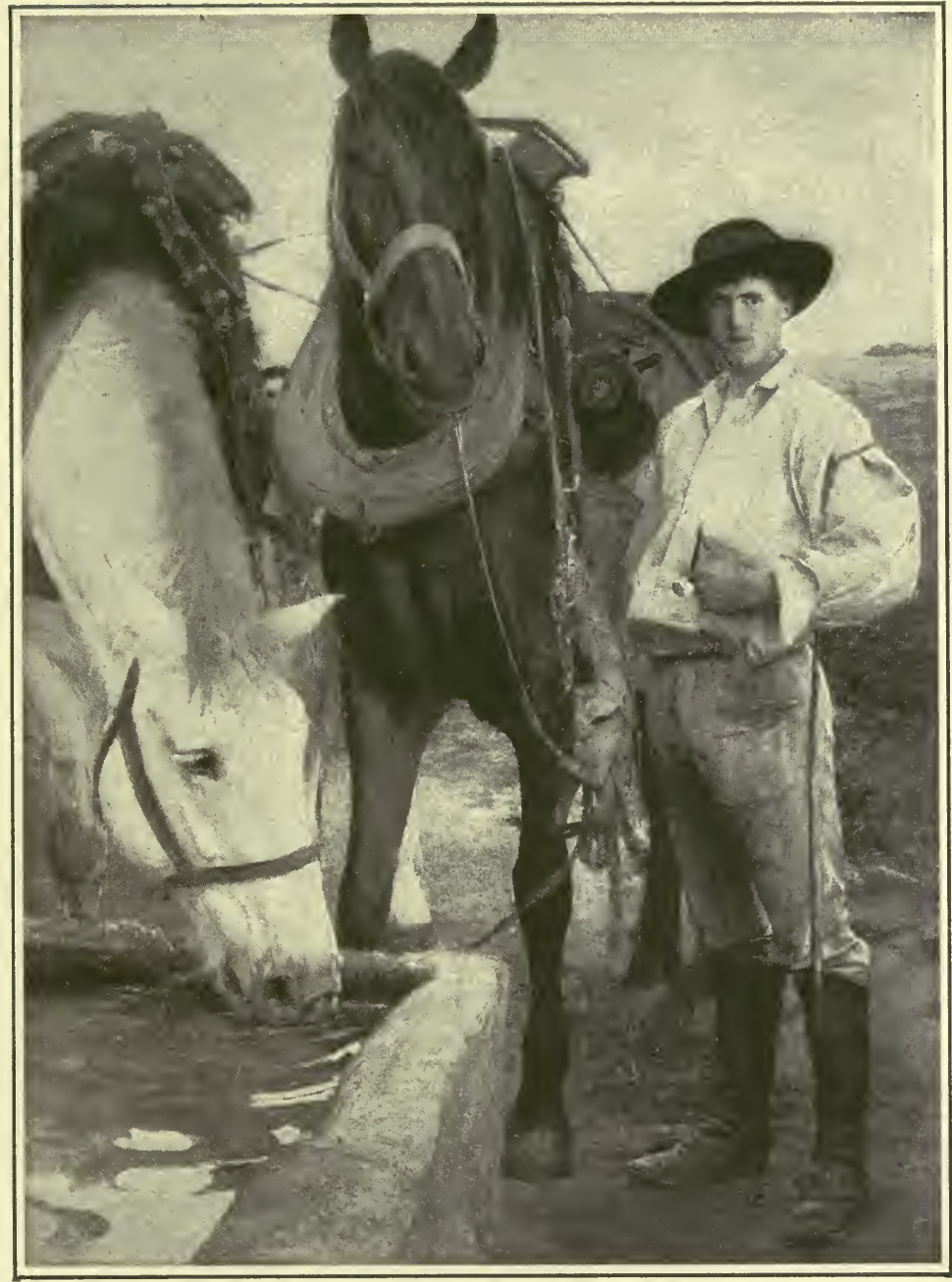

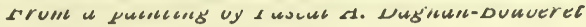
AT THE WATERING TROUGH 


\section{I44 Language Through Nature}

is a copy of one of his paintings. He painted this picture while he was visiting on a farm. One day he saw one of the farmer's men with two splendid horses at the watering trough. The artist admired the strength and beauty of these horses, and saw how proud the man seemed of them and how kind he was to them. He saw what a fine picture this group would make, and immediately began to paint it upon canvas. He worked upon it slowly and patiently for six months, but when finished it was worth painting.

Tell about Dagnan-Bouveret and his work.

\section{Lesson $9 \cdot 2$ \\ MONTHLY SUMMARY}

Make a summary of your weather records for January.

Paint or draw a picture showing the appearance of the landscape at this season.

Write a letter to your father telling him about what you have done this month.

What outdoor sports have you enjoyed most, and why?

Make your letter correct in form and arrangement.

January, bleak and drear,

First arrival of the year,

Named for Janus,- Janus who,

Fable says, has faces two.

- Frank Dempster Sherman. 


\section{Lesson 93}

\section{THE VILLAGE BLACKSMITH}

T NDER a spreading chestnut-tree The village smithy stands;

The smith, a mighty man is he,

With large and sinewy hands;

And the muscles of his brawny arms

Are strong as iron bands.

His hair is crisp, and black, and long,

His face is like the tan;

His brow is wet with honest sweat,

He earns whate'er he can, And looks the whole world in the face,

For he owes not any man.

Week in, week out, from morn till night,

You can hear his bellows blow;

You can hear him swing his heavy sledge,

With measured beat and slow,

Like a sexton ringing the village bell,

When the evening sun is low.

And children coming home from school

Look in at the open door; 
They love to see the flaming forge, And hear the bellows roar, And catch the burning sparks that fly Like chaff from a threshing-floor.

He goes on Sunday to the church, And sits among his boys;

He hears the parson pray and preach, He'hears his daughter's voice, Singing in the village choir, And it makes his heart rejoice.

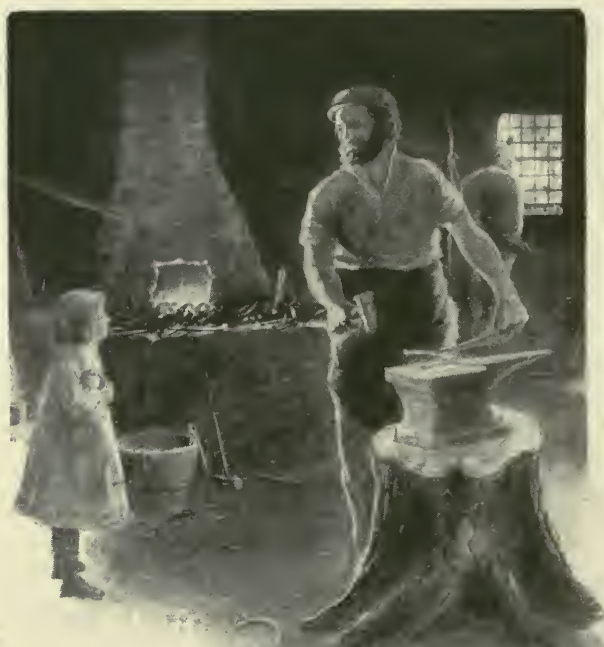


It sounds to him like her mother's voice, Singing in Paradise!

He needs must think of her once more, How in the grave she lies;

And with his hard, rough hand he wipes

A tear out of his eyes.

Toiling,-_rejoicing,-_sorrowing,

Onward through life he goes;

Each morning sees some task begin,

Each evening sees it close;

Something attempted, something done,

Has earned a night's repose.

Thanks, thanks to thee, my worthy friend,

For the lesson thou hast taught!

Thus at the flaming forge of life

Our fortunes must be wrought;

Thus on its sounding anvil shaped

Each burning deed and thought.

- Henry W. Longfellow.

Write the story of this pocm in your own words, letting each paragraph tell about one of the following topirs:

The blacksmith and his shop.

The blacksmith's work, and what the children like about it. What the blacksmith does on Sunday. 


\section{I48 Language Through Nature}

What you like about this man and his work.

What does the contraction in the second stanza mean?

Find the words in the poem that show possession.

If you write these words, be sure that you use the apostrophe and s.

\section{Lesson 94 \\ THE BLACKSMITH'S WORK}

If you have seen a blacksmith at work, you may tell about it.

What are some of the things a blacksmith makes?

Tell of what they are made.

For what purpose does the blacksmith use "the flaming forge"? Of what use is the bellows?

Tell what you can about the anvil.

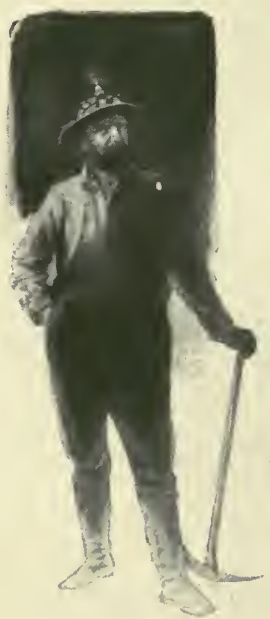

$A$ miner
For what does he use the sledge?

Make a picture of a blacksmith at work.

Make cuttings of some of the things which a blacksmith makes.

\section{Lesson 95 IRON}

Iron is seldom found alone, but combined with other substances.

This combination is called iron ore.

Tell what you can about iron ore, and where it is found.

Tell about the tools the miner uses. 
Why does he take a lamp, and where does he carry it?

How do you think the iron ore is carried out of the mine?

The iron must be separated from the other substances, and this is done either by crushing the ore, or putting it in great furnaces and melting out the iron.

Tell why people go to so much trouble to get iron.

Sing a song of iron in a mine so deep, Where the mighty mountains guarding watch doth keep.

Down must go the miner in the ground so damp, Each one with his pickax and his tiny lamp.

-From "Songs of the Child World," by Jessie L. Gaynor.

\section{Lesson 96 \\ USES OF IRON}

Mention some things that you see every day in the schoolroom, in the street, and at home, that are made of iron.

Give reasons for using iron for these things.

Tell what you know about the changes which take place in hard, cold iron when it is put into the forge furnace.

What do you know about the hammering or molding of iron.

Write a paragraph on each of the following topics:

Where iron is found and how gotten.

Uses of iron.

Qualities of iron that make it better than other materials for these uses. 


\section{Lesson 97}

\section{VULCAN THE SMITH}

GES ago people dwelt at the foot of Mount A Olympus in the beautiful land of Greece. At times strange clanging sounds came ringing down the mountain side and a ruddy glow lit up the midnight sky. Then the people whispered to each other, saying, "Vulcan the Smith is at work." Sometimes a shepherd, leading up his flock of sheep or goats to eat the sweet mountain grass, caught a glimpse of Vulcan at his anvil, and returning would tell his neighbors of the mysterious smith whose forge was hidden among the rocks. "Vulcan is terrible to look upon," so the shepherd would say to his wondering friends. "He is very ugly and misshapen and lame, but he is strong, and his mighty arm swings the big hammer as if it were a toy, and as for the things that he makes, they are too curious and beautiful to be described."

The people listened and longed to know more of Vulcan and his work, but feared him too much to climb the mountain to see him at his forge.

Vulcan was ugly and misshapen and lame, just 
as the shepherd said, but he loved his work, and in his lonely cave far above the dwellings of men he worked at forge and anvil, shaping the shining metals into things of marvelous beauty. He made spears and shields and suits of glittering armor for warriors. He made golden necklaces to hang about the necks of queens, and massive cups of silver from which kings drank at their feasts. Once he wrought two great dogs of gold and silver. They were so lifelike and fierce-looking that they were set to guard the gateway of the palace of a king.

High upon the mountain Vulcan built a stately palace for himself. It was made of hammered copper, with doors of finest gold and silver. When the clouds that always hung about Mount Olympus parted, the people on the plains below saw the palace walls flashing in the sunlight and marveled at its splendor. The fame of its builder spread throughoụt the land, and all the people wondered at the strength and skill of Vulcan the Smith.

Tell the story of Vulcan the Smith in your own words.

If you write the story, punctuate and paragraph carefully. 


\section{Lesson 98 \\ PRECIOUS METALS}

Tell why gold is called a precious metal.

Mention some ornamental things that are made of gold.

Name some useful things that are made of gold.

Tell about some other precious metal of which such things are made.

Give reasons for using these metals in such ways.

Tell what you can about where these metals are found, and how they are made fit for use.

Make drazeings of some beautiful things that you have seen or read of that were made of gold or silver.

\section{Lesson 99 \\ OTHER METALS}

Name the metals about which you have talked in the previous lessons.

Mention other metals that you have seen.

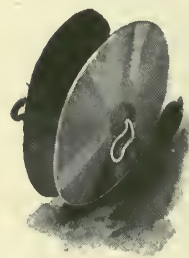

Brass cymbals

Tell what you can about each of these metals not previously spoken about, and for what each is used.

How do they compare in value with gold or silver?

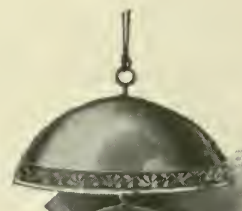

How do they compare in usefulness with iron? found, and how they are prepared for use. 


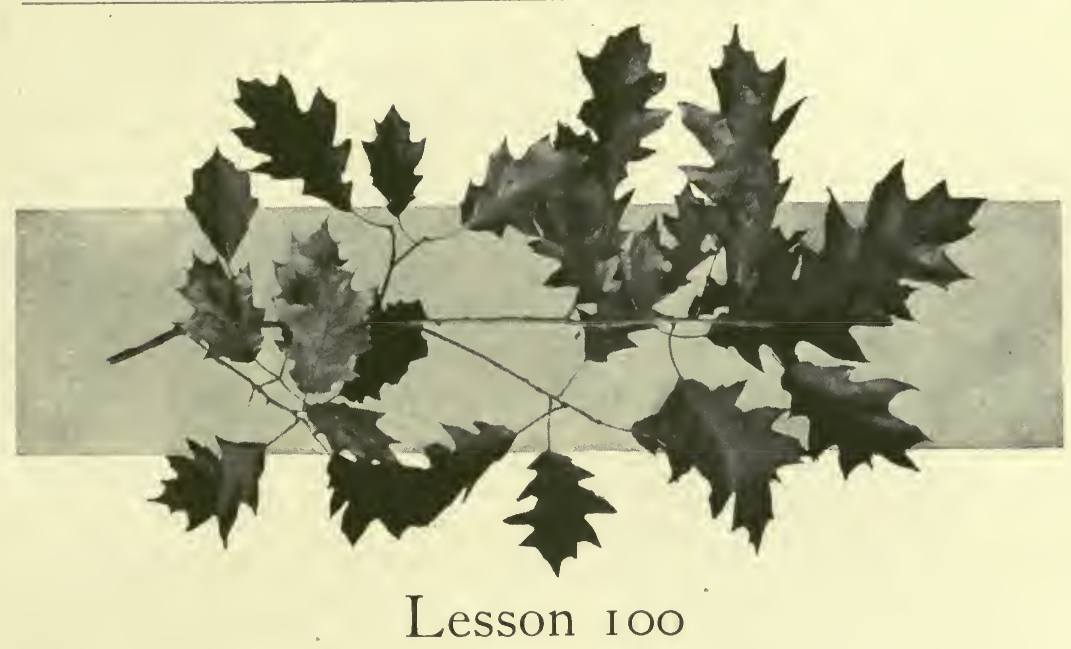

\section{THE GOLDEN TOUCH}

ONCE upon a time there lived a king whose name was Midas. King Midas possessed great riches, but he longed for more. One day he was told that any wish that he made would be granted, and he was very happy. He thoughtlessly asked that everything which he touched should be turned to gold.

This power was given him and he rejoiced. He picked up a pebble, it turned to gold. He broke a twig from an oak tree, it became gold in his hand. He plucked an apple from the bough, it too turned to gold at his touch. 
The king was overjoyed. He hurried home and ordered a splendid meal to be set before him. He sat down to eat, thinking that he was the most fortunate man in the world. But his joy quickly turned to sorrow. The dainty food before him became gold at his touch. The bread hardened in his hand. The wine became solid gold at the touch of his lips. The poor king was in despair.

"Must I starve to death?" he cried. "I cannot eat gold. Oh, that I were rid of this hateful gift!"

The one who had bestowed the gift upon him heard his cry and came in pity to him. "Go," said he to the king, "plunge into the river. It will take away this power that is now so hateful to you."

Midas hastened to the river. In he plunged and found to his great joy that the power of the golden touch had left him. It passed into the waters of the river, and from that day to this the sands along the river banks are as yellow as gold.

Ever after the sight of gold was hateful to Midas. Forsaking his splendid palace he dwelt in the country and became a lover of the beauties of Nature.

Tell this story in your own words. 


\section{Lesson IO I}

\section{ABRAHAM LINCOLN}

I $\mathrm{N}$ a log cabin built under green trees, and near a 1 singing brook, was born, on February i 2, I809, the baby boy who grew to be our great Abraham Lincoln. This cabin had but one room. There was no glass in the one little square window and no door in the doorway, but over both of these openings skins were sometimes hung to keep out the cold and wind. To the left of the doorway was a wide fireplace built of stones and clay, with the chimney built against

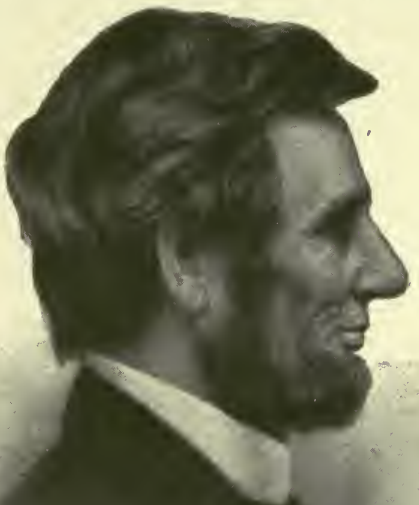
the outside of the house. There was no floor except the hard-packed earth. For furniture there were blocks of wood, a home-made bench, and a 
pole bedstead, while the bedding was the skins of animals and a homespun quilt.

In this lowly home in Kentucky the little boy Abraham Lincoln lived and grew until he was eight years old. His only playmate was his sister Sarah, two years older than himself, and though he had no toys such as most children have, he was a happy child. He caught fish in the clear brook, watched birds and squirrels in the tree-tops, and found many things to enjoy in the woods about his home. He was tall and strong for his age, and his father had taught him to swing an ax and shoot a gun, so that he felt quite brave and manly, and often helped his mother, who was a very busy woman. She kept the cabin clean, cooked their food, made their clothes from skins or from cloth which she spun and wove, and sometimes helped to take care of the garden. With all this work she kept a happy. heart and found time to tell the children stories she knew, and to teach little Abraham to read as soon as he was old enough to learn.

In the autumn after his eighth birthday the Lincoln family moved to Southern Indiana. In the story of Lincoln's life you may read of that hard journey, of the building of a new cabin home, of 
the death of the brave, patient mother, and of the lonely, uncomfortable days that followed. You may also read how at last a kindly woman came as a new mother to care for the neglected home and children, and you will be glad that she took such good care of the poorly dressed, homely little boy. Happier days agreed with him well, and at fifteen years of age he could run the swiftest, jump the highest, throw the farthest, split wood the best, and plow the deepest of any boy in his neighborhood. He was good-natured, obliging, and kind to every living thing, and so honest and true in all that he did that he was called "Honest Abe." All the time he had spent in school put together would not make more than a year, but he had read every good book he could get hold of, and he remembered and thought about what he had read.

Soon after Lincoln was fifteen years old he made up his mind to become a lawyer. He went on working, on the farm, on the river, in a store, or in the forest, earning what money he could to help his family, but reading and studying law in his spare time, and thinking as he worked.

Lincoln's family moved to Illinois when he was twenty-one years old, and as the years went by he 
became not only a great lawyer to whom people went when in trouble, but a good man whom everyone loved and trusted. When our country was in great danger he was chosen President, and by his

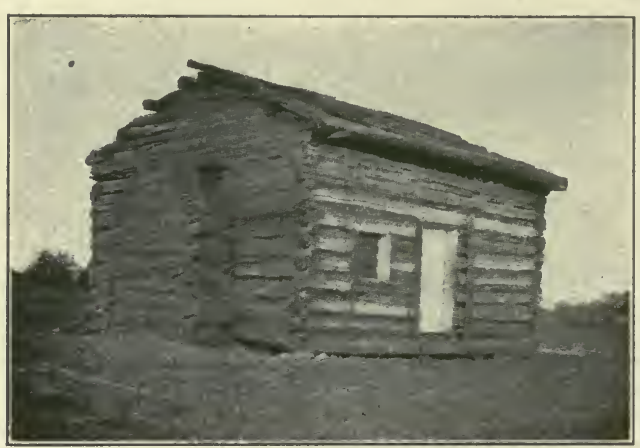

The log cabin in which Abraham Lincoln was born wise and unselfish leadership found a safe way out of the trouble and saved the nation.

He was fifty-six years old when he died. His life had been spent in thinking and doing for others, and the whole world mourned that such a life was ended.

Write about Abraham Lincoln, making a paragraph about each of the following topics:

His home in Kentucky.

His boyhood.

Lincoln as a man.

Why we honor Lincoln, and some ways in which we honor him.

And so he came.

From prairie cabin up to Capitol,

One fair ideal led our chieftain on.

-From "Lincoln, the Man of the People," by Edzin Markham. 


\section{Lesson ${ }_{102}$}

\section{BRICK}

In what respect is brick better than wood for building?

Tell what you know about the size and color of different kinds of brick. Describe the way in which they are made.

Mention the different purposes for which bricks are used.

How are the bricks in a wall held together?

Tell what the men who build brick houses are called, and name the tools they use. Which do you think is the stronger, brick or stone? Which is more commonly used? Tell why.

Bricks are dried in two ways. Those most commonly used are baked in an oven called a brick kiln. Some are dried in the sun.

The sun-dried bricks are called adobe. The Indians in some parts of our country make their houses of adobe.

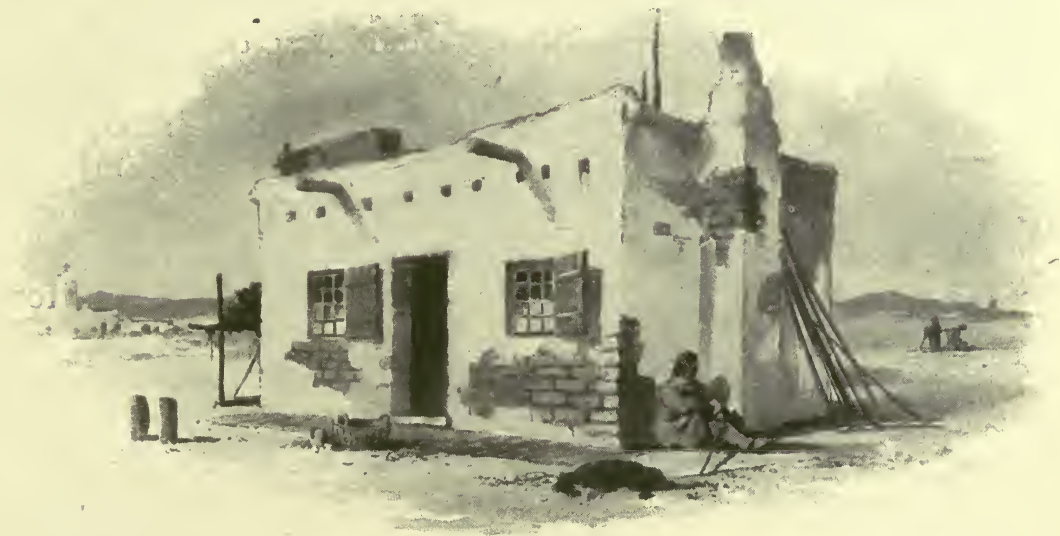

An adobe house 


\section{I6o Language Through Nature}

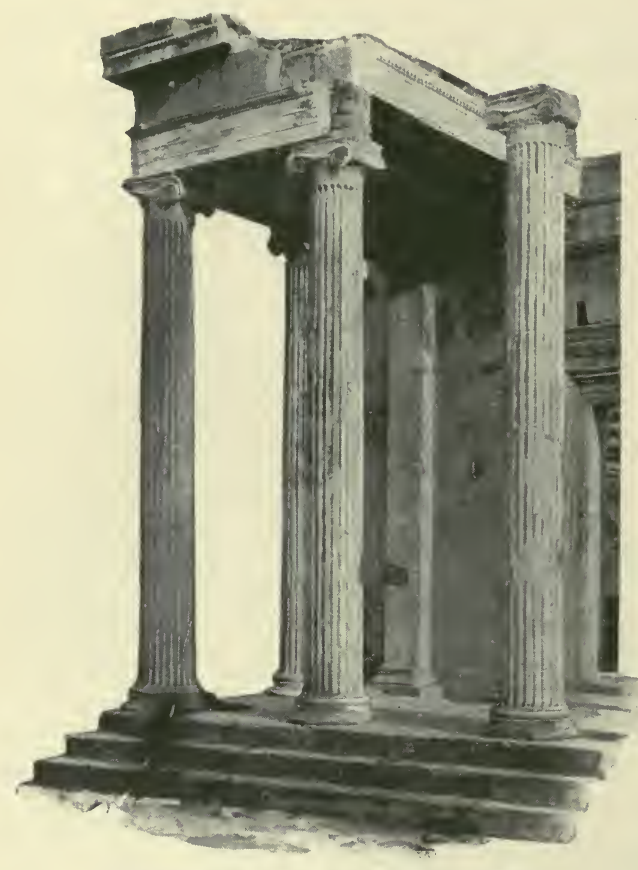

How stones were used by the Greeks

\section{Lesson 103 STONE}

Tell in what respects stone is a better material for building and paving than wood or brick.

What kinds of stone have you seen used for these purposes?

Tell why you think each kind was used.

How are stone buildings erected?

How are the blocks of stone held together?

Tell what the men are called who do this work, and name the tools used.

Tell what you know about the foundations and framework of stone buildings. How is stone used in place of wood in finishing the interior of any building? How are stone buildings often ornamented? Where on the building is ornament most often seen?

What qualities must stone have to be most suitable for this use?

Who does this work? Where is it done, and what tools are used?

Make a drawing of a design you would like to see cut in stone.

If you have clay, press a piece of it into a solid block and carve your design upon it. You may use sharpened sticks for tools. 


\section{Lesson 104}

\section{PREPARATION OF STONE FOR BUILDING}

Tell which kind of building stone is most used near your home. Why?

Where is building stone found?

Tell about the ways in which the stone is gotten out.

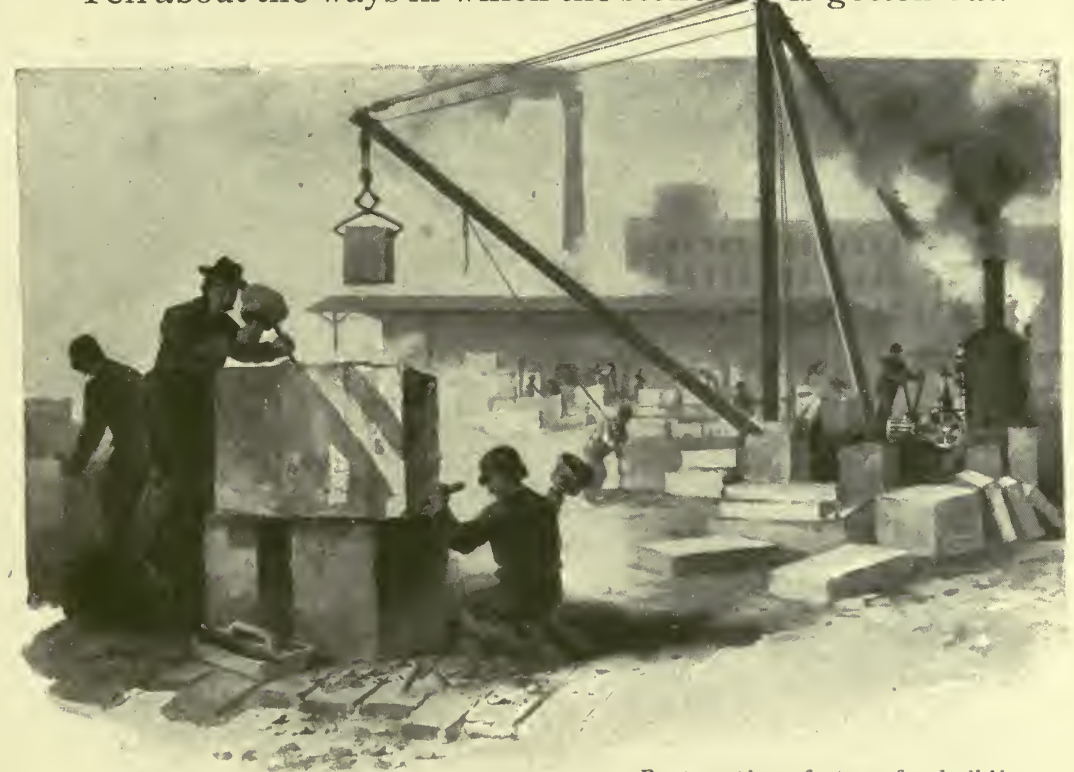

Preparation of stone for building

To what place is the stone first taken, and what is done to it there? How is it carried?

Tell what you know about the way building stone is measured and about its value.

Write all you know about building materials. 


\section{I62 Language Through Nature}

\section{Lesson 105 \\ A PICTURE STUDY}

What is this worker called?

With what is he working?

What shows that this boy is strong?

Tell what you think he is trying to make in the stone.

How does he know just where and how to cut the stone?

What tells you that this boy is being careful?

If you think he likes this work, tell why.

Mention any fine statue that you have seen which was made of stone. How does the sculptor work, and what does he use for a guide?

This is a picture of a marble statue made by the great sculptor, Michael Angelo.

\section{Lesson 106}

\section{MICHAEL ANGELO BUONARRO'TI}

QVER four hundred years ago, in a castle in a beautiful, sunny land, was born one of the greatest artists the world has known. The beautiful land was Italy. The castle was the home of a noble family named Buonarroti. The artist was a son of this family, and he was born in March, I475. His father named him Michael Angelo.

When the little boy was about a year old his 


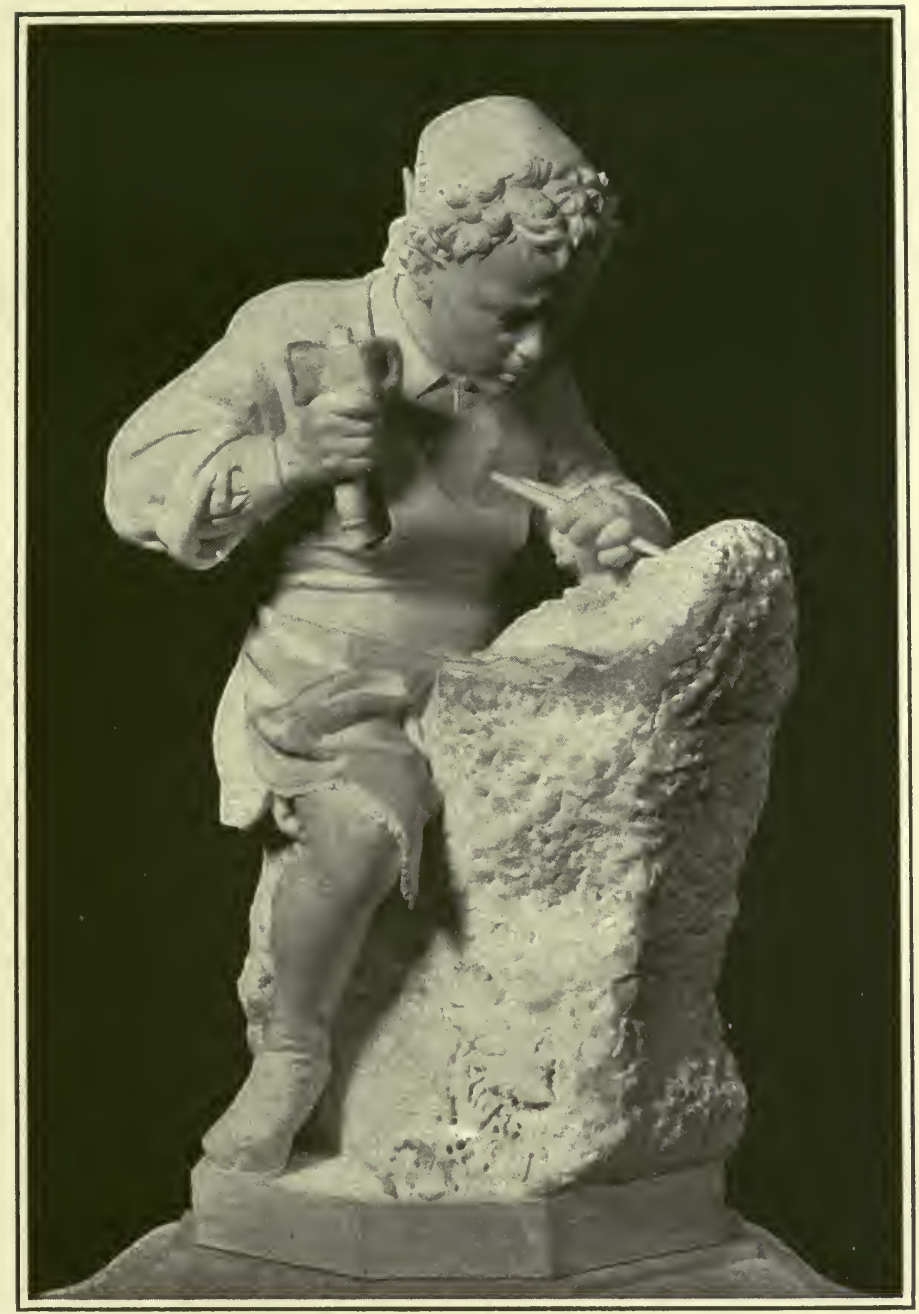

From a sculpcure by Micnuel Angelo Buonurroti THE YOUNG SCULPTOR 
father and mother had to go to the city of Florence, and he was left at the home of his nurse, who was the wife of a stonecutter. Here he breathed the pure mountain air, played in the sunshine, and grew sturdy and strong, as little boys should. He heard the ring of the stonecutter's hammer, watched the chips fly from under the chisel, and saw the rough blocks of stone grow into forms of beauty.

As soon as he could use his hands he began to draw pictures. He drew some on the white walls of his nurse's house, where they could be seen for many years. After a time his father and mother took him to Florence and sent him to school. One of his schoolmates was the pupil of a great artist, and after school Michael Angelo often went with him to watch the artists at their work. He wished to be an artist himself, and was very unhappy because his father and his uncles wished him to do something else. They did not know that he would some day paint beautiful pictures, make splendid buildings and fine statues that people would look at and enjoy for hundreds of years. However, they at last gave their consent, and he began to study drawing and painting. He learned rapidly, and soon undertook to model and to work in marble. 
At a place called Carrara, in Italy, there are quarries of very beautiful white marble. Michael Angelo often visited these quarries and selected the blocks of stone which he wished to use for his finest work.

When he was busy making a statue he struck swift, fierce blows. He seemed to know just what he wanted, and was sure and fearless.

The statue of "The Young Sculptor" is supposed to represent Michael Angelo himself at his much-loved work.

He lived to be eighty-nine years old, and through all his long life he was doing some great work. If you cannot journey to Italy to see the things he did, the fine dome of St. Peter's Cathedral, the wonderful paintings on the ceiling of the Sistine Chapel, or the great statue of David, you may see pictures of them all and read stories of their wonder and beauty.

Tell the story of this great artist's life in your own words.

Trifles make perfection,

But perfection is no trifle.

- Michael Angelo. 


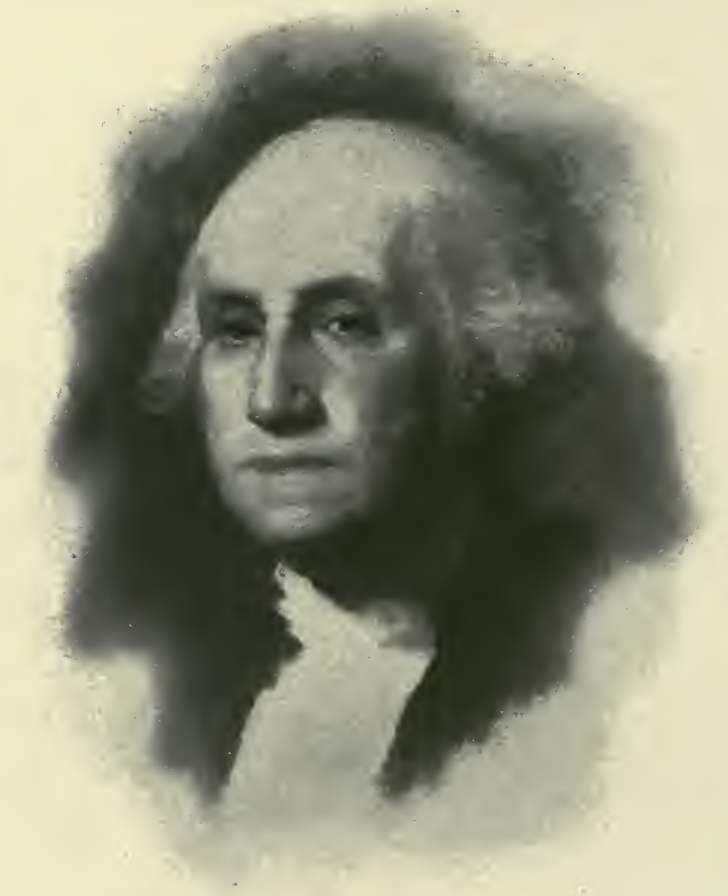

From an unfinished portrait, painted by Gilbert Stuart GEORGE WASHINGTON

\section{Lesson IO7 \\ GEORGE WASHINGTON}

Tell any story that you know about Washington. What kind of boy was he? What kind of man was he?

When does Washington's birthday occur, and why do we celebrate it?

Write the story about. Washington which you like best. 


\section{Lesson I08}

\section{RED RIDING HOOD}

O the wide lawn the snow lay deep,

Ridged o'er with many a drifted heap;

The wind that through the pine-trees sung

The naked elm-boughs tossed and swung;

While, through the window, frosty-starred,

Against the sunset purple barred,

We saw the somber crow flap by,

The hawk's gray fleck along the sky,

The crested biue-jay flitting swift,

The squirrel poising on the drift,

Erect, alert, his broad gray tail

Set to the north wind like a sail.

It came to pass, our little lass,

With flattened face against the glass,

And eyes in which the tender dew

Of pity shone, stood gazing through

The narrow space her rosy lips

Had melted from the frost's eclipse:

"Oh, see," she cried, "the poor blue-jays!

What is it that the black crow says?

The squirrel lifts his little legs 
Because he has no hands, and begs;

He's asking for my nuts, I know:

May I not feed them on the snow?"

Half lost within her boots, her head Warm-sheltered in her hood of red, Her plaid skirt close about her drawn, She floundered down the wintry lawn; Now struggling through the misty veil Blown round her by the shrieking gale;

Now sinking in a drift so low

Her' scarlet hood could scarcely show Its dash of color on the snow.

She dropped for bird and beast forlorn Her little store of nuts and corn, And thus her timid guests be-spoke: "Come, squirrel, from your hollow oak,-

Come, black old crow,-

Come, poor blue-jay,

Before your supper's blown away!

Don't be afraid, we all are good;

And I'm mamma's Red Riding Hood!"

O Thou whose care is over all, Who heedest even the sparrow's fall, 
Keep in the little maiden's breast

The pity which is now its guest!

Let not her cultured years make less

The childhood charm of tenderness,

But let her feel as well as know,

Nor harder with her polish grow!

Unmoved by sentimental grief

That wails along some printed leaf,

But prompt with kindly word and deed

To own the claims of all who need,

Let the grown woman's self make good

The promise of Red Riding Hood!

-John G. Whittier.

Write the contractions used in this poem. Tell what each means.

In what words do you find the apostrophe and $\mathrm{s}$ used to show possession?

Find the divided quotation in this poem.

To whom is Red Riding Hood speaking in each case of direct address? What mark separates the name of the one addressed from the rest of the sentence?

Describe in your own words the landscape as it appeared when this poem was written.

What animals were seen, and what was each doing?

Tell what the little girl thought, and what she asked to do.

Describe her appearance as she crossed the lawn.

What did she do?

What was the promise which this little girl's womanhood was to make good? 


\section{I7o Language Through Nature}

\section{Lesson. Iog}

\section{A THRIFTY BLUE JAY}

THE general belief among country people that 1 the jay hoards up nuts for winter use has probably some foundation in fact, though one is at a loss to know where he could place his stores so that they would not be pilfered by the mice and the squirrels. An old hunter told me he had seen jays secreting beechnuts in a knot-hole in a tree. * * A lady writing to me from Iowa says: "I must tell you what I saw a blue jay do last winter. Flying down to the ground in front of the house he put something in the dead grass, drawing the grass over it, first on one side, then on the other, tramped it down just exactly as a squirrel would, then walked around the spot, examining it to see if it was satisfactory. After he had flown away I went out to see what he had hidden; it was a nicely shucked peanut that he had laid up for a time of scarcity." Since then I have myself made similar observations. I have several times seen jays carry off chestnuts and hide them here and there upon the ground. They put only one in a place and covered it up with grass or leaves. Instead, therefore, 
of hoarding up nuts for future use, when the jay carries them off he is really planting them. When the snows come these nuts are lost to him, even if he remembered the hundreds of places where he had dropped them. May not this fact account, in a measure, for the oak and chestnut trees that spring up where a pine forest has been cleared from the ground?

-From "Signs and Se'asons," by John Burroughs.

- What is said in this selection about the way in which the blue jay stores food? What sometimes happens to the nuts which they hide?

Describe the appearance of any bird you have seen here during the winter, and tell what you know about its habits.

\section{Lesson i io}

\section{HENRY WADSWORTH LONGFELLOW}

WHEN Henry W. Longfellow was a boy he spent many happy days on his grandfather's farm. In the long winter evenings it was one of his greatest pleasures to sit before the great oldfashioned fireplace and listen to the wonderful tales of Indian life which his grandfather told.

Years went by and the boy became a man. $\mathrm{He}$ heard and read many interesting things. He traveled in strange lands far from the old farmhouse, 
172 Language Through Nature

but the stories his grandfather had told were never forgotten, and one day he gave them to the world in that most wonderful story of Indian life, the legend of Hiawatha.

For many years Mr. Longfellow's home was in Cambridge, Mass. While living there he wrote many poems and made many friends. He always loved children, and they in return admired and loved him. As Mr. Longfellow's seventy-second birthday drew near, the school children of Cambridge wished to give him some present that would show their love for him.

The "spreading chestnut tree," of which Mr. Longfellow speaks in one of his poems, grew near the poet's boyhood home. This tree had been cut down, but the wood had been carefully laid away. Of this wood a handsome armchair was made, a loving message was carved, upon it, and the chair was presented to Mr. Longfellow on his birthday, February 27, i879. Mr. Longfellow was greatly pleased with the children's gift, and thanked them for it in a charming poem called "From My Armchair." When the children came to see him each child was given a copy of the poem and was allowed to sit in the beautiful chair. 


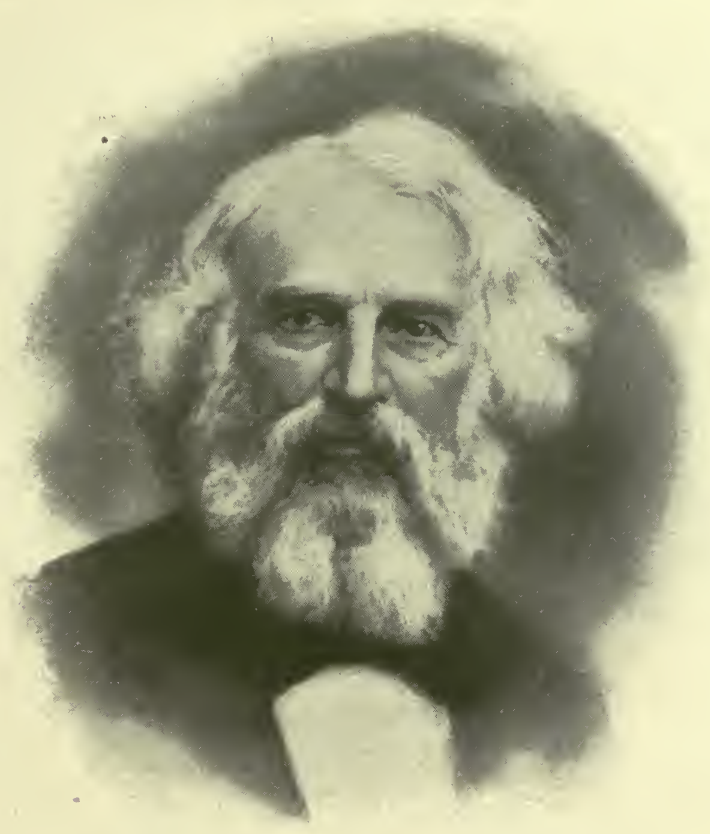

HENRY WADSWORTH LONGFELLOW

Of what people did Longfellow's grandfather tell him? In which poem does Longfellow tell us about these people? In which does he tell of the "spreading chestnut tree"?

Tell about the armchair which the children gave him, and why they gave it. How did the poet thank the children?

\section{Lesson I I I \\ MONTHLY SUMMARY}

Prepare your monthly summary for February.

Make pictures to illustrate the holidays or birthdays you have celebrated this month. Tell which one you enjoyed most, and why. 


\section{4 \\ Language Through Nature}

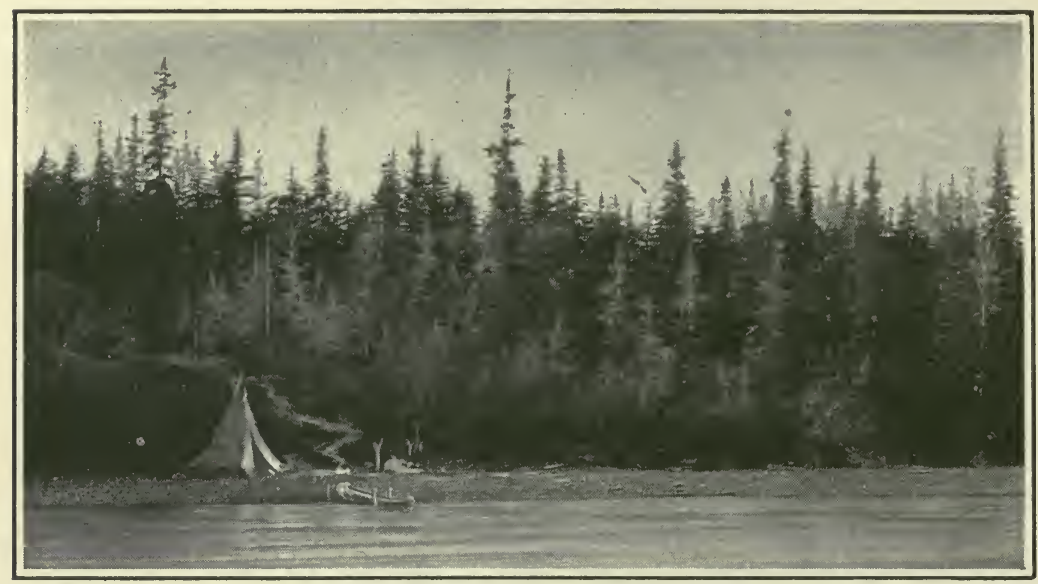

"Dark behind it rose the forest"

\section{Lesson I I 2}

\section{HIAWATHA'S HOME}

BY the shores of Gitche Gumee,

By the shining Big-Sea-Water,

Stood the wigwam of Nokomis,

Daughter of the Moon, Nokomis.

Dark behind it rose the forest,

Rose the black and gloomy pine-trees,

Rose the firs with cones upon them;

Bright before it beat the water,

Beat the clean and sunny water,

Beat the shining Big-Sea-Water. 
There the wrinkled old Nokomis

Nursed the little Hiawatha,

Rocked him in his linden cradle,

Bedded soft in moss and rushes,

Safely bound with reindeer sinews;

Stilled his fretful wail by saying,

"Hush! the Naked Bear will hear thee!"

* * * * *

-From "Hiawatha," by Henry W. Longfellow

Of whose home is this a description?

Of what was it made?

During what seasons would you like such a home?

Tell in what ways your house is better than a wigwam.

Of what is your house made?

Mention other $\mid$ materials of which houses are made. Tell which you $\sqrt{ }$ / think are best, and why.

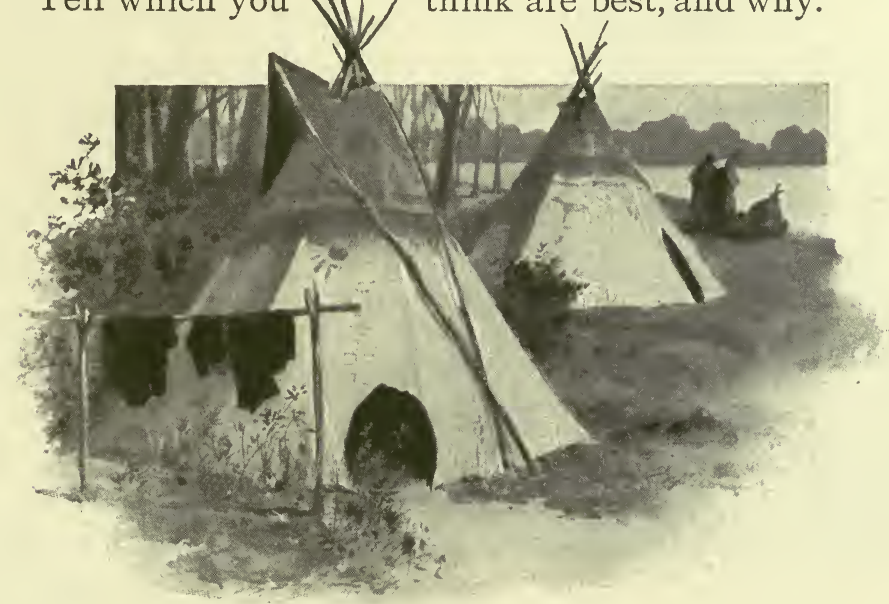

"The wigwam of Nokomis" 


\section{Lesson I I 3 \\ WOODS AND THEIR USES}

Mention some of the trees from which we get much of the wood used in building.

Tell what you know about the wood we get from each tree.

In building a house, where are strong, heavy timbers needed?

What kind of wood may be used for clap-boards, laths, and shingles?

What do you know about the ways of measuring wood, and the value of the different kinds?

In what places are woods that are beautiful in color and grain used?

Tell what you know about the value of these woods, and about the places from which they come.

Mention articles for which wood that bends is needed.

Tell of any places in a house where you think very hard wood would be of most service.

Mention places besides houses in which wood of great

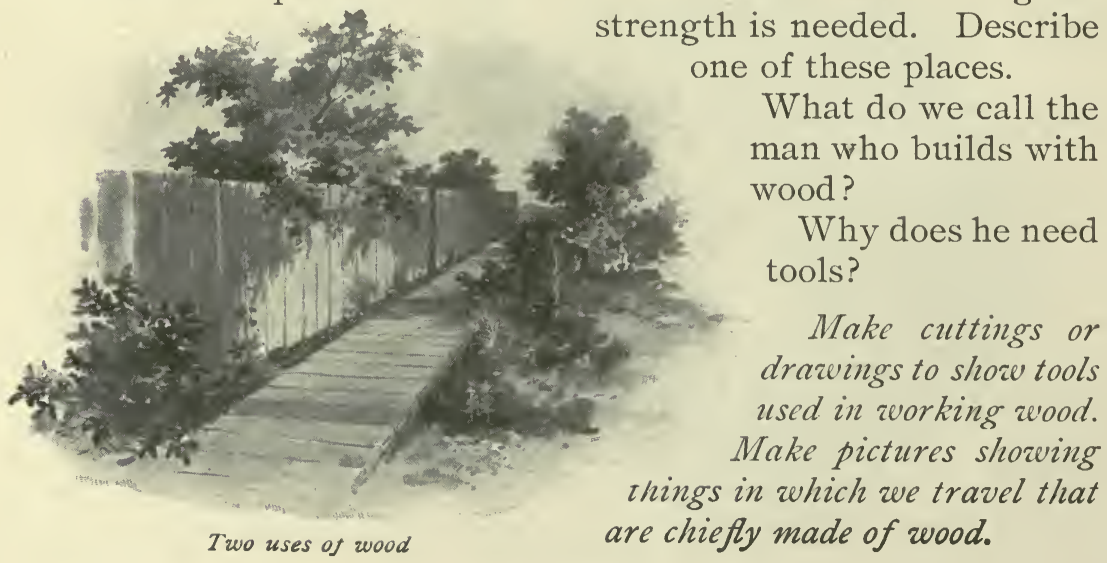




\section{Lesson I I 4}

\section{PREPARATION OF WOOD FOR USE}

Tell what you know about lumber woods and the work done there.

How are $\log$ s carried from the forest to the mills? Into what are the logs changed?

Tell about ways in which lumber is carried from the mills to the lumber yards.

Name as many as you can of the workers who helped get the lumber for your desk or chair.

Tell about any part of this work of which you know.

In the picture on the next page, find all the ways in which wood is used.

Make a picture showing one of the ways in which lumber is carried by water.

\section{SUGGESTED WORK}

Secure blocks of different kinds of wood and try to drive nails into each. What do you find out about their hardness?

Take strips or splints of different woods of equal length and size. Support a strip at each end and hang a weight in the center. Test each strip in the same way and tell which remain straight and which bend or break.

Collect specimens of different kinds of wood. Smooth and polish one surface of each specimen to show the grain. If possible, get a picture of the kind of tree from which each wood comes, a cross section of a branch, a leaf, and a specimen of the bark.

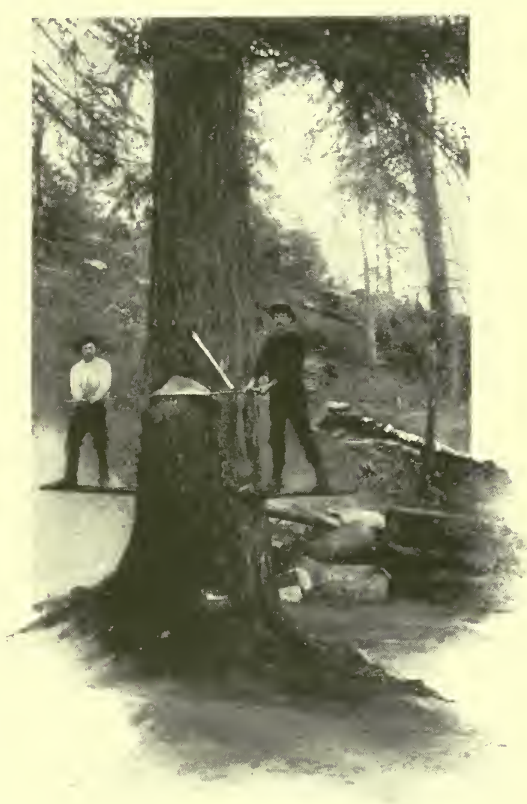

The work done in the woods 


\section{I78 Language Through Nature}

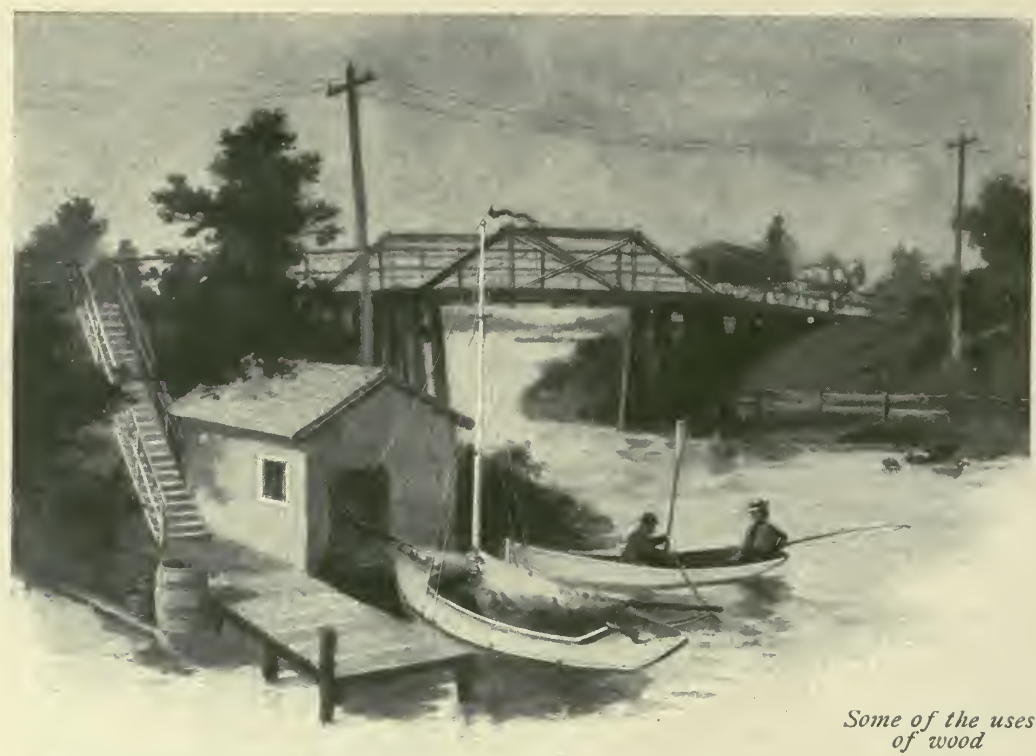

Mount all the specimens from one tree on cardboard and write a paper to put with them, telling their uses and value, and any other interesting facts about them that you may know.

Ч E who plants a tree,

1 He plants love;

Tents of coolness spreading out above Wayfarers, he may not live to see.

Gifts that grow are best, Hands that bless are blest.

Plant! Life does the rest.

Heaven and earth help him who plants a tree, And his work its own reward shall be. 


\section{Lesson I I 5 \\ VENTILATION}

How is the air in this room heated?

Place a thermometer near the floor. Tie another to the end of a window pole and put it near the ceiling.

What does each thermometer tell about the heat?

In what direction does the heated air seem to move?

Where do you think fresh air comes in?

Tell about all the ways you know for ventilating rooms.

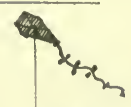

SUGGESTED WORK

Fan yourself with a piece of stiff paper or cardboard. Tell what you feel.

Place some bits of paper or feathers on the desk. Fan them, but do not touch them. What causes them to move? What is the moving power called?

Breathe into a glass containing lime water. Tell what change takes place in the appearance of the water. This is because the air we breathe into the water is not pure. It is not good for us to breathe the same air over and over, so the air in our rooms should be changed often. Where should an opening be made to let the foul air out of the room?

\section{Lesson i i 6 \\ THE WIND'S WORK}

Mention things that you have seen moved by the wind.

What work is done by the windmills?

How does the wind sometimes help people to travel?

What happens when a high wind blows over a body of water?

What do these things tell about the wind's strength?

Make pictures or cuttings of things that tell you the direction from which the wind is blowing. 
I saw the different things you did,

But always you yourself you hid.

I felt you push, I heard you call,

I could not see yourself at all -

$\mathrm{O}$ wind, a-blowing all day long,

$\mathrm{O}$ wind, that sings so loud a song!

-From "The Wind," by Robert Louis Stevenson.

\section{Lesson I I 7}

\section{THE FOOLISH WEATHER-VANE}

T $\mathrm{N}$ a little town by the sea, a shining weather1 vane was once put on the top of a high steeple to tell the direction of the wind. If it pointed west, the fishermen went fearlessly to sea, for they were quite sure the weather would be fine and their work safe. But if it pointed east, the men kept near the shore or staid at home and mended their nets, for when the east wind blew it was sure to bring a storm and it was not safe upon the sea.

For a long time all went well and the weathervane turned just as the wind told it to. But at last he noticed that the people looked up at him every morning before going to their work and, though he had done nothing but give them the wind's message, he began to feel very important. Soon the wind 
came by and whispered, "Point west, point west; tell that a fair day is at hand." But the weather-vane had by this time grown quite stiff with pride and refused to turn. "The people look $\mathbf{N}$ to me and do as I say; why should I follow your directions?" he said.

That morning when the fishermen looked at the weather-vane they were puzzled. "This wind seems like a west wind," said they, "but our weathervane points east. We will stay on land to-day." So they staid at home, and all day long the sky was cloudless and the sea still. Boats from other towns were seen sailing before a west wind, and the people knew that something was wrong with their weather-vane. But the weather-vane was now sure that the people followed him, and all night he swung about at will, to show what he could do.

The next morning as the wind rushed by it urged, "Point east! point east! a great storm is coming." But

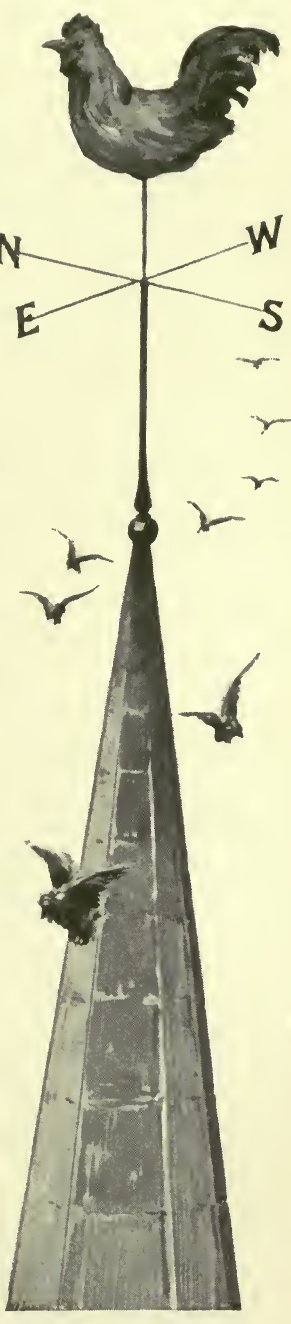

"A shining weathervane on the top of a 
the weather-vane paid no attention to the wind and pointed west. On this morning, though the weathervane told the fishermen to go to sea, they said, "This wind feels like an east wind," and looking about them they took the wind's message from trees and clouds, and nearly everyone staid at home.

Soon the sky grew black, the wind roared, and big waves dashed against the shore. The little boats that had gone out were dashed in pieces, and the men in them were saved only by the hard work of their friends on shore.

The foolish weather-vane was sorry to see the people in trouble, and wished he had done as he was told. He said, "Hereafter I will obey the wind," but it was too late, for the people said, "That weather-vane no longer tells the direction of the wind; we must put up a new one."

Tell in your own words the story of the foolish weather-vane. 


\section{Lesson I 8}

We are told in Longfellow's "Hiawatha" that long ago the Indians had an enemy - the Great Bear of the mountains - of whom they were much afraid. He was the terror of the nations, and was called Mishe-Mowka. A brave warrior named Mudjekeewis at last found and killed this terrible creature, and the following lines from "Hiawatha" tell how he was rewarded.

\section{THE FOUR WINDS}

"ЧONOR be to Mudjekeewis!

1 Henceforth he shall be the West-Wind,

And hereafter and forever

Shall he hold supreme dominion

Over all the winds of heaven.

Call him no more Mudjekeewis,

Call him Kabeyun, the West-Wind!"

Thus was Mudjekeewis chosen

Father of the Winds of Heaven.

For himself he kept the West-Wind,

Gave the others to his children;

Unto Wabun gave the East-Wind,

Gave the South to Shawondasee,

And the North-Wind, wild and cruel,

To the fierce Kabibonokka.

Young and beautiful was Wabun;

He it was who brought the morning;

He it was whose silver arrows 
Chased the dark o'er hill and valley; He it was whose cheeks were painted With the brightest streaks of crimson, And whose voice awoke the village, Called the deer, and called the hunter.

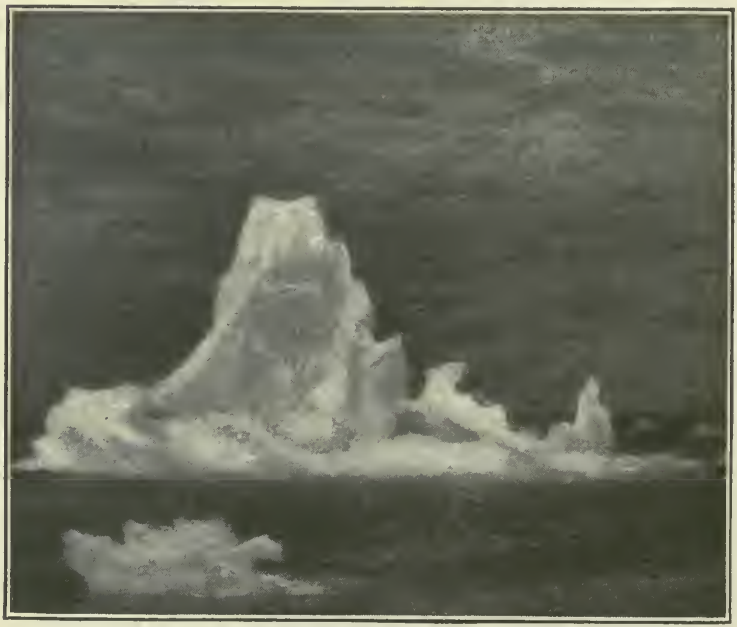

"The fierce Kabibonokka had his dwellings among icebergs"

\section{But the fierce Kabibonokka}

Had his dwelling among icebergs, In the everlasting snow-drifts, In the kingdom of Wabasso, In the land of the White Rabbit. He it was whose hand in Autumn Painted all the trees with scarlet, 
Stained the leaves with red and yellow ;

He it was who sent the snow-flakes,

Sifting, hissing through the forest,

Froze the ponds, the lakes, the rivers,

Drove the loon and sea-gull southward,

Drove the cormorant and curlew

To their nests of sedge and sea-tang

In the realms of Shawondasee.

Shawondasee, fat and lazy,

Had his dwelling far to southward,

In the drowsy, dreamy sunshine,

In the never-ending summer.

He it was who sent the wood-birds,

Sent the robin, the Opechee,

Sent the bluebird, the Owaissa,

Sent the Shawshaw, sent the swallow,

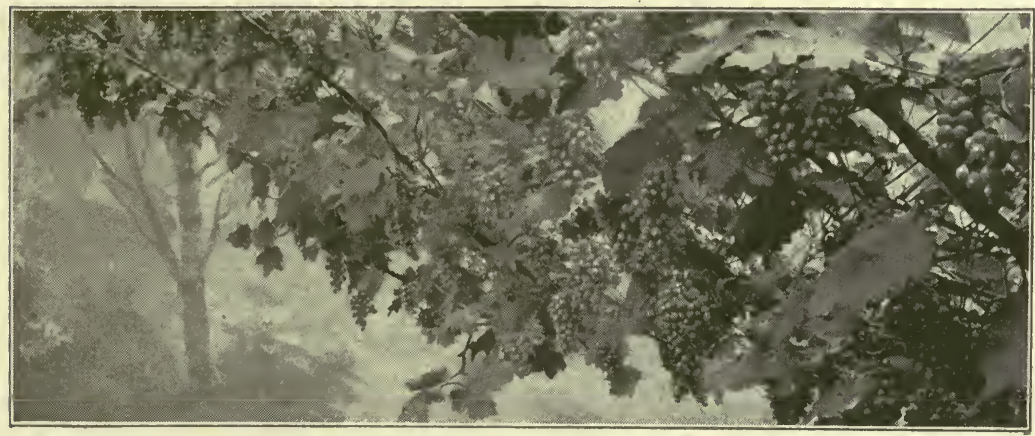

"And the grapes in purple clusters" 
Sent the wild-goose, Wawa, northward,

Sent the melons and tobacco,

And the grapes in purple clusters.

*

* * * *

-From "Hiawatha," by Henry W. Longfellow.

Write in your own words a description of Wabun, Kabibonokka, and Shawondasee.

Write a separate paragraph about each of the winds mentioned in the poem, and tell what each was said to bring.

If you write any of the compound words in this selection, be careful to use the hyphen.

\section{Lesson I I 9 \\ THE WEATHER}

Look over your monthly papers on the weather and tell which wind blew most frequently during the fall months.

From what direction did it most often come when it was raining? Which wind blew most often during the winter?

Tell what you have noticed about each wind.

What changes do your weather records show in regard to temperature; frost and dew ; rain or snow?

Tell of any changes you have noticed out of doors in plant or animal life. What reasons can you give for these changes?

March is merry, March is mad,

March is gay, March is sad;

Every humor we may know

If we list the winds that blow.

-Frank Dempster Sherman. 


\section{Lesson I 20 \\ THE SUN AND THE WIND}

GREAT dispute once arose between the wind $A$ and the sun. Each claimed to be the stronger and for some time they were unable to settle the matter. At last a traveler was seen coming along the road and they agreed that the one who could first get him to take off his cloak should be called master.

The wind had the first trial, and blew over land and sea with all his might. The waters were lashed into foam and great waves tossed the ships to and fro; the air was full of flying dust and leaves, and trees bowed or broke before his strength. Through it all he tugged and pulled at the man's cloak, but try as he would the traveler only bent lower and drew his cloak more closely about him.

Then the sun's turn came. At first the man failed to notice his gentle beams, but he soon unfastened his cloak and then threw it far back. At last he pulled it entirely off, and wiping his heated forehead threw himself down to rest, saying, "How strong the sun is to-day!" 
The wind had nothing more to say, and though he still likes to show his strength, he knows that the silent sun can conquer, while he storms in vain.

Tell the story of the sun and the wind in your own words.

Great is the sun and wide he goes Through empty heaven without repose; And in the blue and glowing days More thick than rain he showers his rays.

-From "Summer Sun," by Robert Louis Stevenson.

\section{Lesson I 2 I}

\section{A PICTURE STUDY}

Tell what you see in this picture.

What seems to be the most prominent object in it?

How has the artist made it appear so prominent?

Tell what you see in the distance.

What can you say of the land? The sky? The water?

Describe the windmill.

Tell how you think people could get to this mill.

Describe the house at the left of the mill?

If you think anyone lives in this house, tell why.

What in the picture tells you of the season?

Of what country do you think this picture tells?

What do you like best in this picture?

Write a description of this picture. 


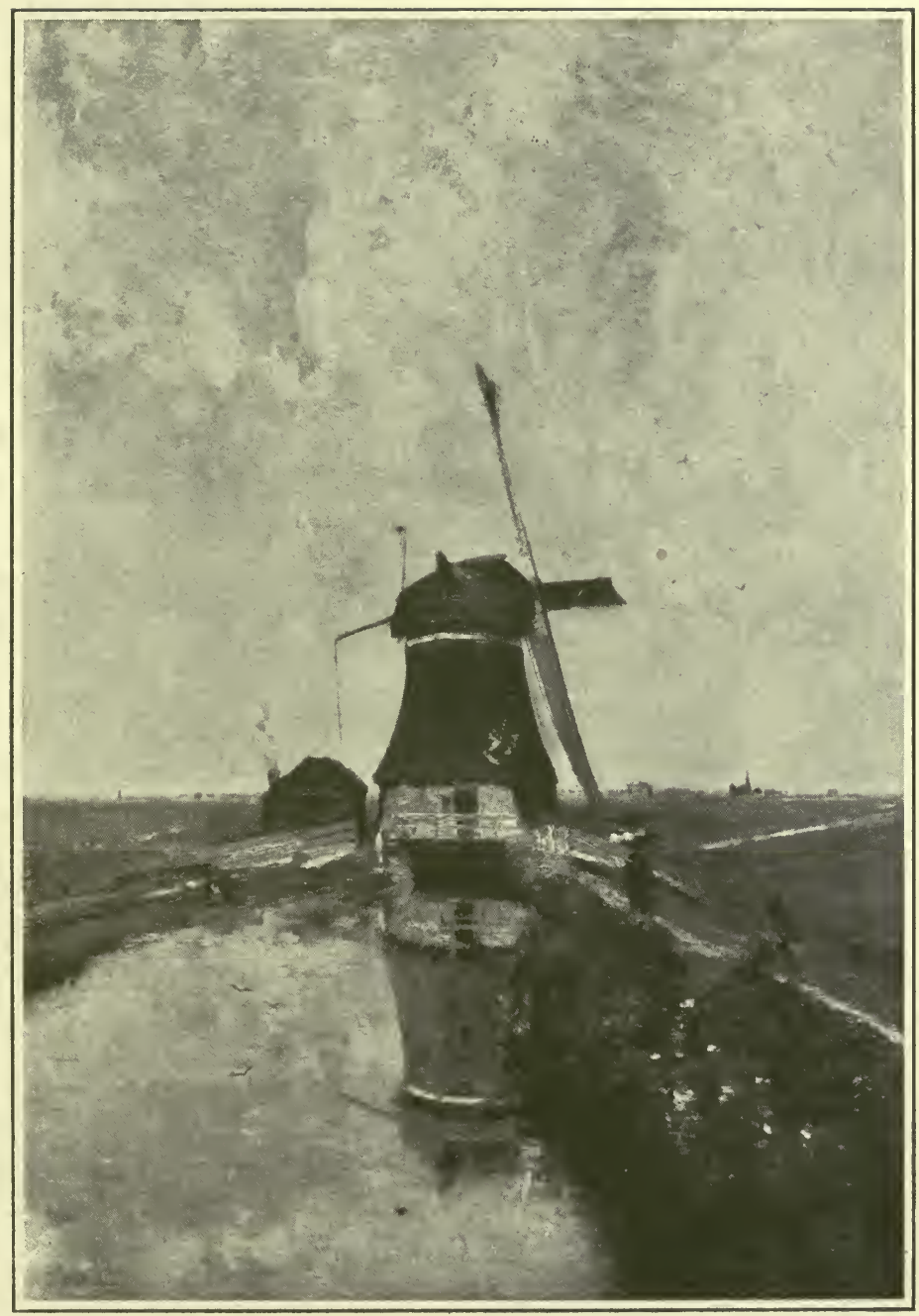

After a painting by P.J. C. Gabriel

THE WINDMILL 


\section{Lesson $\quad 22$}

\section{PAUL JOSEPH CONSTANTINE GABRIEL}

$A^{M O N G}$ the many painters whose pictures have A helped to make the world more beautiful are the artists of the little country of Holland. Some of these artists lived and worked centuries ago. They are dead, but their works remain, and their names are not forgotten.

Others are living at the present time, and are noted for the truth and beauty of their pictures.

One of these artists of to-day is Paul Joseph Constantine Gabriel, who painted the picture called "The Windmill." This artist lives in Holland. His home is a most interesting place. The walls of his studio, hall, and stairway are completely covered with beautiful pictures, the work of his own pencil and brush. They are all pictures of brave little Holland, such as Dutch artists lore to paint.

In these pictures one sees dark fields with canals gleaming like silver threads between them. One sees old windmills standing like giants with outstretched arms, and great expanses of sky through which one can almost hear the sweeping of strong, 
wild winds. Such are the pictures which Gabriel delights to paint.

We are told that this artist is quite deaf, but, while he is shut off from the enjoyment of sweet sounds, he is doubly quick to recognize the beauty which is everywhere for those who have eyes to see.

Tell what you can of this artist and his work.

of what other Dutch artist have you read?

\section{Lesson $\quad$ I 23}

\section{A LAUGHING CHORUS}

O , such a commotion under the ground When March called, "Ho, there! ho!" Such spreading of rootlets far and wide, Such whispering to and fro.

And, "Are you ready?" the Snowdrop asked,

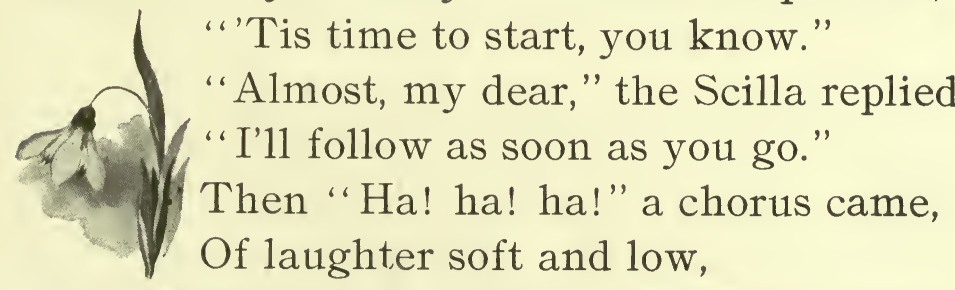

From the millions of flowers under the groundYes-millions-beginning to grow. 


\section{Language Through Nature}

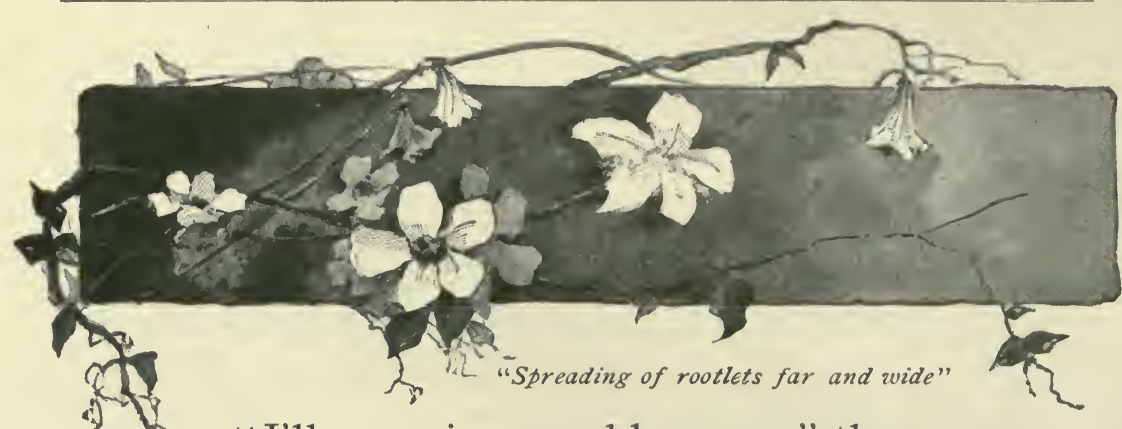

"I'11 promise my blossoms," the Crocus said,

"When I hear the bluebirds sing."

And straight thereafter, Narcissus cried, " My silver and gold I'll bring."

"And ere they are dulled," another spoke, "The Hyacinth bells shall ring,"

And the Violet only murmered, "I'm here, And sweet grew the air of spring.

Then, "Ha! ha! ha!" a chorus came,

Of laughter soft and low,

- From the millions of flowers under the groundYes-millions - beginning to grow.

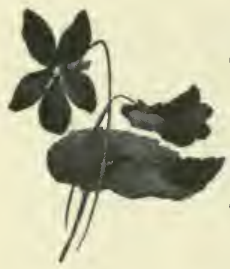

Oh, the pretty, brave things! through the coldest days,

Imprisoned in walls of brown,

They never lost heart though the blast shrieked loud,

And the sleet and the hail came down; 
But patiently each wrought her beautiful dress, Or fashioned her beautiful crown;

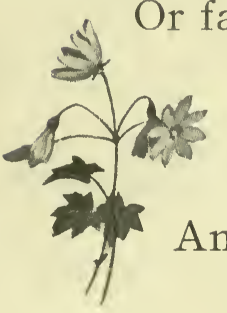
And now they are coming to brighten the world,

Still shadowed by winter's frown;

In a chorus soft and low,

The millions of flowers hid under the ground Yes - millions - beginning to grow.

With what exclamation did March call the flowers?

Tell in your own words what happened under the ground when the flowers heard this call.

Mention the flowers that helped to make the chorus.

Quote the words in which each one told what he would give to help make the spring beantiful.

Which of these quotations are divided?

Why is the Narcissus said to bring "silver and gold"?

What had the flowers been doing underground during the cold weather? Why are they called "brave" and "patient"?

Tell how flowers brighten the world.

\section{Lesson I 24 MONTHLY SUMMARY}

Make a summary of your wcather records for the past month. Compare this with the weather summary for January. Tell of any effects of the changes in weather. 


\section{Lesson $\quad$ I 25 \\ WILD GEESE}

THE wind blows, the sun shines, the birds sing 1 loud,

The blue, blue sky is flecked with fleecy dappled cloud,

Over earth's rejoicing fields the children dance and sing,

And the frogs pipe in chorus, "It is spring! It is spring!"

The grass comes, the flower laughs where lately lay the snow,

O'er the breezy hill-top hoarsely calls the crow, By the flowing river the alder catkins swing, And the sweet song sparrow cries, "Spring! - It is spring!"

Hark, what a clamor goes winging through the sky!

Look, children! Listen to the sound so wild and high!

Like a peal of broken bells, - kling, klang, kling,Far and high the wild geese cry, "Spring! It is spring!" 
Bear the winter off with you, $O$ wild geese dear! Carry all the cold away, far away from here;

Chase the snow into the north, O strong of heart and wing,

While we share the robin's rapture, crying, "Spring!

It is spring!"

- Celia Thaxter.

Tell all you can about the spring day described in the first two stanzas of this poem. When do such days come?

What is there in such a day to cause a feeling of happiness?

When do such days come?

Quote the words which "the frogs pipe in chorus."

Words used in such a manner are called exclamations, and are each followed by a mark (!) called the exclamation point.

Find the other exclamations used in this poem.

What is the cry of the wild geese said to be like?

Tell why the geese were asked to carry the winter off with them. To what place were they asked to carry it, and why?

Give a reason for calling these birds "strong of heart and wing."

Learn this poem.

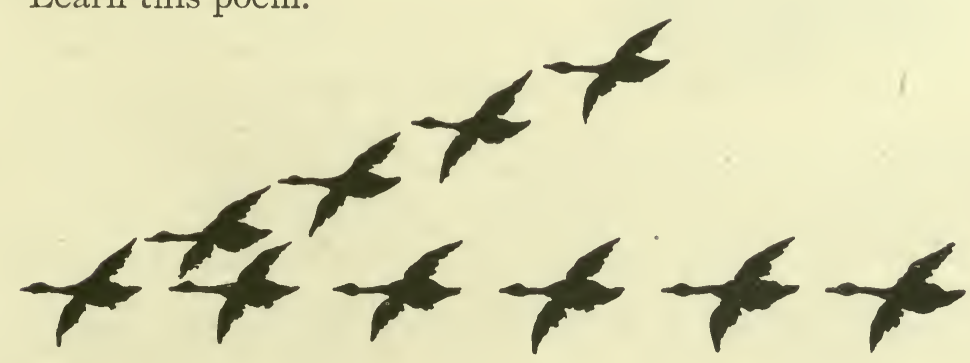




\section{I96 Language Through Nature}

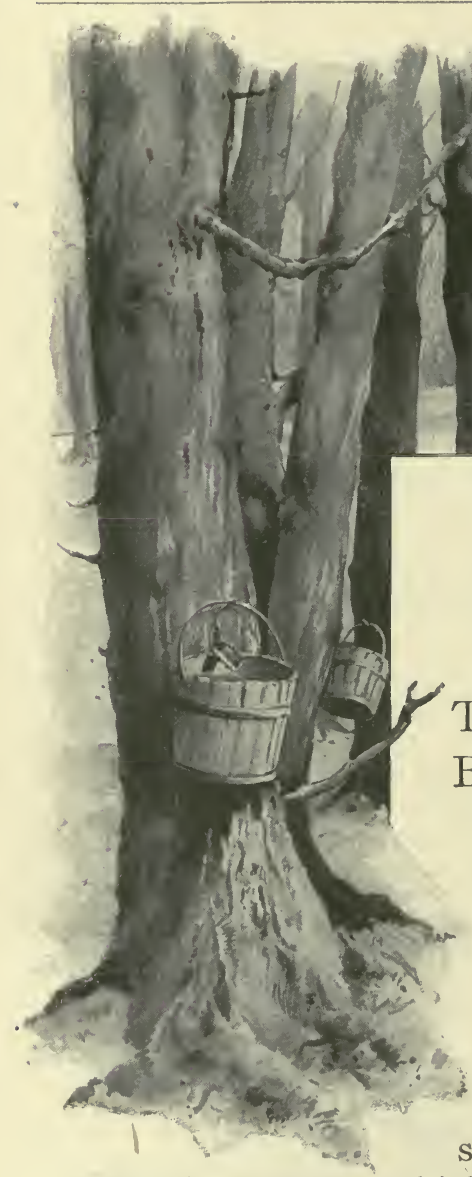

The woods are still sleeping,

But grass is a-peeping

From under the snow.

The swallows are coming,

The bees are a-humming,

The sap has begun to flow!

- Andrea Hofer.

At what season of the year does sap begin to flow?

Mention ways in which the sap of trees is used by man.

Tell which of these uses seem most important.

Tell all you know about the making of maple sugar.

In what ways is the sap of other trees prepared for use?

Write about the ways in which the following parts of trees are used-wood, bark, fruit, leaves, sap. Arrange in paragraplis. 


\section{Lesson I 27}

\section{BUDS}

Describe the appearance of trees and bushes in winter.

Tell how they look in the spring.

From what do the leaves and blossoms come?

Tell all you can of the color, size, and shape of buds.

Tell what you notice about the arrangement of the buds on the twigs. When were they formed upon the trees and bushes?

How were the buds protected during the cold weather?

What causes the leaves and blossoms to appear?

\section{SUGGESTED WORK}

Bring twigs to school from as many varieties of trees as possible. Make paint-

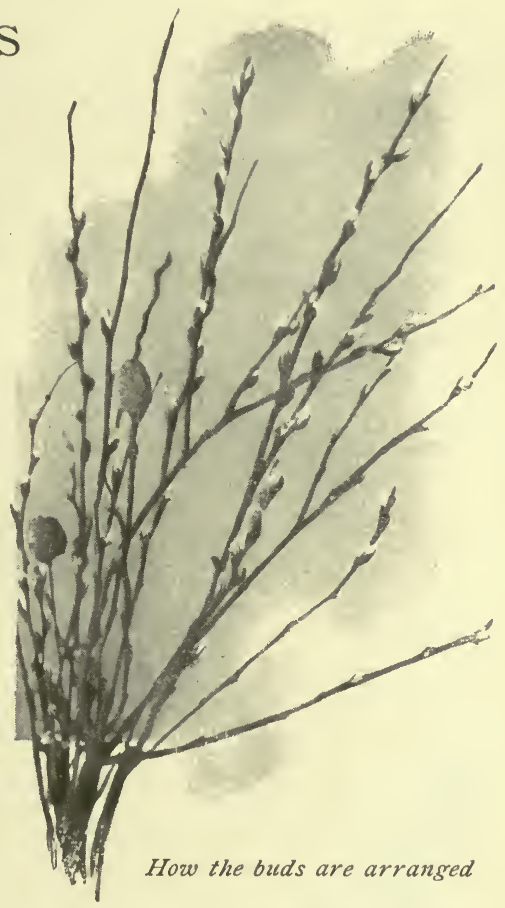
ings or drawings of one twig of each kind. Place the twigs in water and watch to see what happens.

After a week make another painting or drawing of the same twig, showing what changes have taken place.

Watch the trees from which the twigs came to see if a similar change takes place there. Keep a record of the date on which each kind of tree blossoms. Watch for any visitors that may come to the tree. Try to find why they come.

Write a paper to put with your drawings, giving anything of interest about the tree that you have not been able to tell in your picture of it.

If you have in your collection of woods a leaf, a specimen of the bark, and a cross section from the same kind of tree, add the twig, and your paper upon the tree to that collection. 


\section{Lesson I 28}

\section{THE TREE}

THE Tree's early leaf-buds were bursting their 1 brown;

"Shall I take them away?" said the Frost, sweeping down.

"No, leave them alone

Till the blossoms have grown,"

Prayed the Tree, while he trembled from rootlet to crown.

The Tree bore his blossoms, and all the birds sung: "Shall I take them away?" said the Wind, as he swung.

"No, leave them alone

Till the berries have grown,"

Said the Tree, while his leaflets quivering hung.

The Tree bore his fruit in the midsummer glow:

Said the girl, "May I gather thy berries now?"

"Yes, all thou canst see:

Take them; all are for thee,"

Said the Tree, while he bent down his laden boughs low. 
Of what time in the tree's life does the first stanza tell?

What question did the frost ask the tree?

Quote the tree's reply.

Why did the tree tremble?

Tell what the wind asked when the tree bore her blossoms.

Quote the tree's answer.

Tell when the girl came to the tree, and for what she asked.

What reply did the tree make?

Tell why you think the tree was ready to give the ripe fruit to the girl.

Make pictures to illustrate each stanza.

\section{Lesson I 29}

\section{SPRING FLOWERS}

Mention any flowers that you have seen in bloom this spring.

Tell which one you like best, and why. Describe its dress, and tell where it grows.

Which flowers bring us "gold" as does the Narcissus?

Name the colors that you have seen in spring flowers.

Which flowers have sweet odors?

Tell which flowers you think the bees like to visit.

Mention things that help flowers grow.

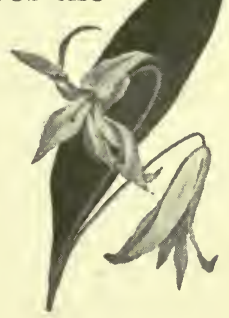

Everywhere about us are they glowing, Some like stars, to tell us Spring is born. -From "Flowers," by Henry W. Longfellow. 


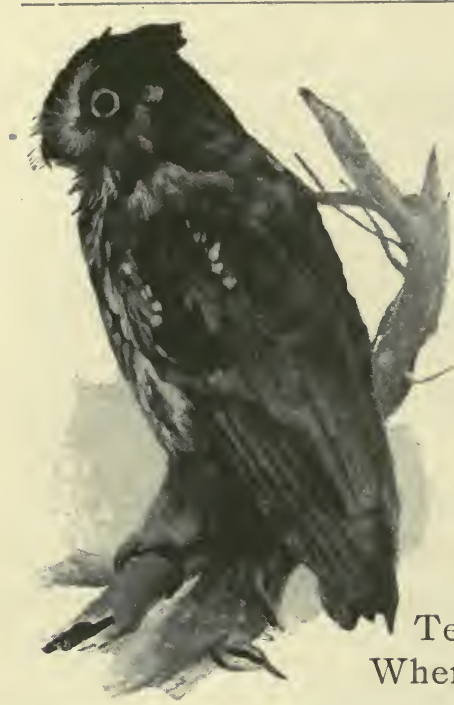

Where does the owl nest?

\section{Lesson I 30 BIRDS}

Tell where many of the birds have been during the winter.

Mention birds that have returned this spring, and the order in which you saw them.

Describe any one of these birds. Tell what you can of its flight or other movements. What can you say of its call or song?

Tell what you know about its food.

Write about one of these birds, telling why it went away last fall, where it went, what you think it saw while away, its return journey, and why it came back.

\section{SUGGESTED WORK}

Watch for birds returning from the South. Note the color and size of each. Watch the way in which they fly. Listen for their call or song. Find out what they eat, and how they get their food. Learn each bird's name.

Watch for any signs of nest-building. What material does the bird gather? Where does it build? What means does it take for the protection or concealment of its nest? Keep a record of the date on which you first see each bird.

Beloved of children, bards and spring,

O birds, your perfect virtues bring,

Your song, your forms, your rhythmic flight,

Your manners for the heart's delight,

Nestle in hedge, or barn, or roof,

Here weave your chamber weather-proof.

-From "May Day," by Ralph Waldo Emerson. 


\section{Lesson I 3 I \\ THE LESSON IN NEST- BUILDING}

ONCE upon a time there was a great meeting of birds. There were gathered together a thrush, blackbird, lark, robin, bluebird, wren, swallow, sparrow, owl,-and also many more. The magpie had found a way to build a wonderful nest, and the other birds wished to
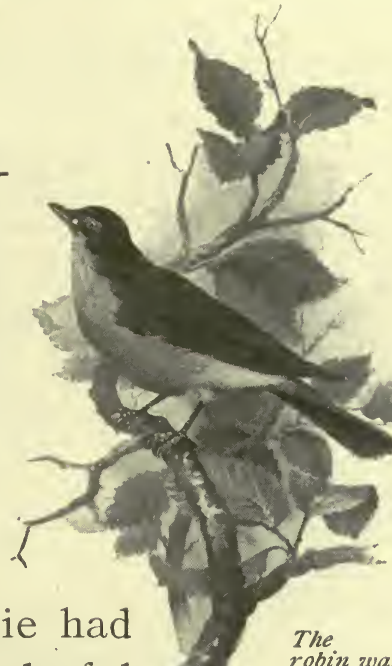
know how it was done. So she called them all together to show them.

After telling them to watch carefully, she began to build by taking some mud and pressing it into a round, flat shape. Before she had time to do more one of the birds flew away, thinking she had learned all there was to know about nestbuilding, and to this day her children build their nests with mud, for they have been taught no better way.

Next the magpie took bits of twigs and pressed them into the mud for a strong foundation. With- 


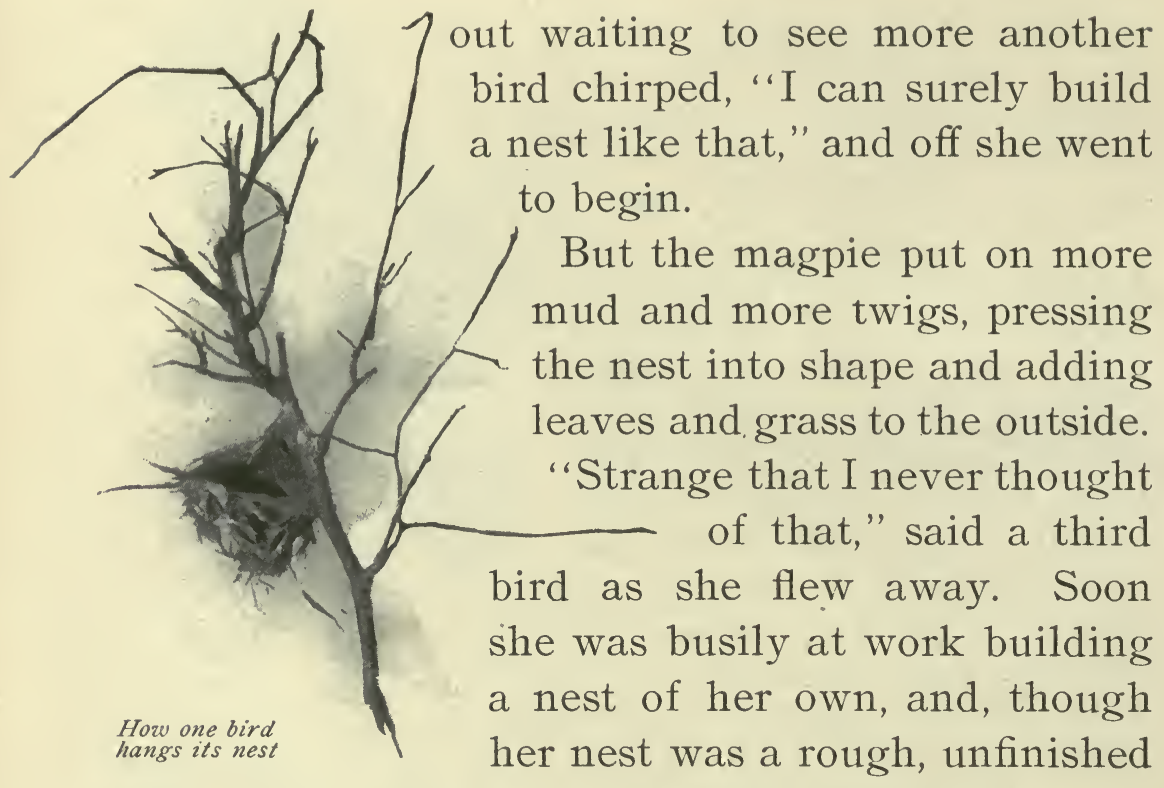
affair, many others are still made just like it.

The magpie worked away, weaving in thread or hair to make the nest strong, and lining it with straw and soft feathers until it was fine indeed.

Only a few birds had enough patience to stay for the whole lesson. Long before it was finished most of them had flown away to build nests for themselves. Each had noticed only a part of the building, and so made their separate nests in many different ways. But every bird thought it knew all about nest-building, and so never took another 
lesson. This is why there are so many different kinds of nests built to-day.

Tell about the lesson in nest-building.

Which part of the magpie's lesson do you think was learned by some bird that you have seen?

Make pictures showing places where the birds which you know might build nests.

\section{Lesson I 32 \\ INSECT LIFE}

And there's never a leaf nor a blade too mean

To be some happy creature's palace.

-From "The Vision of Sir Launfal," by James Russell Lowell.

What insects have you noticed this spring?

Tell where you saw them, and what they were doing.

Could they be easily seen? If not, tell the reason.

Describe the movements of any of these insects.

What sounds have you heard them make, and how do you think they were made?

Tell what you can about the winter homes of any of these insects, how they were protected from the cold, and where they get food.

Tell ways in which some insects are of use to man.

Mention insects that depend upon plants for food.

Choose the insect that you know most about and write a paragraph on each of the following topics:

Its appearance. Its home. Its movements. Its food.

Tell abcut any way in which this insect is useful or injurious. Remember to use capital letters and punctuation marks correctly. 


\section{Language Through Nature}

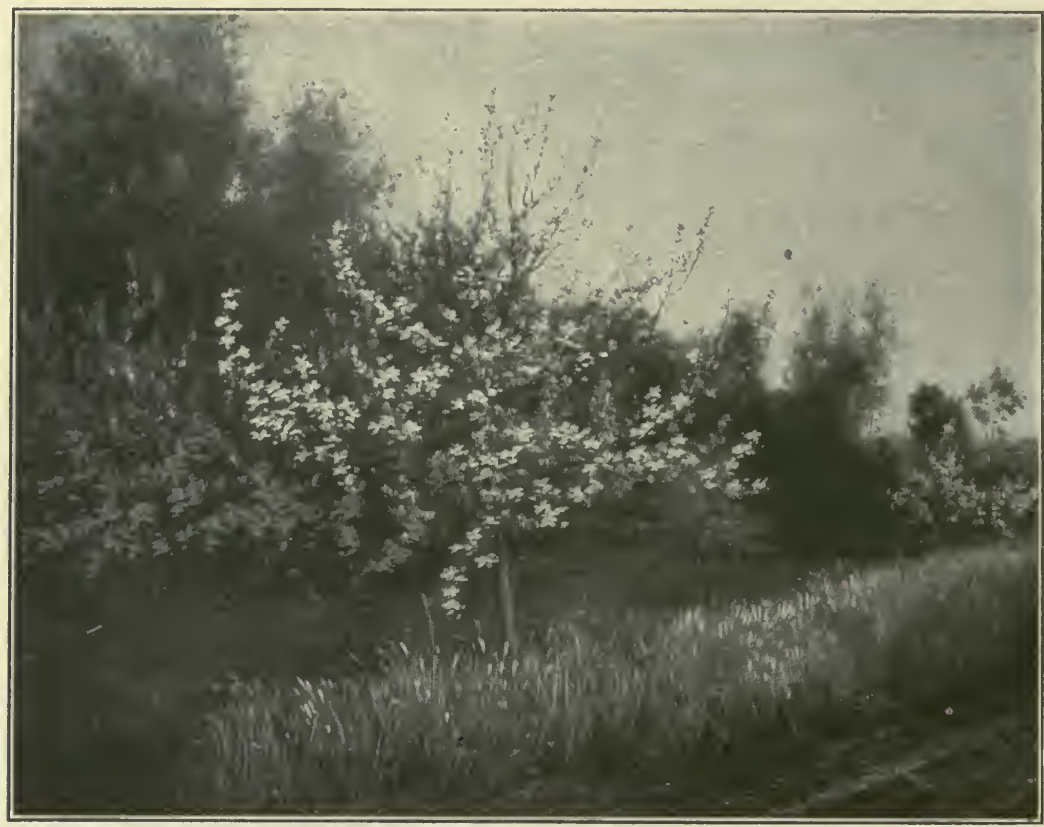

From a painting by Charles françois Daubigny SPRINGTIME

"The apple-blossom is very important to the bees"

\section{Lesson I 33}

\section{BEES}

THE honey-bee goes forth from the hive in 1 spring like the dove from Noah's ark, and it is not till after many days that she brings back the olive leaf, which in this case is a pellet of golden 
pollen upon each hip, usually obtained from the alder or swamp willow. In a country where maple sugar is made the bees get their first taste of sweet from the sap as it flows from the spiles, or as it dries and is condensed upon the sides of the buckets. They will sometimes, in their eagerness, come about the boiling place, and be overwhelmed by the steam and the smoke. But bees appear to be more eager "The honey-bee goess forth
from the hive in spring" for bread in the spring than for honey; their supply of this article, perhaps, does not keep as well as their stores of the

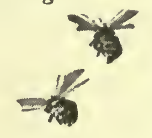
latter; hence fresh bread, in the shape of new pollen, is diligently sought for. My bees get their first supplies from the catkins of the willows. How quickly they find them out. If but one catkin,opens anywhere within range a bee is on hand that very hour to rifle it, and it is a most pleasing experience to stand near the hive some mild April day and see them come pouring in with their little baskets packed with the first fruitage of the spring. They will have new bread now; they have been to mill in 
good earnest; see their dusty coats, and the golden grist they brìng home with them.

When a bee brings pollen into the hive he advances to the cell in which it is to be deposited and kicks it off as one might his overalls or rubber boots, making one foot help the other; then he walks off without ever looking behind him; another bee, one of the indoor hands, comes along and rams it down with his head and packs it into the cell as the dairymaid packs butter into a firkin. * * * * *

The first honey is perhaps obtained from the flowers of the red maple and the golden willow. The latter sends forth a wild, delicious perfume. The sugar maple blooms a little later, and from its silken tassels a rich nectar is gathered. * * The apple-blossom is very important to the bees. A single swarm has been known to gain twenty pounds in weight during its continuance. Bees love the ripened fruit, too, and in August and September will suck themselves tipsy upon varieties like the sops-of-wine.

-From "Locusts and Wild Honey," by John Burroughs.

Tell in your own words what Mr. Burroughs says in this selection about bees. 


\section{Lesson 134 \\ BLOSSOMS A.ND BEES}

Mention any trees that you have noticed with blossoms.

Describe any of the blossoms that you have seen and tell which you like best. How do you sometimes know that a tree is in bloom before you see the flowers?

Tell what visitors come to the blossoms and what they gather from them. 'Tell all you can about the way in which these materials are gathered and carried.

. How do bees use what they get from flowers?

Describe the sound they make.

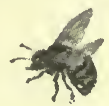

'Tell how they defend themselves when disturbed.

What use do people often make of the bees' store?

'Tell what you know about the ways in which people shelter and care for bees.

\section{Lesson I 35 \\ KING SOLOMON AND THE BEE}

I $\mathrm{N}$ olden times there lived a wise king named Solomon. He knew all the flowers of the field and the trees of the forest; the secrets of the birds and squirrels; all the insects and creeping things, where they lived and how they got their food. People who had disputes to settle took them to him, believing that he would know and tell them what was right, and so correct was he in his judgments 
that kings of distant lands came to his country or sent their great men to learn of him.

The Queen of Sheba heard of Solomon's fame and decided to visit him and test for herself his great wisdom. She had her most skillful workmen make a bunch of artificial flowers, and so perfect were they that the keenest eye could not tell them from the flowers that grow in the field. When she came before the king, these make-bèlieve flowers and a bunch of real flowers were brought in and the king was asked to tell which were the real flowers.

The king was puzzled, for, look as carefully as he might, his eye could not tell which flowers were real. Just then he caught sight of a bee outside the window and told a servant to throw wide the sash. The bee flew into the room and soon made its way to the heart of the real flowers. Then the king said, "The answer to your question is plain, O Queen; the strong and wise may learn from the smallest creature if he will but watch for its teaching."

The queen answered, "I have come far to learn the secret of your wisdom, O King, and my journey is not in vain. I begin to see that you are truly wise."

Write the story of King Solomon and the Bee. 


\section{Lesson I 36}

\section{SPRING WORK ON THE FARM}

Tell what work a farmer must be about in the spring-time. Why does he plow the fields?

What else is done to prepare the soil for the seed?

Tell which seeds the farmer will sow and which he will plant. Where do you think he will get his seed?

When the seeds begin to grow, how must they be cared for?

Some seeds are sown in the autumn. Te11 what happens to them during the winter.

Besides the sowing and the planting, describe some other spring work that the farmer must do, and tell why it is necessary.

Make drawings or cuttings illustrating some of the work which the farmer does in the spring; also some of the farm tools or machincs.

"We plow the fields and scatter the good seed o'er the land,

But it is fed and watered by God's almighty hand. He sends the snow in winter, the warmth to swell the grain,

'The breezes and the sunshine and sweet refreshing rain." for Children," by Eleanor Smith. 


\section{Lesson 137 \\ A PICTURE STUDY}

Tell what this man is doing, and how the ground has been prepared for the seed.

What in the picture shows you how and by whom this has been done?

How does the sower carry the seed, and how much does he sow at a time?

What can you say of the time it will take to sow the whole field? How do you think this man feels about his work?

What tells you that he is able to do it?

For what do you think he hopes as he sows the seed?

What does this picture tell you about the kind of worker this man is?

If he does his part and puts the seed into the ground, of what help is he sure?

Tell what you remember about the artist who painted the nicture of which this is a copy.

\section{THE PARABLE OF THE SOWER}

\section{$\mathrm{B}^{\mathrm{EHOLD}}$, a sower went forth to sow;}

B And when he sowed, some seeds fell by the wayside, and the fowls came and devoured them up: Some fell upon stony places, where they had not much earth: and forthwith they sprung up, because they had no deepness of earth:

And when the sun was up, they were scorched; and because they had no root, they withered away. 


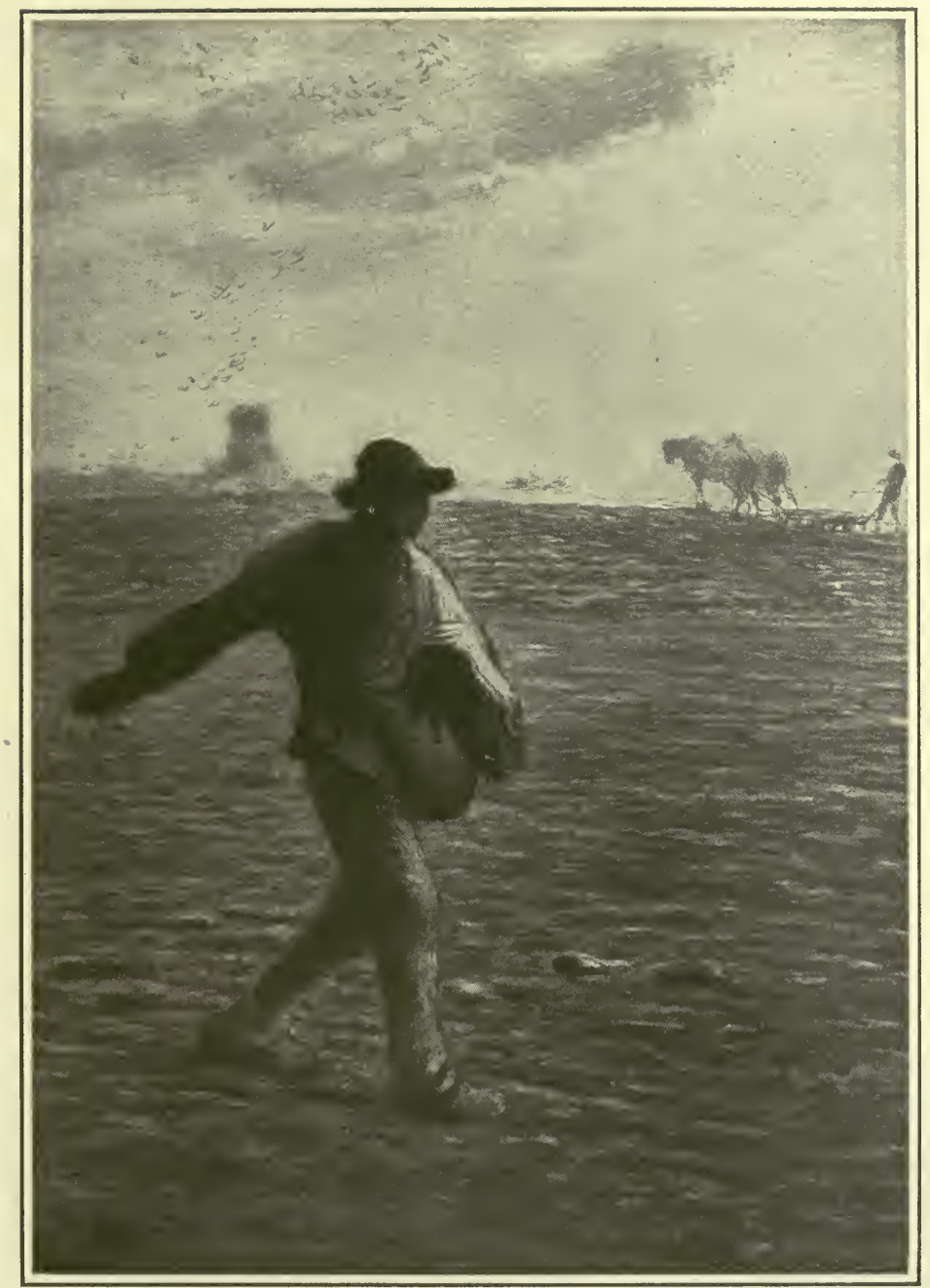

From a painting by Jean François Millet THE SOWER 
And some fell among thorns; and the thorns sprung up, and choked them:

But others fell into good ground, and brought forth fruit, some a hundredfold, some sixtyfold, some thirtyfold.

-The Bible: St. Matthew xiii, 3-8.

Find the meaning of the word parable. Tell this parable in your own words.

\section{Lesson I 38 SPRING}

What do your weather records show about the temperature and length of day at this time?

Tell about any changes that are being made about your house. What can you say about the heating and lighting of your home at this season?

What changes do people make in their clothing?

Tell about the goods which are displayed in shop windows at this time of the year.

What changes are made in the street cars?

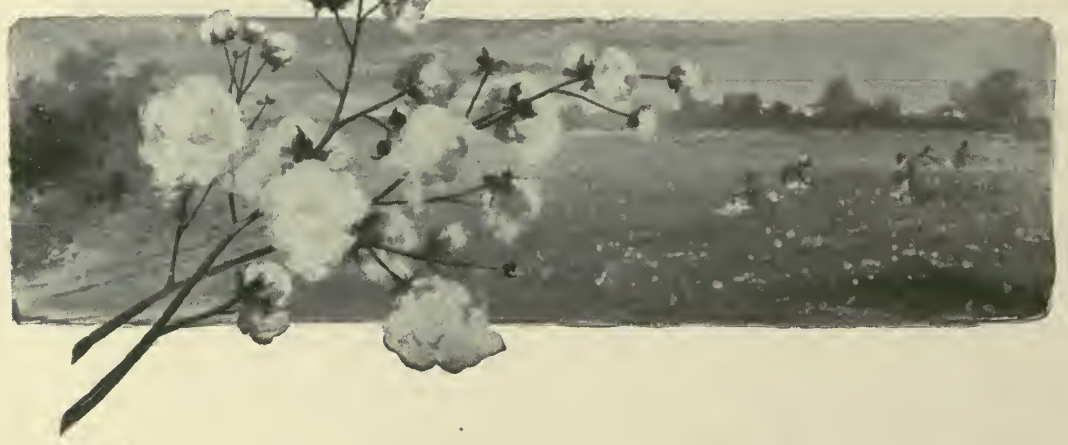




\section{Lesson I 39}

\section{COTTON}

Why is cotton cloth used for clothing in warm weather?

Describe the different forms

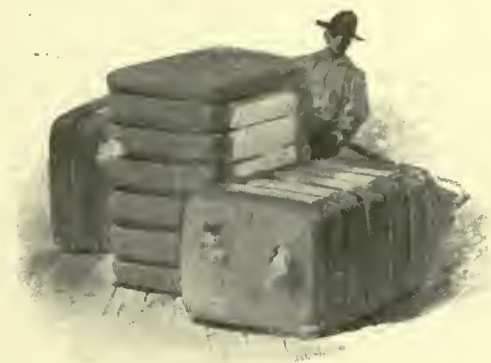
in which cotton is used.

From what is cotton obtained, and in what kind of climate does it grow? Tell all you can of the cultivation and picking of cotton, and how it is prepared for use.

Why are some kinds of cotton cloth thick and heavy, while others are light and thin?

Mention different kinds of cloth which are made of cotton.

Tell what you know about the different colors and designs which we see in cotton cloth.

From whom do we purchase this cloth? Where does he get it?

Make designs for a stripe, a check, and a flowered pattern which you would like to see made in cotton cloth.

\section{SUGGESTED WORK}

Soak some Lima beans, peas, and morning-glory seeds in water over night. From one of each kind remove the skin and carefully examine what you find.

Write a description of what you see, and tell the use of each part.

Lay a piece of white sheet-wadding on the top of a glass of water.

Scatter some flax seed on the wadding and notice what happens.

Fill a large glass jar with black soil. Plant some seeds, such as beans, peas, corn, and squash, in the soil, and quite close to the glass. Keep the jar on a sunny window-sill, wwatering the soil well, and notice how the different seeds behave. You may also plant beans, peas, corn, and other seeds, some in sand and some in damp sawdust.

Watch all these seeds, noticing when they begin to grow and how they grow.

Bring a small box of soil from your garden or yard in which you have put no seed. Place it in the sunshine and water it daily. Watch to see what grows in this soil. From what do these plants come and how did the seed get into the soil? 


\section{Lesson 140 SEEDS}

Mention some of the seeds that are being planted at this season. How do we get these seeds for planting?

If you bought any of them, tell where.

How were they put up and by whom was this work done? Why is it necessary for some one to save seeds in this way?

If you have examined a large seed name the parts you have found. Tell what you can of the use of each part. What is necessary for the growth of the seed?

Mention other things beside seeds from which plants grow. Name some of the plants that are so grown.

\section{Lesson I 4 I GARDENS}

Describe different kinds of gardens. If you have ever had a garden you may tell how the soil was prepared for the seed.

Name the seeds used in making the garden. Which were planted and which sown? In what month was this work done?

What plants did you set out, and how did you care for them?

Tell what you got from the garden when the plants and seeds had grown. For what were these things used?

Of what use are the flowers in your garden?

Some tools used in gardening 


\section{Lesson ${ }^{4} 4$ \\ THE STORY OF A SEED}

TWO seeds lay beside each other in the earth, 1 waiting. It was cold, and rather wearisome; and, to beguile the time, the one found means to speak to the other.

"What are you going to be?" said the one.

"I don't know," answered the other.

"For me," rejoined the first, "I mean to be a rose. There is nothing like a splendid rose. Everybody will love me then!"

"It's all right," whispered the second; and that was all he could say; for somehow when he had said that, he felt as if all the words in the world were used up. So they were silent again for a day or two.

"Olı, dear!" cried the first, "I have had some water. I never knew till it was inside me. I'm growing! I'm growing! good-by!"

"Good-by!" repeated the other, and lay still; and waited more than ever.

The first grew and grew, pushing itself straight up, till at last it felt that it was in the open air, for 
it could breathe. And what a delicious breath that was! It was rather cold, but so refreshing. The flower could see nothing, for it was not quite a flower yet, only a plant; and they never see till their eyes come, that is, till they open their blossoms, then they are flowers quite. So it grew and grew, and kept its head up very steadily, meaning to see the sky the first thing, and leave the earth quite behind as well as beneath it. But somehow or other, though why it could not tell, it felt very much inclined to cry. At length it opened its eyes. It was morning, and the sky was over its head; but alas! itself was no rose-only a tiny white flower. It felt yet more inclined to hang down its head and to cry; but it still resisted, and tried hard to open its eye wide, and to hold its head upright, and to look full at the sky.

"I will be a star of Bethlehem at least!" said the flower to itself.

But it had felt very heavy; and a cold wind rushed over it, and bowed it down towards the earth. And the flower saw that the time of the singing of birds was not come, that the snow covered the whole land, and that there was not a single flower in sight but itself. And it half-closed its leaves in terror and the dismay of loneliness. 
But at that instant it remembered what the other flower used to say; and it said to itself, "It's all right; I will be what I can." And thereon it yielded to the wind, drooped its head to the earth, and looked no more on the sky, but on the snow. And straightway the wind stopped, and the cold died away, and the snow sparkled like pearls and diamonds; and the flower knew that it was the holding of its head up that had hurt it so; for that its body came of the snow, and that its name was Snowdrop. And so it said once more, "It's all right!" and waited in perfect peace. All the rest it needed was to hang its head after its nature.

- From "David Elginbrod," by George Macdonald.

Write "The Story of a Seed" in your own words, being careful to make your work correct in form.

\section{Lesson I 43 \\ FARM ANIMALS}

Mention all of the animals you can which are usually seen at a farm.

Tell which help the farmer in his work and in what way they help him.

Why do you think the farmer keeps other animals that do not help him work? Mention some such animals, and tell in what way each one is useful. 


\section{I8 Language Through Nature}

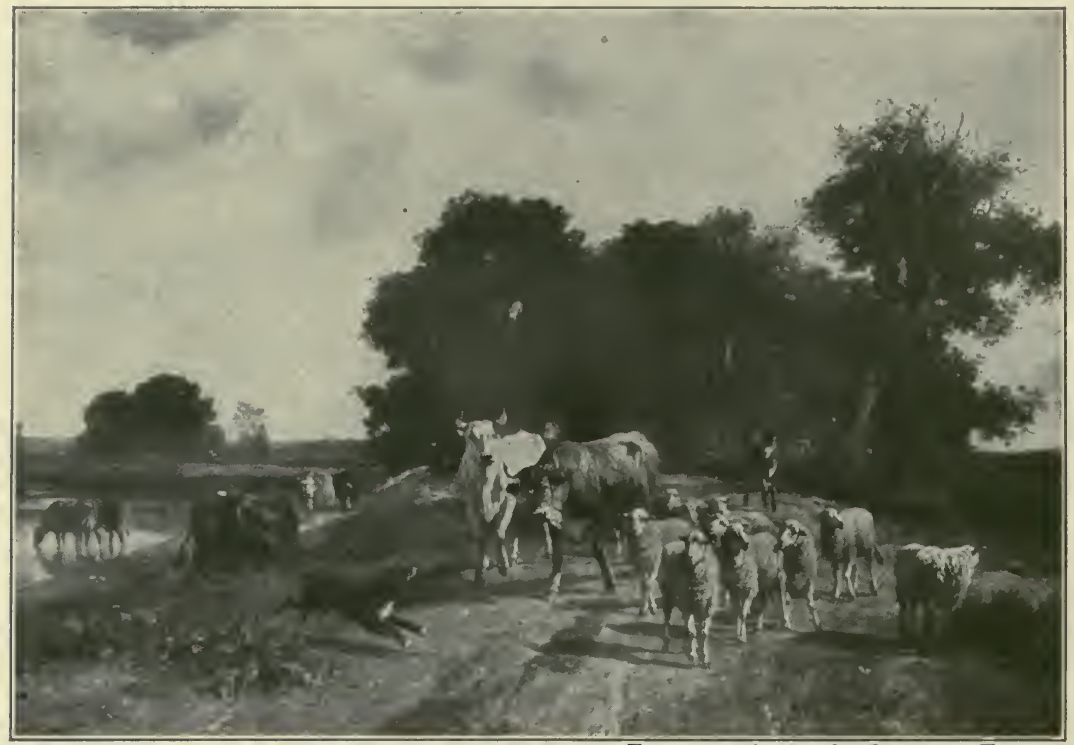

From a painting by Constant Troyon

FARM ANIMALS

Tell how the farm animals are sheltered and fed during the winter.

How are they cared for during the warm weather?

Write a paper telling what articles of food are obtained from the following:
Cows
Poultry
Pigs
Sheep

Tell from whom you obtain these articles of food, and from whom he gets them.

Be careful about paragraphing, punctuation, and use of capital letters. 


\section{Lesson I 44}

\section{FARM PRODUCTS}

Mention some of the products of the farm which are used on the table. Tell which of these are obtained from plants.

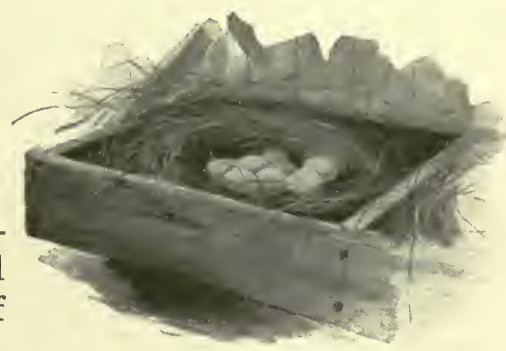

Mention those products which are obtained from animals.

How are they prepared for our use?

Of whom do we get these farm products?

Tell all you can of how they are brought from the farm.

How are these products measured and sold?

Make pictures showing ways in which these products are carried from place to place.

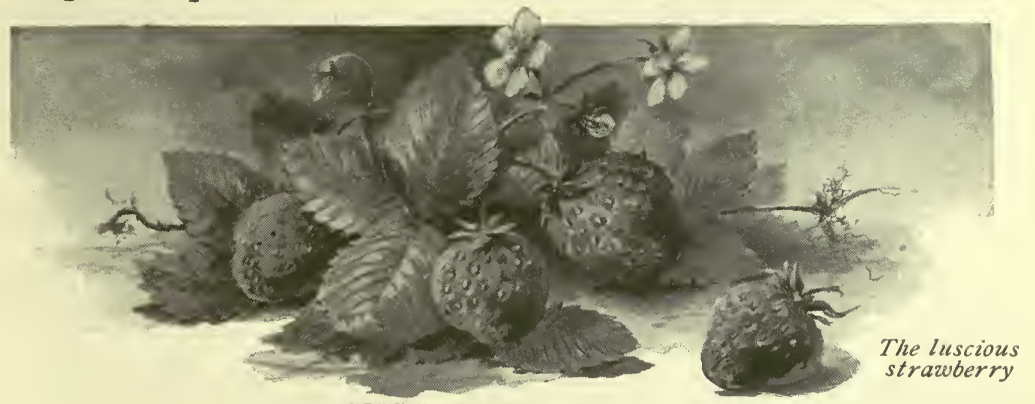

SUGGESTED WORK

If you would like to see how one of the farm products is prepared for use, you can easily do so in the following manner.

Get a quart jar to use as a churn. Make a dasher by nailing two short, flat sticks together in the form of an $\mathrm{X}$. Fasten this $\mathrm{X}$ at its center to the end of a stick a foot long. Make a cover of wood or of cardboard, with a hole in the middle, through which the stick or handle passes.

Put a pint of sour cream in the jar. Now churn until the butter comes. Gather up all the little yellow bits. Press them together. Wash with cold water and work in a little salt.

Write a description of your churning. 


\section{Lesson I 45}

\section{ROADS}

Mention any farm or garden products that are brought to our market in wagons.

What kind of roads are necessary to make this work safe and easy? How are roads made, and how are they mended or kept in good order?

Tell why the roads or streets are paved in cities.

Name materials which are used for this purpose.

Which material do you think is best, and why?

How are these materials used in paving?

\section{Lesson 146}

\section{A PICTURE STUDY}

Tell what you see in this picture.

What is the woman doing?

In what other picture in this book have you seen women resembling this one?

Where do you think this woman lived? Why do you think so?

What do you think of this woman as a worker?

What in the picture tells you this?

What else does the picture show you about the woman?

What do you think the artist intended to be the principal thing in this picture? Tell how he has shown this.

Who was the artist, and what other pictures by him have you seen? 


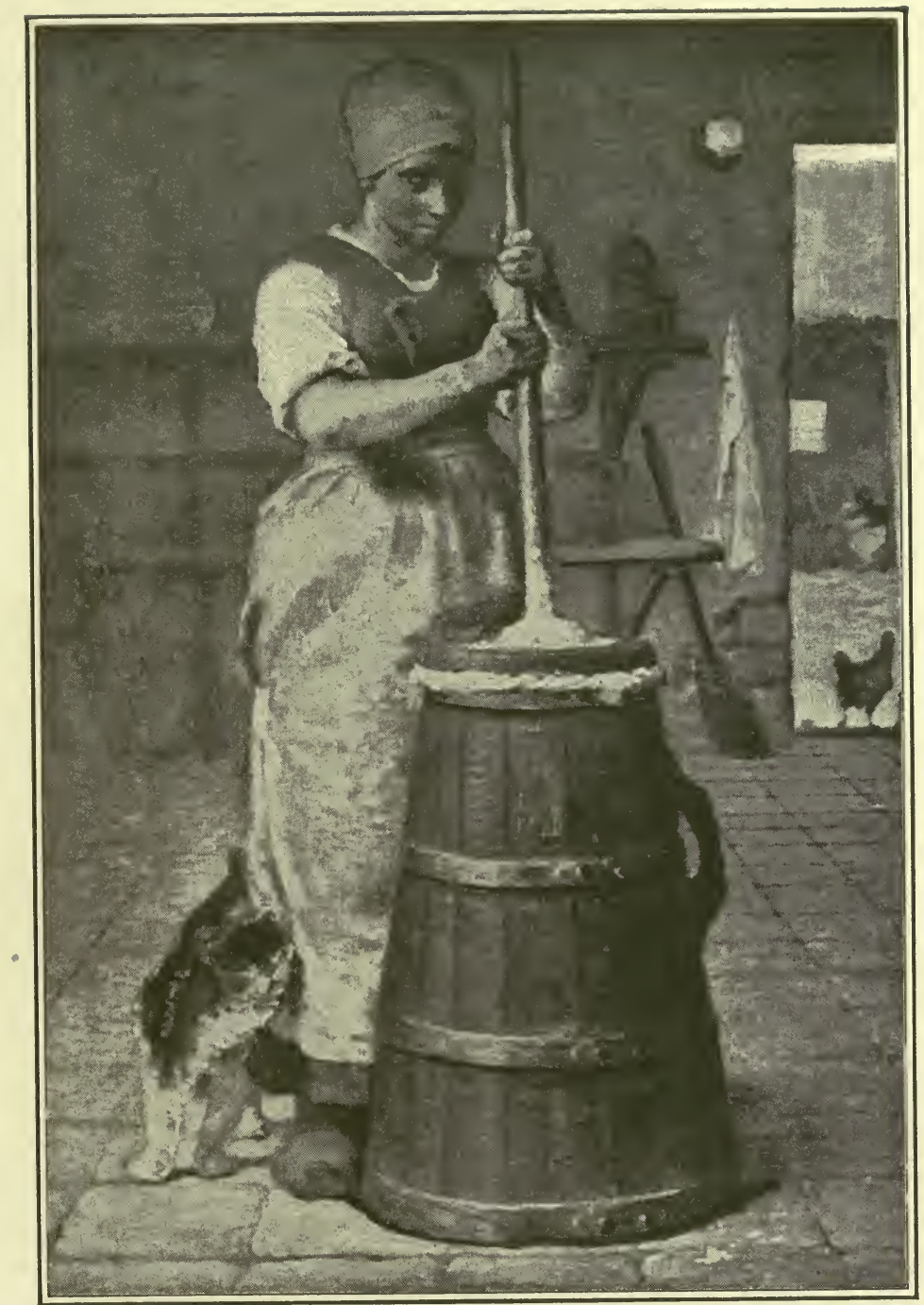

From a painting by Jean François Millet A WOMAN CHURNING 


\section{Lesson I 47 \\ THE BOY AND THE RIVER A Fable}

A LITTLE boy was once sent to market by his A mother to sell butter and cheese.

On the way he came to a swift-flowing river. The boy stopped and looked at the water as it ran swiftly by on its way to the great sea. "Well," said he to himself, "there is no bridge here, nor any boat in sight, so I will wait until the water has all run by." Saying this, he laid himself down in the shade on the mossy bank to wait until the river ran by.

The morning passed away and noon came; still the river ran on, and the boy waited. The afternoon came and went and the golden sun sank down in the west, but the river still ran on, and the boy waited. Late at night he went home to his mother with the butter and cheese.

"How is this, my son?" she exclaimed in surprise. "Why have you brought all the butter and cheese home again?"

"Mother," replied the boy, "yonder there is a 
river that has been running all day long, and I stayed until now, waiting for it to run by, yet it is still running."

"Ah, my son," said his mother, "you will never, never sell your butter and cheese if you wait till the river has run by."

Write the story of "The Boy and the River."

\section{Lesson I 48}

\section{RAIN IN SUMMER}

OW beautiful is the rain! In the broad and fiery street, In the narrow lane, How beautiful is the rain!

How it clatters along the roofs, Like the tramp of hoofs! How it gushes and struggles out,

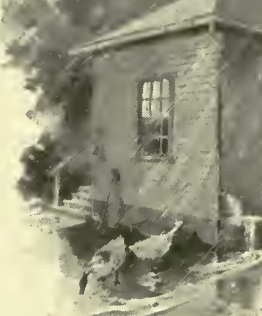
From the throat of the overflowing spout!

Across the window-pane It pours and pours ; 
And swift and wide

With a muddy tide,

Like a river down the gutter roars

The rain, the welcome rain!

The sick man from his chamber looks

At the twisted brooks;

He can feel the cool

Breath of each little pool;

His fevered brain

Grows calm again,

And he breathes a blessing on the rain.

From the neighboring school

Come the boys,

With more than their wonted noise

And commotion;

And down the wet streets

Sail their mimic fleets,

Till the treacherous pool

Ingulfs them in its whirling

And turbulent ocean.

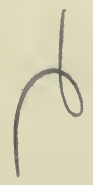

In the country, on every side,

Where far and wide,

Like a leopard's tawny and spotted hide, 
Stretches the plain;

To the dry grass and the drier grain

How welcome is the rain!

* $\quad * \quad *$

-Henry W. Longfellow.

With what cxclamation does this pocm begin?

Give as many reasons as you can for calling the rain "beautiful." Tell about sounds you have heard the rain make.

What becomes of the rain that falls on the roofs and streets?

If you have ever played in the water after a rain storm, tell about it. What happens to the brooks after a rain?

What welcomes the rain in the country?

Illustrate the fifth stanza by a picture.

Fall, gentle rain, in blessed, brimming drops; Cool with thy kiss the city's burning streets; Moisten the meadows where the hot sun beats, And fali refreshing on the thirsty crops.

-From "Songs of the Soil," by Frank L. Stanton.

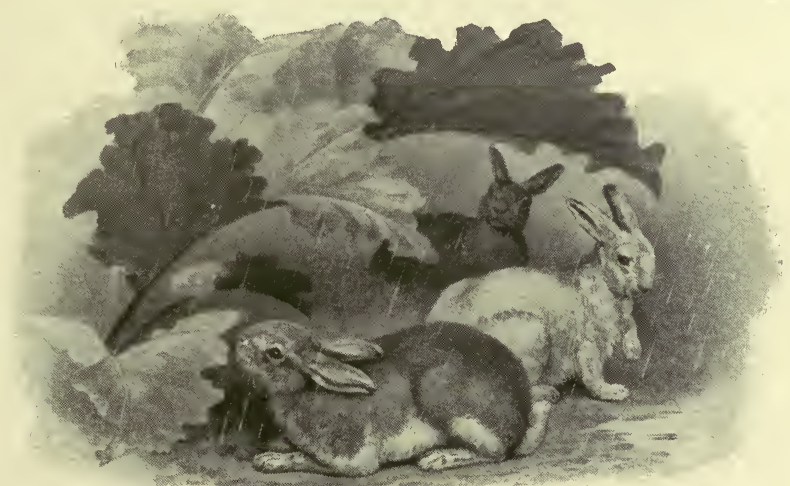




\section{Language Through Nature}

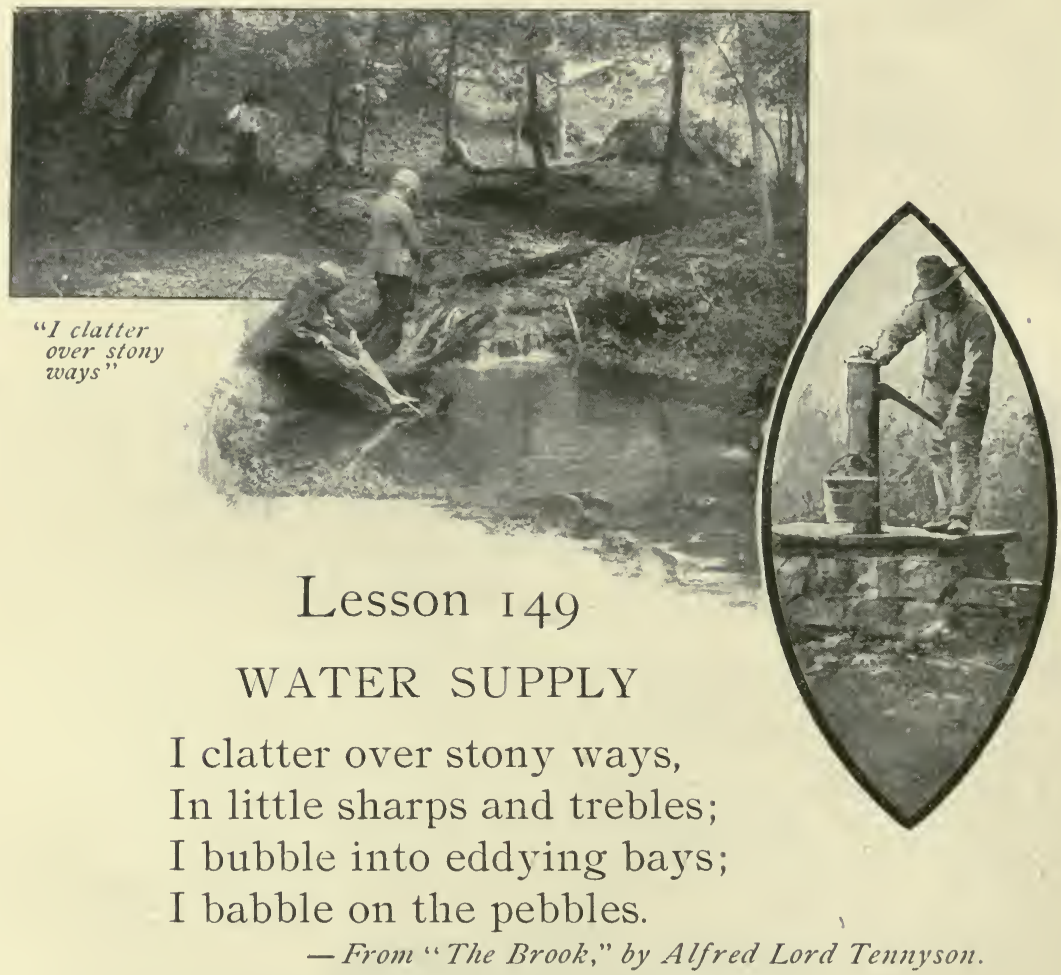

Mention different purposes for which water is used.

Describe the ways in which rain water is caught and stored.

Name other places from which water is obtained.

Tell about ways in which water is brought from distant sources to places where it is needed.

How is water obtained from deep places in the earth?

Make pictures to illustrate ways in which people obtain water. Write a paper telling the source of the water supply in your home and describing the way' in awhich you get it. 


\section{Lesson I 50 \\ JUNE DAYS}

ND what is so rare as a day in June?

Then, if ever come perfect days;

Then Heaven tries earth if it be in tune,

And over it softly her warm ear lays;

Whether we look, or whether we listen,

We hear life murmur, or see it glisten;

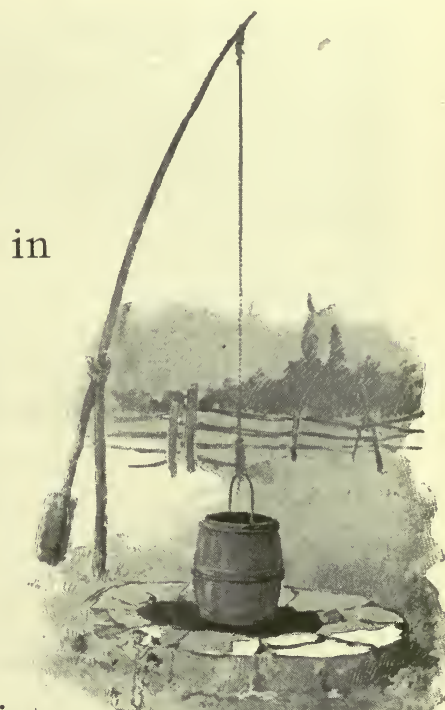
* $\quad * \quad * \quad * \quad * \quad *$

We sit in the warm shade and feel right well How the sap creeps up and the blossoms swell; We may shut our eyes, but we cannot help knowing That skies are clear and grass is growing; The breeze comes whispering in our ear, That dandelions are blossoming near,

That maize has sprouted, that streams are flowing,

That the river is bluer than the sky, That the robin is plastering his house hard by; 


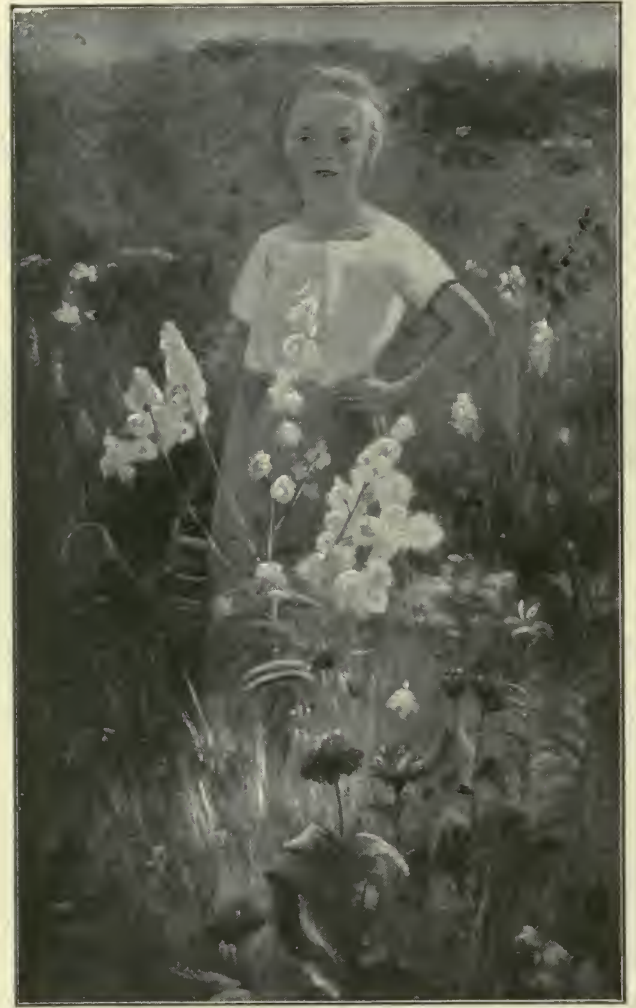

From a painting by E. L. Alkan-Levy

"Whether we look, or whether we listen. We hear life murmur, or see it glisten."
And if the breeze kept the good news back,

For other couriers we should not lack;

We could guess it all by yon heifer's lowing,-

And hark! how clear bold chanticleer,

Warmed with the new wine of the year,

Tells all in his lusty crowing!

Joy comes, grief goes, we know not how;

Everything is happy now,

Everything is upward striving;

'Tis as easy now for the heart to be true

As for grass to be green or skies to be blue,-

'Tis the natural way of living.

-From "The Vision of Sir Launfal," by James Russell Lowell. 
What kind of a June day does this poem describe?

Tell what we like to do on such days.

Mention some things that we "know," even though "we may shut our eyes."

What is it that tells us about these things?

In what way do the "other couriers" or messengers bring the news of spring days?

What is it that makes everything happy on such days?

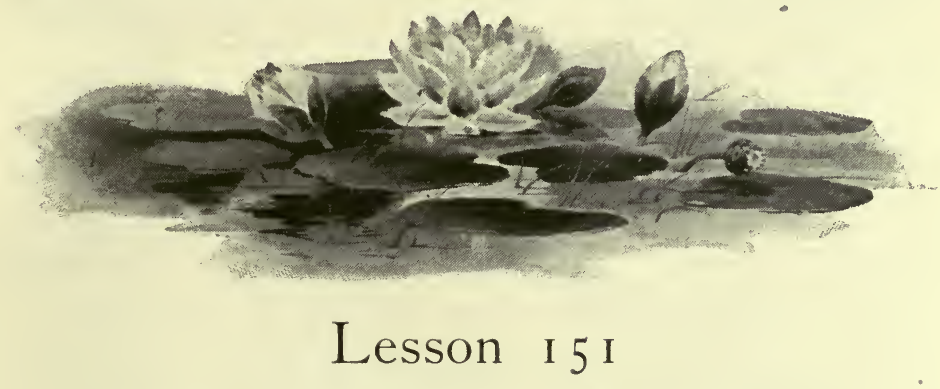

\section{THE GLADNESS OF NATURE}

S this a time to be cloudy and sad,

When our mother Nature laughs around;

When even the deep blue heavens look glad,

And gladness breathes from the blossoming ground?

There are notes of joy from the hang-bird and wren,

And the gossip of swallows through all the sky, The ground-squirrel gayly chirps by his den, And the wilding bee hums merrily by. 
The clouds are at play in the azure space And their shadows at play on the bright-green vale,

And here they stretch to the frolic chase, And there they roll on the easy gale.

There's a dance of leaves in that aspen bower, There's a titter of winds in that beechen tree, There's a smile on the fruit, and a smile on the flower,

And a laugh from the brook that runs to the sea.

And look at the broad-faced sun, how he smiles

On the dewy earth that smiles in his ray,

On the leaping waters and gay young isles;

Ay, look, and he'1l smile thy gloom away.

-William Cullen Bryant.

You may copy and learn this poem.

\section{Lesson I 52}

\section{A PICTURE STUDY}

Write about this picture, telling:

First, what it is called.

Second, what you see in the picture.

Third, what season it tells about.

Fourth, what you like best about the picture.

Fiftll, the name of the artist. 


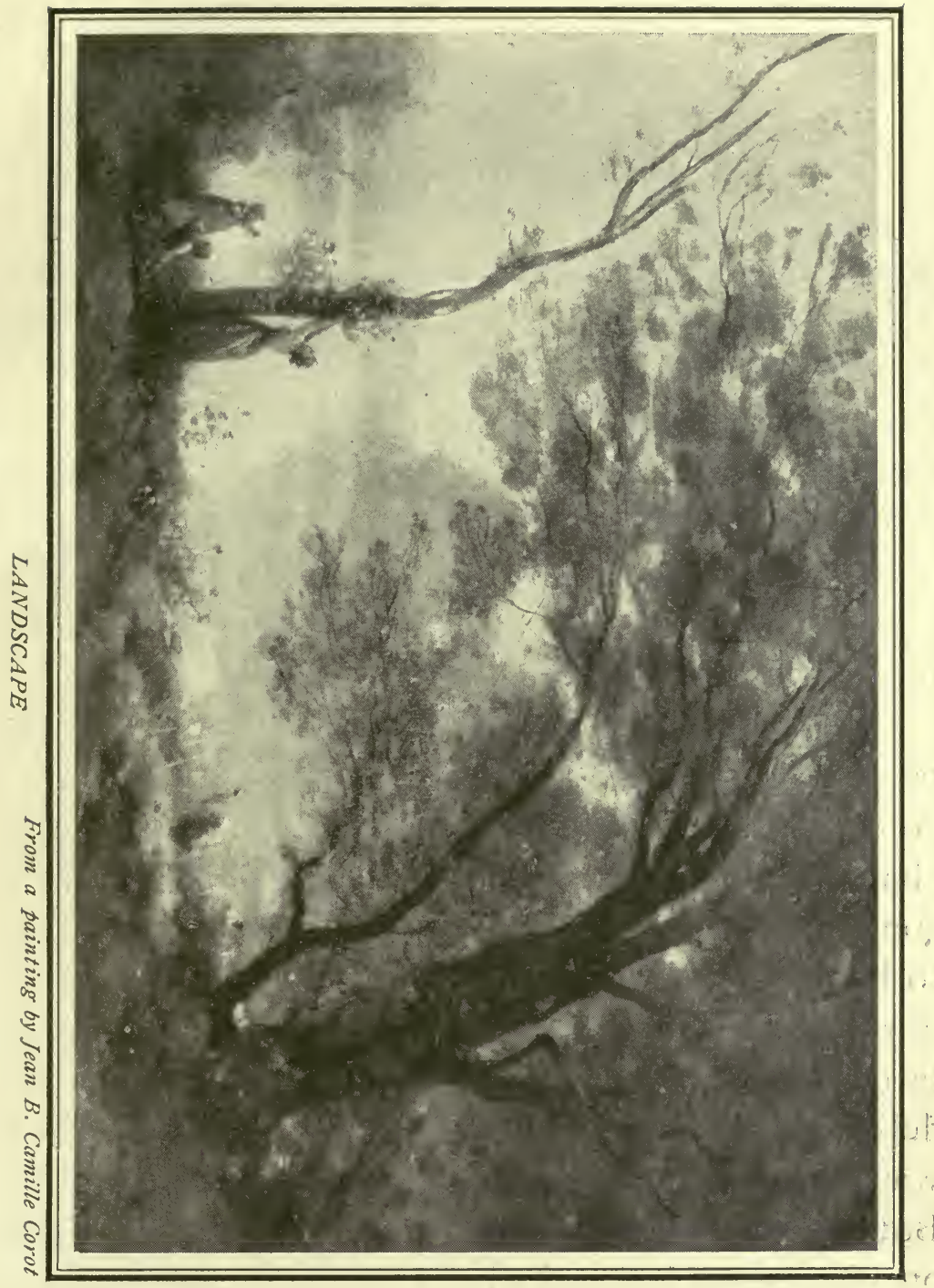




\section{Language Through Nature}

\section{Lesson I 53}

\section{JEAN BAPTISTE CAMILLE COROT}

MORE than a hundred years ago there lived a M French boy whose name was Jean Baptiste Camille Corot. This boy had wonderfully observing eyes. He saw the most beautiful pictures in the soft, gray mists which rose from lake and river, in the gently swaying branches of the trees, and in the morning and evening skies. He longed to put these pictures upon canvas, and begged his father to allow him to become an artist.

But his father said, "Nonsense, I will have no painter in my family. You must go to work." And accordingly Camille was sent to a woolen merchant to learn to sell cloth. Poor Camille! how could he sell cloth while he longed with all his heart to be an artist? He was unhappy and very unsuccessful. At last he was allowed to give up the work he did so badly, and to learn to paint pictures. How delighted Camille was, and how industrious! but it was long, long years before he became a great artist. But all this time he was not discouraged; he plodded on, singing as he worked. 
When he finally became famous he was very kind to poor young artists. They all loved him, and called him "Good Papa Corot."

Corot delighted to paint in the early morning. Long before sunrise he used to be up and out of doors. Dressed in an old blue blouse, a big hat on his head and a great umbrella under his arm, he was ready for work. As he went along the country road he laughed and sang. He talked to the birds, the butterflies, and the trees. He called out, "Is it for me you are singing, little birds? Well, this is fine."

Corot loved nature, and he loved to paint. His pictures show us lakes and woods and meadows. As we look we seem to see the sunshine, and to feel the cool, sweet air of morning as it gently stirs the branches of the trees, and we catch something of the beauty that is in "earth and sky and sea."

Tell about Corot's life in your own words.

Art is a wonderful expression through stone, or canvas, or musical sound, of the deepest and simplest attributes of our nature.

- Ralph Waldo Emerson.

"What is the message of Art? To teach men the knowledge of Beauty. What is Beauty? The heart of God." 


\section{Language Through Nature}

\section{Lesson I 54 \\ THE VOICES OF NATURE A Hyth of Finland}

\ANEMUINE, the god of song, dwelt on the Hill of Taara. But he grew tired of living in Finland and of his beautiful hill, so he sent word for all things to come to him to receive the language they were to speak before he went away to his palace in the sky. As they gathered around

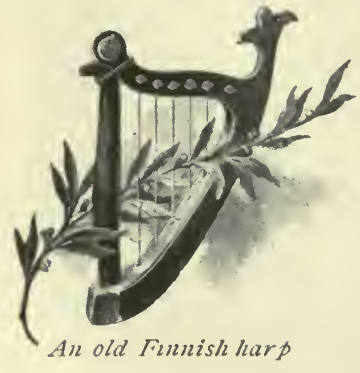
him, he opened. his lips and sang so sweetly, so softly, that the murmur of his harp strings seemed almost harsh as compared with the music of his rich voice.

The wandering winds who listened afar off caught and remembered only the loudest tones. The sacred stream that flows so softly around the Hill of Taara chose for its language the rustling of the silken garments which moved upon his shoulders as he played.

The listening trees of the forest heard the rushing of his flowing mantle as he descended from his 
throne on the crest of the hill; and ever since, this has been the language of the tree-tops. If one will sit on the mossy bank of a little brook near by a full-leaved forest, he may even now fancy that Vanemuine is come again to earth.

Some of the larger creatures took up the deeper tones of the heavy harp strings, and their language is now full of these sounds. Others loved the melody of the lighter strings, and this softer music is ever in their voices.

In his great joy Vanemuine sang songs never before heard on the earth, and the listening nightingale caught their meaning, never to forget. When you hear the nightingale pour out its song in the dusk of evening hours, you hear an echo of the song the nightingale heard upon the Hill of Taara.

Vanemuine sang of love and of the beautiful springtime. The happy lark heard and understood, and the sweetest tones of the song she sings over and over with each returning morning. As she soars higher and higher into the clear air, she sings her song, trying to tell the whole world of the love and beauty of which she heard so long ago.

While everything else was being made so happy, 
the poor fishes were having a sad time. They could not leave the water to go to the Hill of Taara, but they stretched their heads out of the brooks and rivers to their very eyes, yet kept their ears under. So they saw Vanemuine, the song-god, move his lips, but heard nothing, and they did as he did and made no sound. To this day the poor, dumb fishes move their lips, but speak no language.

Only the men and women who stood close around the Hill of Taara understood everything that was sung. That is why human voices more than any others can thrill us and make us see the beautiful and true.

Vanemuine sang of the glory of heaven and of the beauty of earth. He sang of the flowing waters and of the rustling leaves. He sang of the joys and the sorrows that come to all people, to children and parents, to the rich and to the poor. If we listen to the songs sung to-day, with open ears and expectant hearts, we may hear all that Vanemuine sang so long ago upon the Hill of Taara.

When Vanemuine's songs had been heard by all the world, he rose on the wings of the winds and went far into cloudland to his golden palace in the 
sky. There he still sings his wonderful songs for those who are greater than mankind.

To this very day the people of Finland think they can sometimes hear Vanemuine's voice when the forest trees sigh in the wind, or the water in the river softly laps against its rocky shore.

Perhaps - who knows? - we may hear him, too, if we listen well!

$$
\text { -From "Classic Myths," by Mary Catherine Judd. }
$$

" The foxest tree figh in the wind, the watex

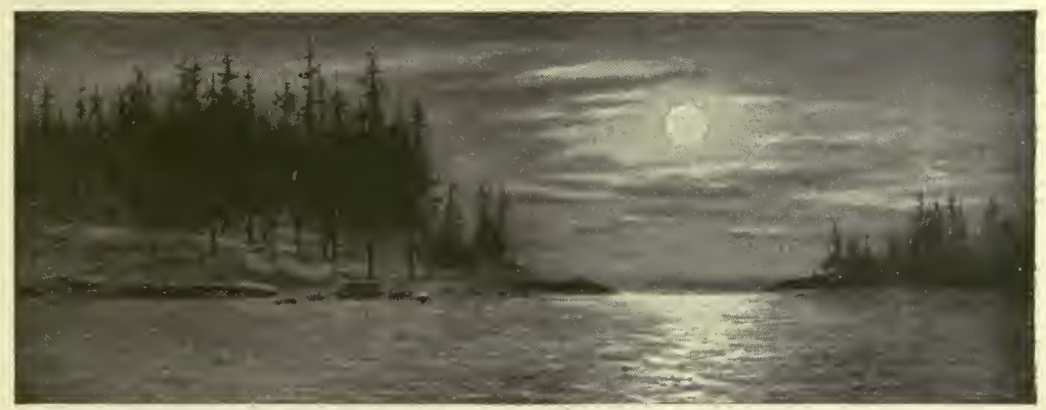

in the xivex oftly lap againet it rocky shoxe" 


\section{A PRONOUNCING INDEX}

The diacritical markings in this list agree with the latesi edition of Webster's International Dictionary.

adobe (å d $\left.\delta^{\prime} b a\right)$

Alkan-Levy

(ăl kăn'-lē vy)

Al'achne (ả răk' nē)

artificial (är tř fřsh' ăl)

Athena (à thē' näi)

Aurora (ạ $u$ rō' rä)

bè guīle'

bevies (běv' $\mathrm{Iz})$

Björnson, Björnstjerne Martinius (byẽrn'sǒn, byẽrn'shěr' ně mär třn' î ǔs)

Bologua (bō lōn' yä)

Bonleur, Rosa

(bǒ' nur')

Boughton (bō' tǒn)

braw uy (brann' y̆)

Bruzzi (brụ tš́)

Buonarroti, Michael Angelo

(b⿳亠丷厂 ō' när rŏt' ee, mi' ka हैl ăn' jầ lō)

Carrara, (kär' rä́' rä)

chinticleer

$$
\text { (chăn' tĩ klēr') }
$$

Cheemaun (chē' mạn)

Cherbourg' (shěr' burg)

Corot, Jean Baptiste Camille (kō rō', zhŏn bä tēst')

Dagnan-Bouveret, Pascal Adolple

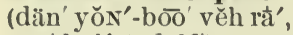
päs' käl' ä dạlf')

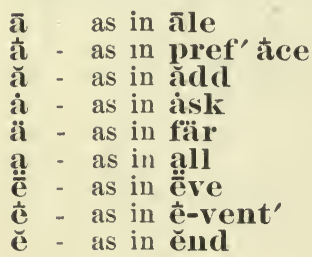

Daubigny, Charles François (dō bēn y y', shärlz frŏn' swä')

eclipse (’̀ klı̄ps')

excavated (ěks' kả vā' těd)

Geezis (gē' ž̃) gentian (jěn' shăn)

Gitche Gumee (g`̌t' chē gū' mē)

harpsichord

Hiawatlia (härp' sĩ kôrd) Hyacintlh (hĩ' à sǐnth) Jā' 1 ŭs

Kā'bē yŭu

Kả bĭb ō nōk' kà

luscious (lǔsh' ŭs)

Matterhorn

Mauve, Anton (mōv, än' tōx's)

mè mồ rŏ ălı

MI' dăs

Millet, Jean Francois (mèt yà', zhŏn frǒn' swä')

MǏn' ně hä' hä

Mǐsh' ě-Mōw'kä

Mŏn dä' mǐn

Mudjekeewis

(mŭd jē kē' wiss)

$\tilde{\mathbf{e}}$ - as in $\mathbf{l} \tilde{\mathbf{e}} \mathbf{r}$

I - as in ice

$\mathbf{1}$ - as in 1-de' a

1 - as in $\mathbf{1 1}$

o - as in old

o - as in ŏdd

$\hat{\mathbf{o}}$ - as in lôrd

$\overline{\mathbf{n}}$ - as in İse

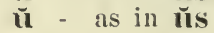

När cǐs'sŭs

Navajo (nä' vä hō)

Nō kō' mis

Norwegian (nǒr wē jŭ ăn

Olympus (ō lĭm' pŭs)

$\overline{00 Z} Z^{\prime}$ 111

Opechee (ō pē' chee)

Ovaissa (ō wãis' sà)

poising (poiz' Ing)

Reni, Guido (rā' nē, g'wēe' do) rhythmic (r'̌th' mǐk)

Scřl' là

sedges (sěj' ěz)

Sliạw ơn dā' see

Shelley, Percy

Bysshlıe (shěl' Ĭ, břsh) Sís'tine

Svěnd' sěn, Svěnd

Taara ( $\tan ^{\prime}$ rả)

Taquamenaw

trěach' ẽr oŭs

Troyon, Constant

(trwä' yơ $x^{\prime}$ )

Vă nĕm’ n̄ine (ēu)

va' rŭ è ga' těd

Vulcan (vŭl' kăn)

Wa băs' sō

Wặ'bŭแ

Zögel (zẽr' gel)

11 - as in rucle

$\ddot{y}$ - as in pitt'

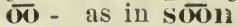

N represents the French nasal sound as in ensenuble(äx'säN' b']). Silent letters are italicized. 


\section{LIGHTS TO LITERATURE A SERIES OF READERS}

\section{EIGHT=BOOK SERIES BY GRADES}

THE PLAN OF THE BOOKS

THE HOLTON PRIMER is the first book of the series, and a primer throughout. The lessons are short, dramatic, and interesting. They deal with the real things of childlife. Illustrated. Cloth, ir i pages; 25 cents.

BOOK ONE. Stories of growing things, of games, and of events which lead the pupil to self-expression. Illustrated. Cloth, i 27 pages; 25 cents.

BOOK TWO. Stories of children's pets, of birds and flowers, and the little interests of a child's world. Illustrated. Cloth, r66 pages; 36 cents.

BOOK THREE. Stories of kindly fairies, of Greek and Indian myths, of the deeds of heroes; selections from Longfellow, Emerson, Wordsworth, Coleridge, Stevenson, and many others. Illustrated. Cloth, 208 pages; 40 cents.

BOOK FOUR. Selections from children's classics; extracts from the works of Hans Andersen, Joel Chandler Harris, Bryant, Whittier, Longfellow, Thomas Hughes, Lewis Carroll, Lowell, and many others. Illustrated. Cloth, 208 pages, 40 cents.

BOOK FIVE. Stories of adventure, heroic deeds, and chivalrous action, from Hawthorne, Kingsley, Defoe, Holmes, Whittier, Howells, Riley, Burroughs, Dickens, and many others. Cloth, 208 pages; 40 cents.

$\boldsymbol{B O O K} \boldsymbol{S I X}$. Stories of national heroes and historical events, descriptions of nature and inventions, by Franklin, Grant, Holmes, Irving, Thoreau, Wordsworth, Washington, Warner, Stevenson, Lowell, Greeley, Burns, Ruskin, Scott, Audubon, and Dickens. Cloth, 24 o pages; 45 cents.

$\boldsymbol{B O O K}$ SE VEN. Complete American and British masterpieces, from Lincoln, Webster, Washington, Franklin, Poe, Irving, Lamb, Macaulay, Whittier, Longfellow, Tennyson, and O'Reilly. Cloth, 266 pages; 50 cents.

BOOK EIGHT. Complete masterpieces from Burroughs, Goldsmith, Hawthorne, Gray, Burns, Lowell, Holmes, Shelley, Wordsworth, Browning, Emerson, Dr. Brown, and Shakspere. Cloth, 272 pages; 50 cents.

\section{FIVE=BOOK SERIES}

\section{THE PLAN OF THE BOOKS}

THE HOLTON PRIMER. It is a primer throughout, and is a definite preparation for Book l. Action lessons are frequent Fully illustrated in half-tone with fourteen pages in three colors. Cloth, irr pages; 25 cents.

BOOK ONE. Stories which lead the pupil to self-expression. Fully illustrated in halftone, with twenty-four pages in color. Cloth, 127 pages; 25 cents.

BOOK $\boldsymbol{T} \boldsymbol{W}$ O. Fully illustrated in half-tone. Cloth, 166 pages; 36 cents.

BOOK THREE. Stories of kindly fairies, of Greek and Indian myths, of the deeds of heroes; and numerous selections from Longfellow, Emerson, Wordsworth, Coleridge, Stevenson, and many others. Twenty-two full-page illustrations in half-tone. Cloth, 317 pages; 48 cents.

BOOK FOUR. Selections which appeal to their sympathies and draw out their powers of observation; stories of adventure, heroic deeds, and chivalrous action; from the works of Hans Andersen, Joel Chandier Harris, Hawthorne, Kingsley, Defoe, Thomas Hughes, Lewis Carroll, and many others. Fully illustrated in half-tone. Cloth, 4II pages; 60 cents.

$\boldsymbol{B O O K} \boldsymbol{F} \boldsymbol{I V E}$. Stories of national heroes and historical events, descriptions of nature and inventions, as found in selections from Holmes, Whitter, Howells, Riley, Franklin, Grant, Irving, Thoreau, Wordsworth, W ashington, Stevenson, Burroughs, Dickens, and many others, with portrait and biographical sketch of each author. Cloth, 506 pages; 90 cents.

$$
\begin{gathered}
\text { RAND, McNALLY \& } \text { CO., Educational Publishers } \\
\text { Chicago }
\end{gathered}
$$




\section{SUPPLEMENTARY READERS}

CLASSIC MYTHS, by Mary Catherine Judd, Principal of the 1.incoln School, Minneapolis. With 43 illustrations. Cloth, 208 pages; 35 cents. For the third and fourth grades.

FOUR OLD GREEKS, by Jennie Hall, of the Francis W. Parker School, Chicago. With 39 illustrations from Greek sources, by Raymond Perry. Cloth, 224 pages; 35 cents. For the second and third grades.

CHILD STORIES FROM THE MASTERS, by Maud Menefee. With to illustrations in sepia. Cloth, rou pages; 30 cents. For the third and fourth grades.

THE HOLTON PRIMER (Lights to Literature series), by M. Adelaide Holton, Supervisor of Primary Schools, Minneapolis, Minn. With 69 half-tone illustrations, ${ }_{4} 4$ pages in color, and decorative end papers. Cloth III pages; 25 cents.

THE SUNBONNET BABIES" PRIMER, by Eulalie Osgood Grover. With 86 illustrations in four colors by Miss Corbett, "The Mother of the Sunbonnet Babies." Cloth, r ro pages; 40 cents.

A CHILD'S GARDEN OF VERSES, by Robert Louis Stevenson. With 6r illustrations by Miss Mars and Miss Squire. Cloth, 93 pages; 50 cents. For the primary grades.

NORSE STORIES, by Hamilton Wright Mabie. Edited by Katharine Lee Bates, Professor of English Literature in Wellesley College. Illustrated with ro full-page drawings by George Wright. Cloth, 304 pages; 40 cents. For the fourth and fifth grades.

ESKIMO STORIES, by Mary E. E. Smith, of the Lewis-Champun School, Ciricago. With 93 illustrations in half-tone. Cloth, 189 pages; 35 cents. For the first and second grades.

VIKING GALES, by Jennie Hall, of the Francis W. Parker School, Chicago. Illustrated. Cloth, 207 pages ; 35 cents. For the fourth and fifth grades.

THE STORY OF ACHILLES AND HECTOR, adapted from the lliad of Homer, by Agnes Cook Gale. Illustrated. For the fourth and fifth grades.

KING ARTHUR AND HIS KNIGHTS, by Maude L. Radford, Instructor in English in the University of Chicago. Illustrated. For the fifth and six.'h grades.

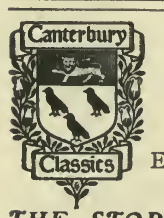

\section{Che Canterbury Classics}

A New Series of Supplementary Readers for all Grades

Edited under the general supervision of KATHARINE LEE BATES,

Professor of English Literature in Wellesley College

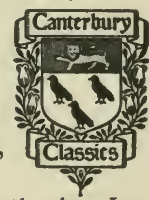

THE STORY OF THE CANTERBURY PILGRIMS. Retold by Katharine lee Bates, Professor of English Literature in Welleslev College. Illustrated.

RAB AND HIS FRIENDS, AND OTHER DOG STORIES, by Dr. John Brown. Edited by Charles W. French, Principal of the Hyde Park High School, Chicago. Illustrated with a portrait of Doctor Brown, 6 full-page and 16 text drawings by Angus MacDonall, and 5 reproductions of original sketches by the author. Cloth, 150 pages; 25 cents.

THE GOLD BUG, by Edgar Allan Poe. Edited by Theda Gildemeister, Training Teacher in the State Normal School, Winona, Minn. Illustrated with the Zolnay bust of Poe as Frontispiece, a map of Sullivan's Island, and 6 full-page drawings by G. C. Widney. Cloth, iri pages; 25 cents.

THE CRICKET ON THE HEARTH, by Charles Dickens. Edited by George B. Aiton, State Inspector of High Schools for Minnesota. Illustrated. Cloth, 176 pages, 30 cents.

THE KING OF THE GOLDEN RIVER, by John Ruskin. Edited by Katharine Lee Bates, Professor of English Literuture in Wellesley College. Illustrated. 20 cents.

THE DOG OF FLANDERS, by Louise de la Ramèe. Edited by Rose Swart, Supervisor of Methods in the State Normal School, Oshkosh, Wis. Illustrated.

THE STORY OF A SHORT LIFE, by Julia H. Ewing. Edited by Sarah E. Brooks, Supervisor of Primary Schools, St. Paul, Minn. Illustrated.

THE LADY OF THE LAKE, by Sir Walter Scott. Edited by F. A. Barbotr, Professor of En glish in the State Normal College, Ypsilanti, Mich. Illustrated.

THE CHRISTMAS CAROL, by Charles Dickens. Edited by Katherine Gill, Instructor in English in the State Normal School, Charleston, Ill. Illustrated.

RAND, McNally \& CO., Educational Publishers

Chicago New York Iondon 




\section{YC 49898}

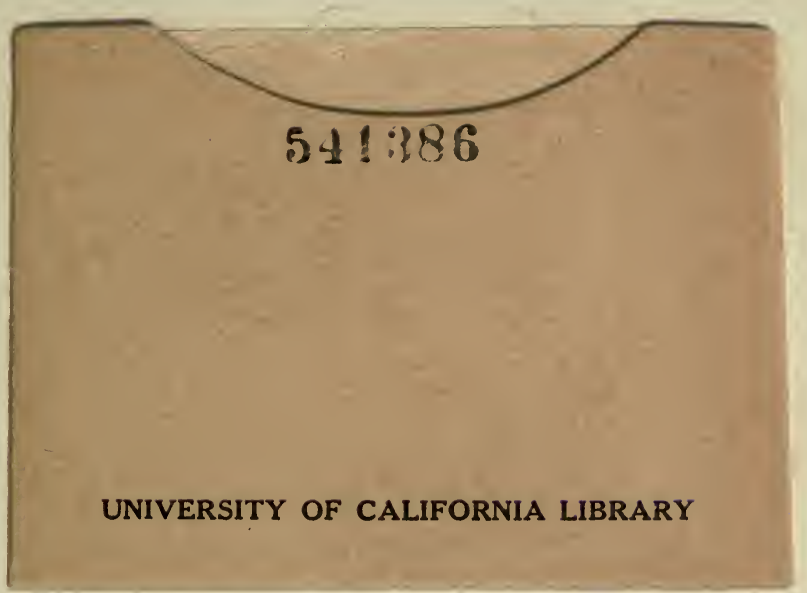


